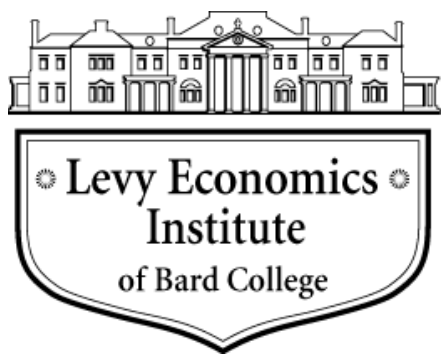

Working Paper No. 984

\title{
The Empirics of Long-Term Mexican Government Bond Yields
}

\author{
by \\ Tanweer Akram \\ Wells Fargo \\ and \\ Syed Al-Helal Uddin \\ College of Saint Benedict and Saint John's University
}

February 2021

The Levy Economics Institute Working Paper Collection presents research in progress by Levy Institute scholars and conference participants. The purpose of the series is to disseminate ideas to and elicit comments from academics and professionals.

Levy Economics Institute of Bard College, founded in 1986, is a nonprofit, nonpartisan, independently funded research organization devoted to public service. Through scholarship and economic research it generates viable, effective public policy responses to important economic problems that profoundly affect the quality of life in the United States and abroad.

Levy Economics Institute

P.O. Box 5000

Annandale-on-Hudson, NY 12504-5000

http://www.levyinstitute.org

Copyright (C) Levy Economics Institute 2021 All rights reserved

ISSN 1547-366X 


\begin{abstract}
This paper presents empirical models of Mexican government bond (MGB) yields based on monthly macroeconomic data. The current short-term interest rate has a decisive influence on MGB yields, after controlling for inflation and growth in industrial production. John Maynard Keynes claimed that government bond yields move in lockstep with the short-term interest rate. The models presented in the paper show that Keynes's claim holds for MGB yields. This has important policy implications for Mexico. The empirical findings of the paper are also relevant for ongoing debates in macroeconomics.
\end{abstract}

KEYWORDS: Mexican Government Bonds; Long-Term Interest Rate; Short-Term Interest Rate; Monetary Policy; Banco de México (BdM); Banxico

JEL CLASSIFICATIONS: E43; E50; E58; E60; G10; G12 


\section{INTRODUCTION}

The central bank's actions have a decisive influence on the long-term interest rate on government bonds, according to John Maynard Keynes (1930). Keynes held that the longterm interest rate mostly moves in lockstep with the short-term interest rate, which in turn depends primarily on the central bank's policy rate. This paper models the relationship between the short-term interest rate and the long-term interest rate in Mexico using monthly data. It shows that the short-term interest rate plays an important role in the dynamics of the long-term interest rate on Mexican government bonds (MGBs) of various maturity tenors after controlling for macroeconomic variables, such as the rate of inflation and the growth of industrial production. The empirical models presented here demonstrate that the Keynesian perspective provides useful insights about the dynamics of long-term MGB yields.

\section{Relationship to the Literature}

Keynes's views on the short-term interest rate's influence on the long-term interest rate have been empirically modeled in recent years. The Keynesian perspective on modeling government bond yields has been applied mostly to advanced economies, such as the United States (Akram and Li 2017, 2020a; Akram and Das 2019b; Levrero and Deleidi 2019), Japan (Akram and Das 2014; Akram and Li 2018, 2019, 2020b, 2020c), the eurozone (Akram and Das 2017), the United Kingdom (Akram and Li, forthcoming), Canada (Akram and Das 2020a; Das and Akram 2020), and Australia (Akram and Das 2020b). However, there are only a limited number of studies on the short-term interest rate's influence on the long-term interest rate for emerging markets. Models of long-term government bonds yields, including studies related to India (Akram and Das 2015, 2017), selected Latin American countries (Simoski 2019), and Brazil (Akram and Uddin 2020), have shown the relationship between the short-term interest rate and the long-term interest rate that Keynes posited appears to also hold in emerging markets. But more studies are required to establish whether this empirical regularity holds in other emerging markets. Thus, it is relevant to ask whether the short-term interest rate influences government bond yields in Mexico.

This paper applies the Keynesian perspective on modeling long-term government bonds yields for Mexico. It also contributes to the ongoing debate between the Keynesian and neoclassical schools of thought concerning government bond yield dynamics. The findings 
obtained from the empirical models estimated in this paper are relevant for macroeconomic debates in Mexico.

The Keynesian school maintains that interest rates have a psychological and sociological foundation in a world characterized by ontological uncertainty (Davidson 2015) in which investors' liquidity preference plays a central role. The Keynesian view is that the long-term interest rate is primarily determined by the central bank's actions, such as the setting of benchmark policy rates, repurchase and reverse repurchase agreements, forward guidance about policy rates, and decisions concerning the central bank's monetary base and balance sheet, intermediated through the short-term interest rates. Drawing on Riefler's (1930) pioneering empirical analysis of the dynamics of the short-term interest rate and the longterm interest rate in the United States in the 1920s and 1930s, Keynes (1930) argued that there is a tight connection between the short-term and long-term interest rates. Keynes (1930, [1936] 2007) provides theoretical arguments for why such a connection exists. Kregel (2011) has encapsulated Keynes's thoughts on interest rates, particularly why investors, driven by herding, animal spirits, and uncertainty, take their cue about long-term government bond yields from the movements of the short-term interest rate. The Keynesian argument has its roots in theoretical arguments in the literature, such as Bindseil (2004), Davidson (2015), Goodheart (1998), Lerner (1943, 1947), Sims (2013), and Tcherneva (2011). It is also based on empirical analysis and policy discussions, such as Malliaropulos and Migiakis (2018), Mattos et al. (2019), Patra et al. (2016), and Sau (2018).

In contrast to the Keynesian school, the neoclassical school maintains that government bonds yields are a function of the demand for and supply of loanable funds. In this view, various exogenous factors, such as government debt and deficits ratios, exert influence on government bonds yields. The neoclassical view of the drivers of the long-term interest rate is the predominant perspective in the existing literature. Recent empirical studies advancing the neoclassical view include Ardagna, Caselli, and Lane (2007), Baldacci and Kumar (2010), Gurber and Kamin (2012), Horioka, Nomoto, and Tera-Hagiwara (2014), Hoshi and Ito (2014), Min et al. (2003), Poghosyan (2014), Reinhart and Rogoff (2019), and Tkačevs and Vilerts (2019). 


\section{Structure of the Paper}

The paper proceeds as follows. Section II presents a Keynesian model of the long-term interest rate. Section III narrates the evolution of MGB yields in the context of macroeconomic developments in Mexico. Section IV introduces the data and the relevant variables used in the behavioral equations in the models. Section V explains the econometric methodology, reports the estimated models, and interprets the findings from these models. Section VI concludes with some reflections on the policy implications of the empirical findings.

\section{A KEYNESIAN MODEL OF THE LONG-TERM INTEREST RATE}

The interest rate model is based on Akram's (2020) interpretation of Keynes's theory of the long-term interest rate, as articulated in his Treatise on Money and General Theory.

The notations used in the model are explained here. The long-term interest rate is $r_{L T}$; the short-term interest rate is $r_{S T}$; and the central bank policy rate is $r_{C B}$. Interest rate volatility is $V \geq 0$; the rate of inflation is $\Pi$; and the growth of industrial production is $Y$. The correlation between the Weiner process, $d z$, and inflation is $\rho_{\Pi}$; and the correlation between the Wiener process, $d z$, and the growth of industrial production is $\rho_{Y}$.

This model is represented in the following equations.

$$
\begin{aligned}
& d r_{L T}=\mu r_{S T} d t+\sqrt{V} r_{S T} d z \\
& d r_{S T}=\alpha\left(r_{C B}-r_{S T}\right) d t+\varepsilon_{t} \\
& d V=\kappa(\theta-V) d t+\sigma \sqrt{V} \sum_{i=1}^{N}(d \Pi+d Y) \\
& d z d \Pi=\rho_{\Pi} d t \\
& d z d \mathrm{Y}=\rho_{Y} d t
\end{aligned}
$$


Equation [1] states that the long-term interest rate follows a geometric Brownian motion that satisfies the above stochastic differential equation. Here, $d z$ is a Weiner process and $\mu$ is the drift term, while $V$ is the volatility of the long-term interest rate. The drift term is a constant.

Equation [2] states that the short-term interest rate, $r_{S T}$, is a mean reverting function of the central bank's policy rate, $r_{C B}$, at a pace of $\alpha$. Here, $\varepsilon_{t}$ is an error term.

Equation [3], the equation for volatility, implies that the volatility of the long-term interest rate, $V$, is a mean reverting to $\theta$ at a rate set by $\kappa$. Here, $\sigma$ is the standard deviation of the volatility and are $d \Pi$ and $d Y$ random variables that, respectively, represent shocks from inflation and the growth of industrial production.

In equation [4], $\rho_{\Pi}$ is the correlation between the Weiner process, $d z$, and inflation, $d \Pi$. In equation [5], $\rho_{Y}$ is the correlation between the Weiner process, $d z$, and the growth of industrial production, $d Y$.

\section{THE EVOLUTION OF THE MEXICAN ECONOMY}

Figure 1 shows the evolution of MGBs' long-term interest rates. Long-term interest rates were quite high in 2004 but began to moderately decline in 2005; they were fairly stable between 2006 to 2007 . Long-term interest rates rose in 2008 but fell notably during the global financial crisis. Long-term interest rates continued to decline in the years immediately after the crisis. These interest rates traded sideways between 2011 and 2016. However, long-term interest rates gradually rose in 2017-18. 
Figure 1. The Evolution of Key Long-term Interest Rates on Mexican Government Bonds, 2004-18

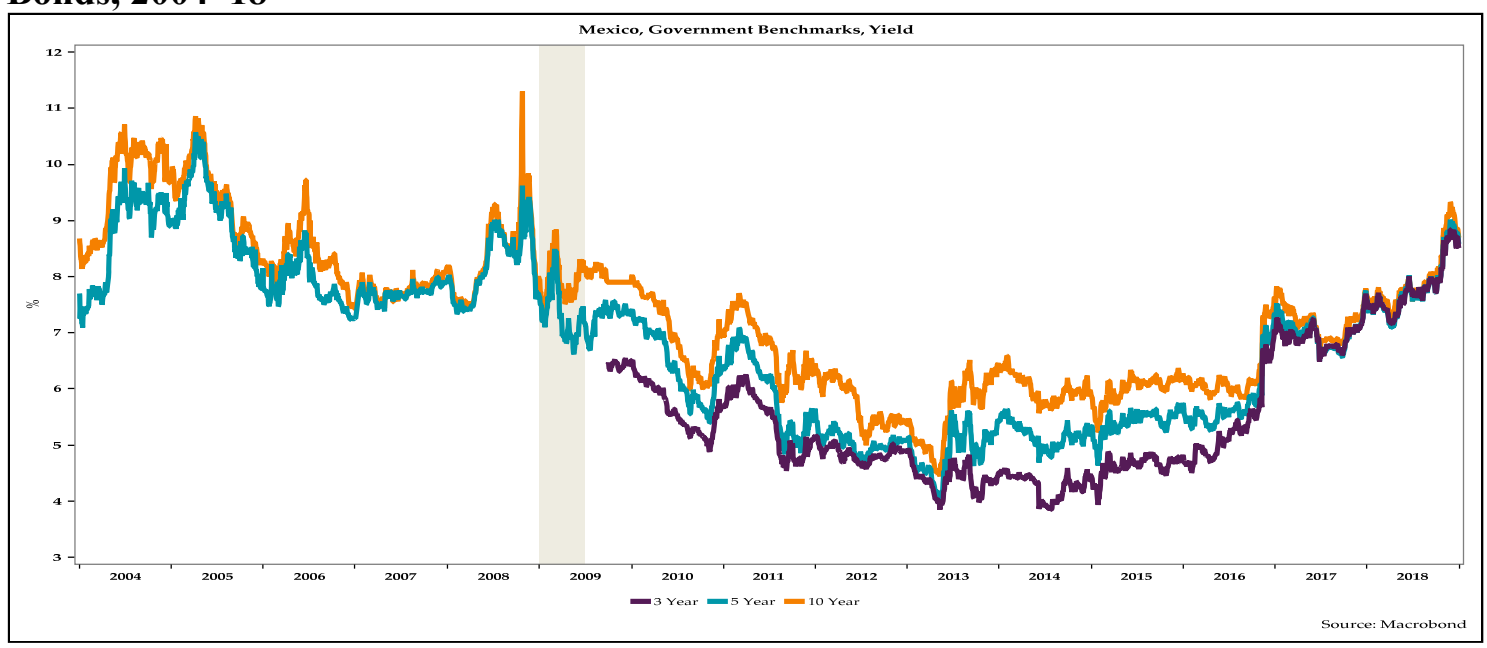

Figure 2 displays the evolution of the short-term interest rate along with the overnight target policy rate set by the Banco de Mexico (BdM), the country's central bank. It shows that the short-term interest rate moves mostly in tandem with the central bank's overnight target policy rate. Short-term interest rates rose in 2004 and early 2015 but declined with the BdM's policy rate cut. Short-term interest rates were steady until the global financial crisis but fell with the onset of the crisis. These rates were stable from mid-2009 to late 2012 but declined moderately between 2012 and late 2015 as the BdM reduced its overnight target policy rate. Short-term interest rates gradually rose from late 2015 to late 2018 in tandem with the steady hikes in BdM's overnight policy target rate during the same period. 
Figure 2. The Evolution of Policy Rates and Short-term Interest Rates in Mexico, 200418

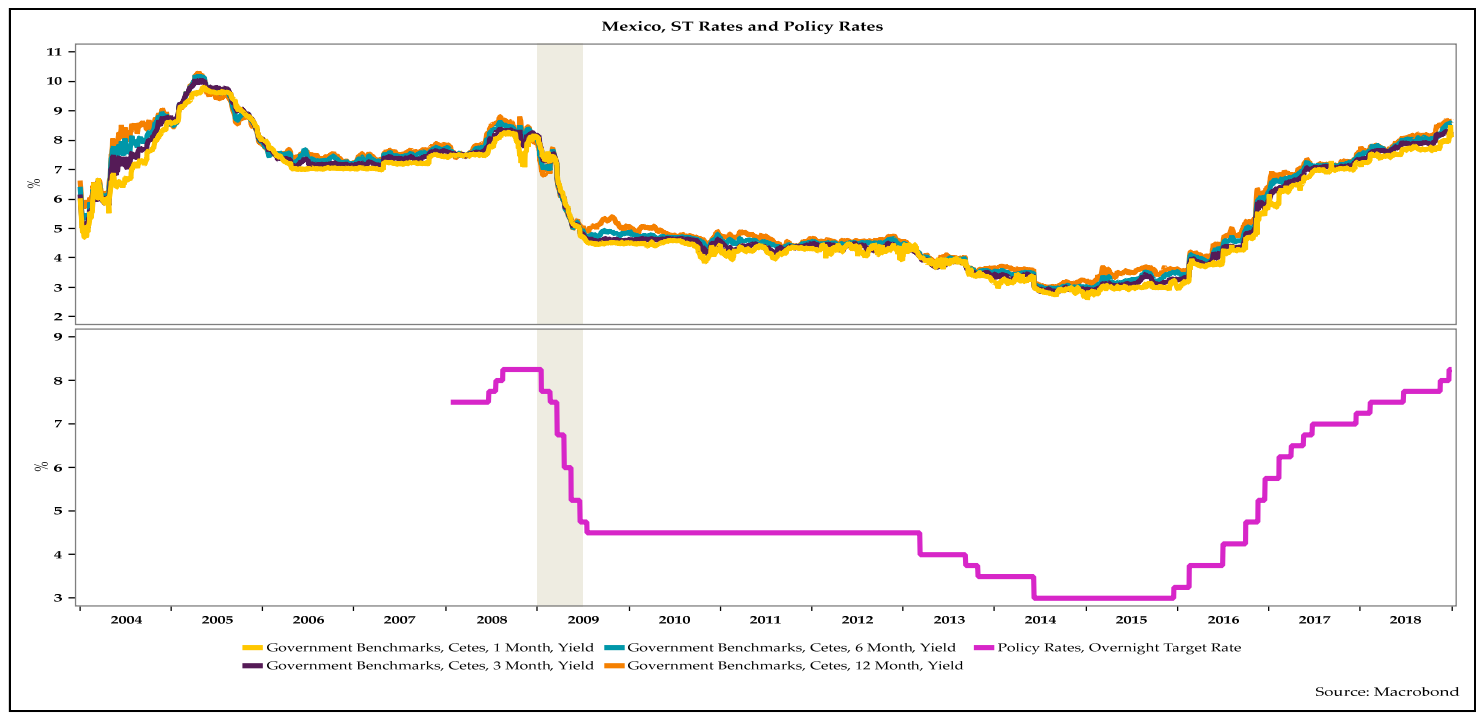

Figure 3 traces the evolution of Mexico's real GDP growth and industrial production.

Economic growth in Mexico was quite moderate during the period. Growth was soft in the years immediately preceding the global financial crisis. During the global financial crisis, the Mexican economy contracted notably. Real GDP growth and the growth in industrial production in Mexico are strongly correlated, as is shown in the scatterplot displayed in figure 4.

Figure 3. The Evolution of Growth in Real GDP and Industrial Production in Mexico, 2004-18

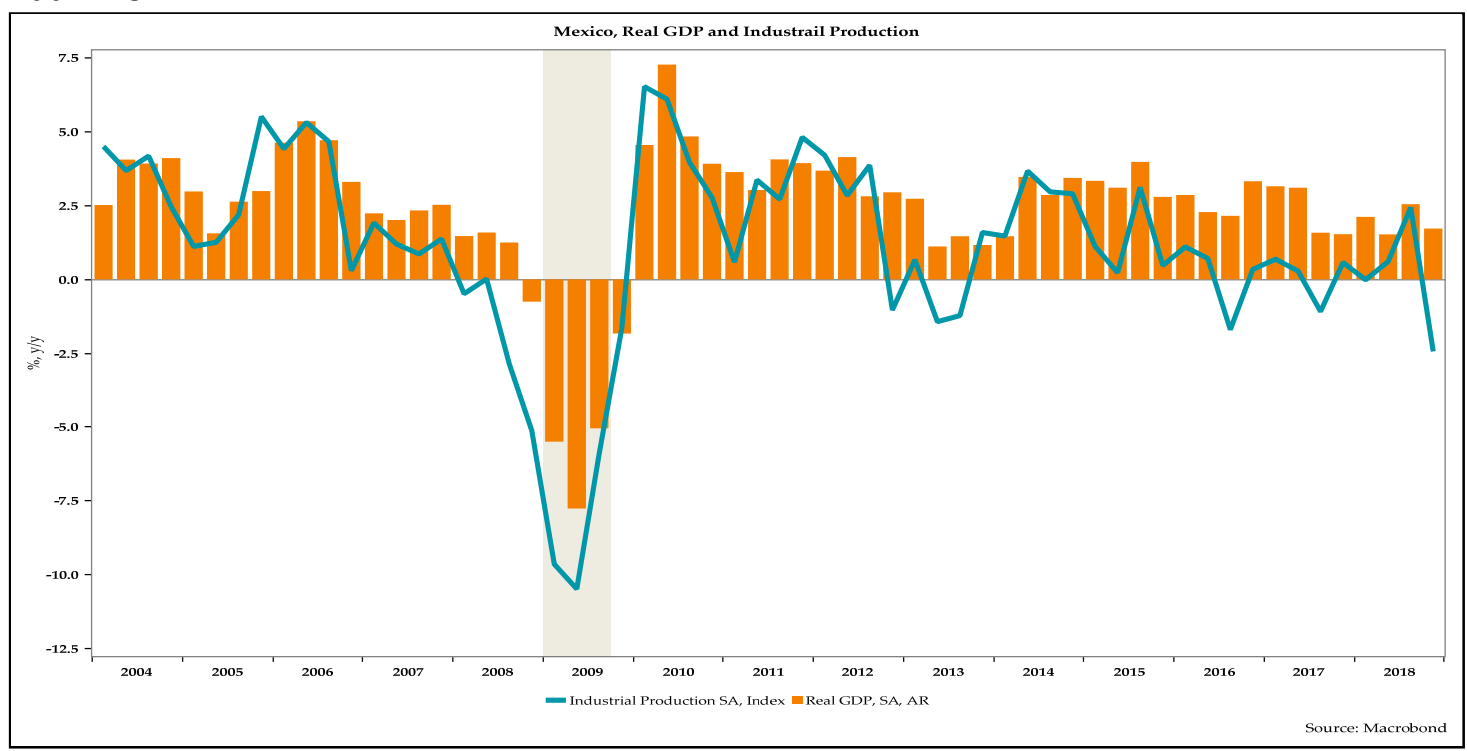


Figure 4. Scatterplot of Growth in Real GDP and Industrial Production in Mexico, 2004-18

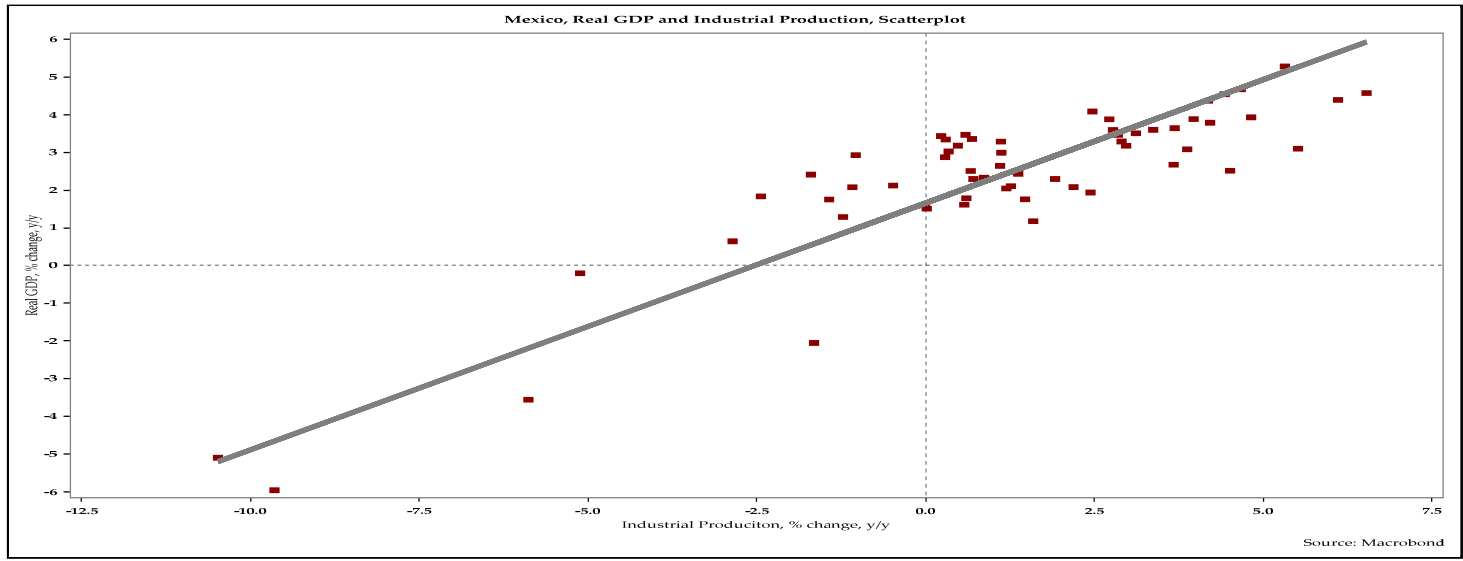

Figure 5 presents the evolution of inflation in Mexico as measured by year-over-year changes in the indices of total consumer price inflation and core consumer price inflation. It is clear that total inflation tends to be more volatile than core inflation. The pace of inflation rose in the years prior to the global financial crisis but fell in the years after the crisis. Inflation rose sharply in early 2017 but partly abated in mid-2018.

Figure 5. The Evolution of Total and Core Consumer Price Index Inflation in Mexico, 2004-18

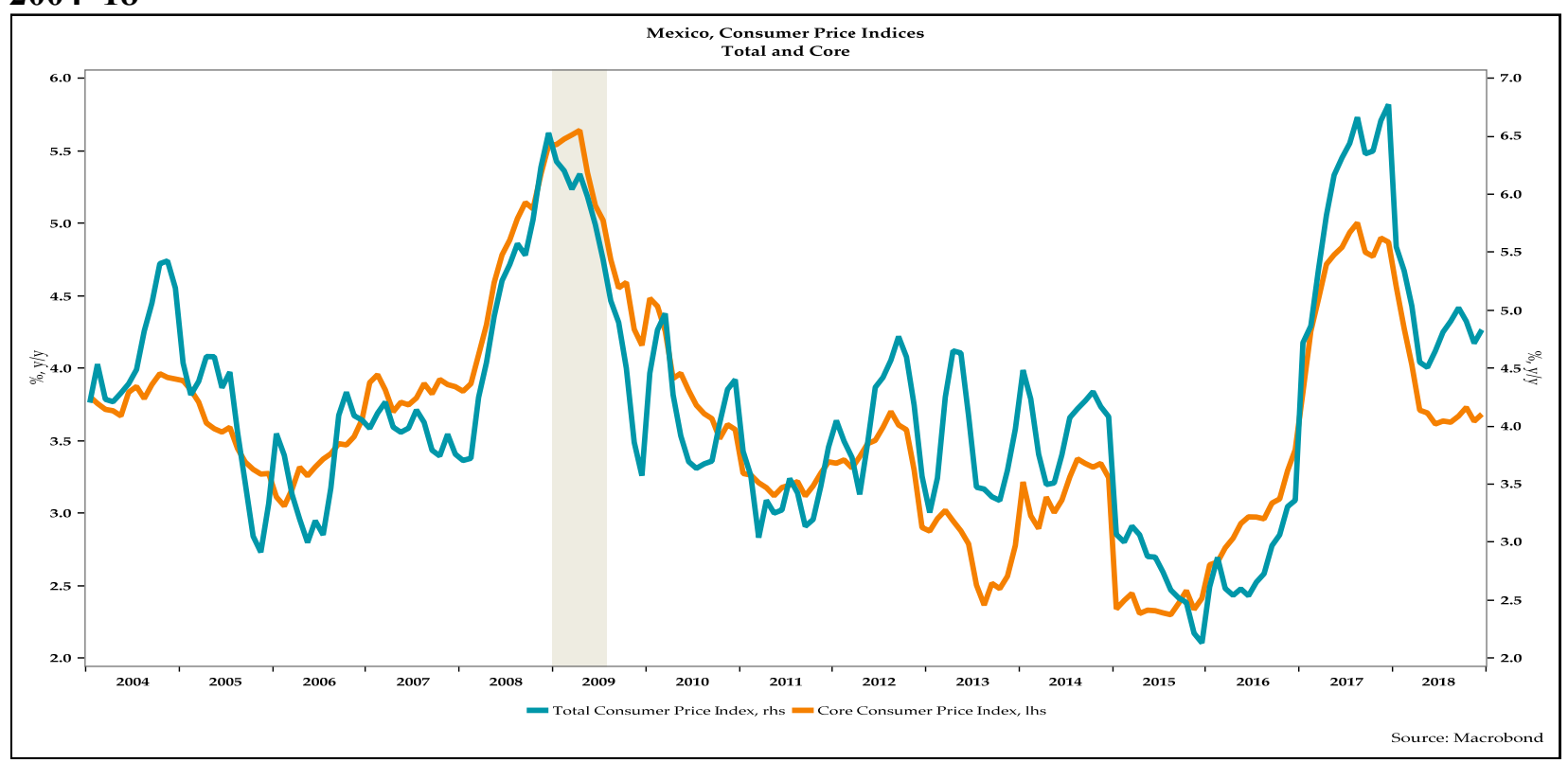


The figures below display several scatterplots. Figure 6 is a scatterplot of the yields of 3-year MGBs and 3-month Cetes. ${ }^{1}$ Figure 7 is a scatterplot of the year-over-year percentage point change in the yields of 3-year MGBs and 3-month Cetes. Figure 8 is a scatterplot of the yields of 5-year MGBs and 3-month Cetes. Figure 9 is a scatterplot of the year-over-year percentage point change in the yields of 5-year MGBs and 3-month Cetes. Figure 10 is a scatterplot of the yields of 10-year MGBs and 3-month Cetes. Figure 11 is a scatterplot of the year-over-year percentage point change in the yields of 10-year MGBs and 3-month Cetes.

Figure 6. Scatterplot of the Yields of 3-year Mexican Government Bonds and 3-month Cetes, 2010-18

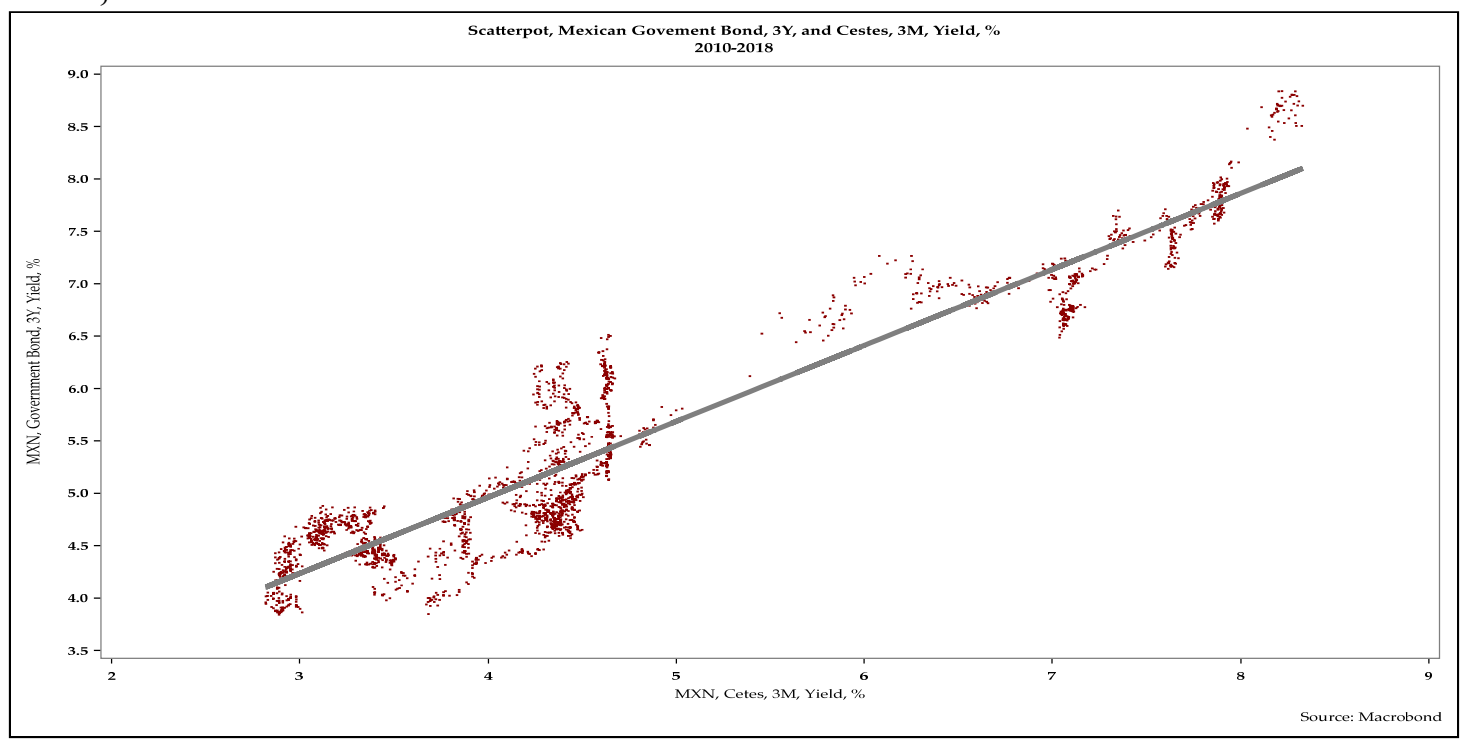

\footnotetext{
${ }^{1}$ The Certificados de la Tesorería de la Federación (Certificates of the Federal Treasury) are debt instruments issued by the Mexican federal government. These are widely known as "Cetes." These securities are zerocoupon bonds that are traded at a discount below their face value. These securities do not pay any interest and are settled at their face value at their maturity date. Typically their maximum term is 12 months.
} 
Figure 7. Scatterplot of the Year-over-Year Percentage Point Changes in the Yields of 3-year Mexican Government Bonds and 3-month Cetes, 2011-18

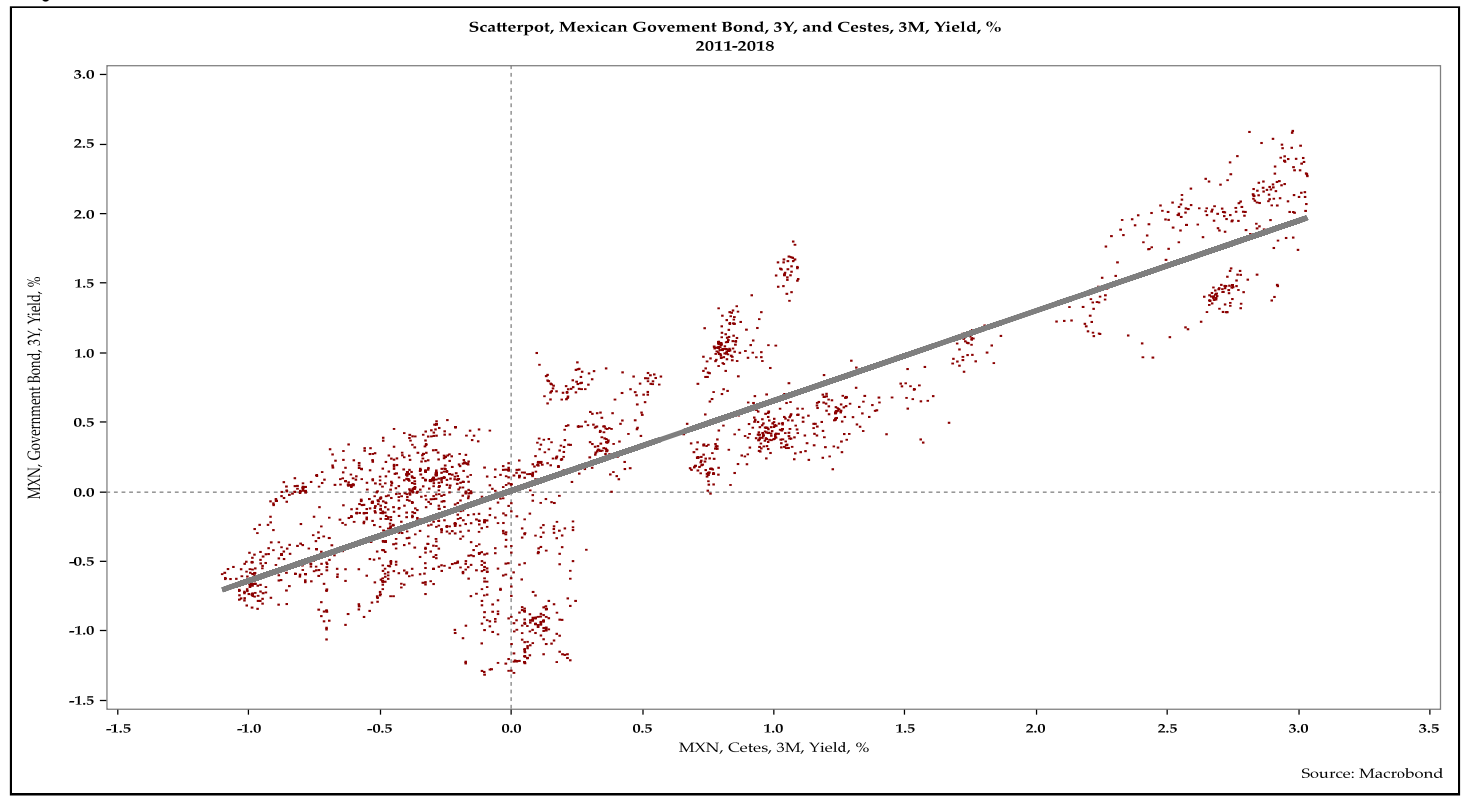

Figure 8. Scatterplot of the Yields of 5-year Mexican Government Bonds and 3-month Cetes, 2004-18

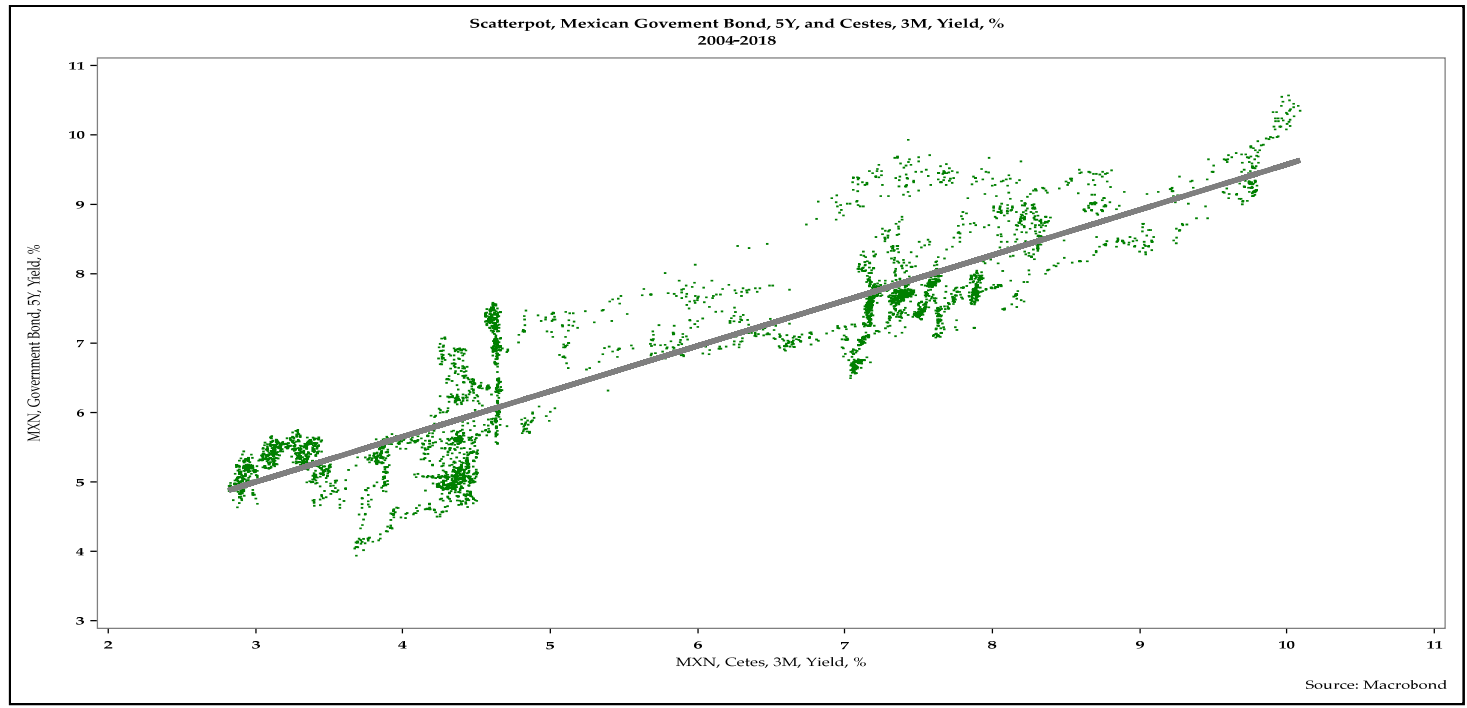


Figure 9. Scatterplot of the Year-over-Year Percentage Point Changes in the Yields of 5-year Mexican Government Bonds and 3-month Cetes, 2005-18

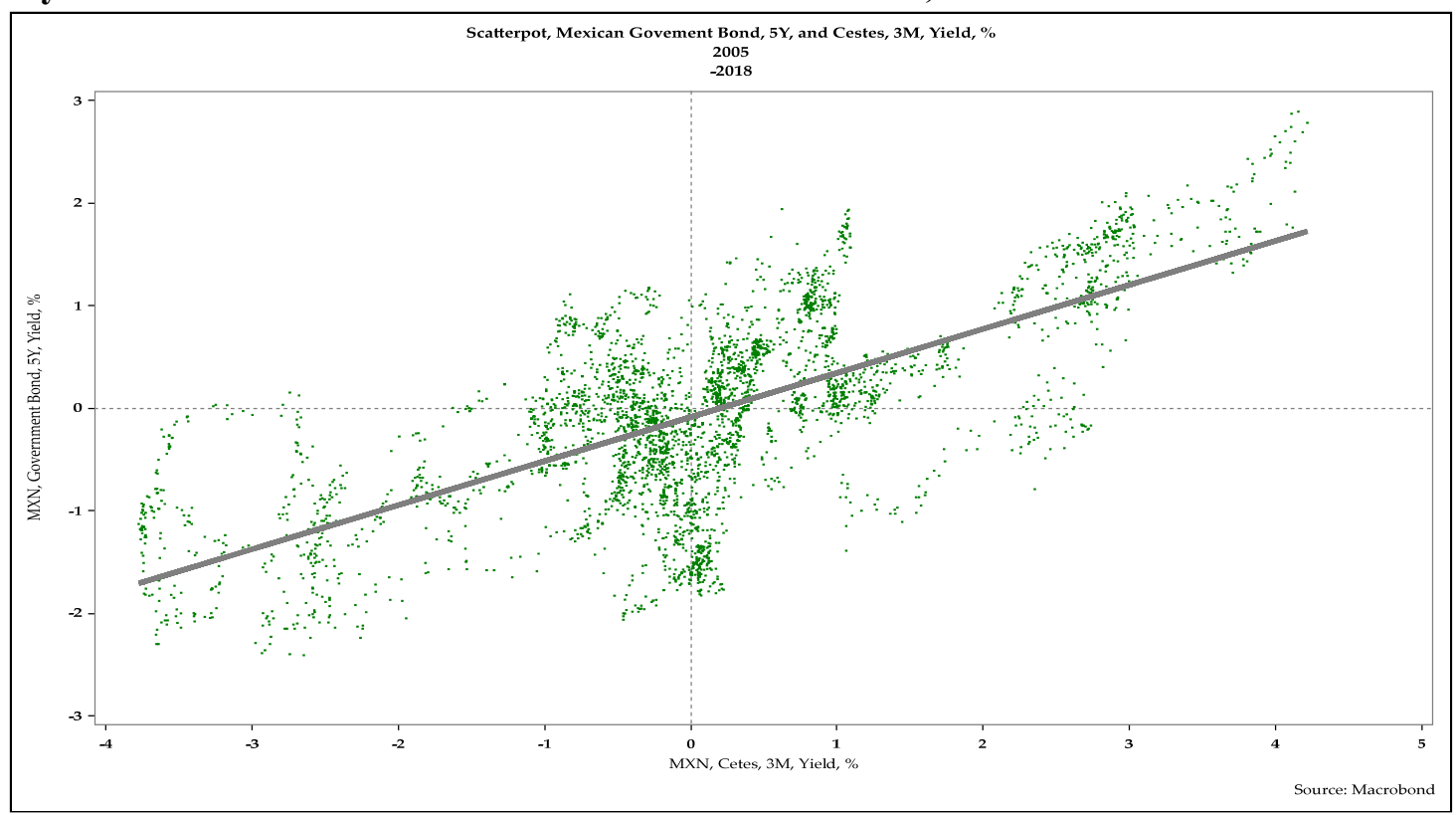

Figure 10. Scatterplot of the Yields of 10-year Mexican Government Bonds and 3month Cetes, 2004-18

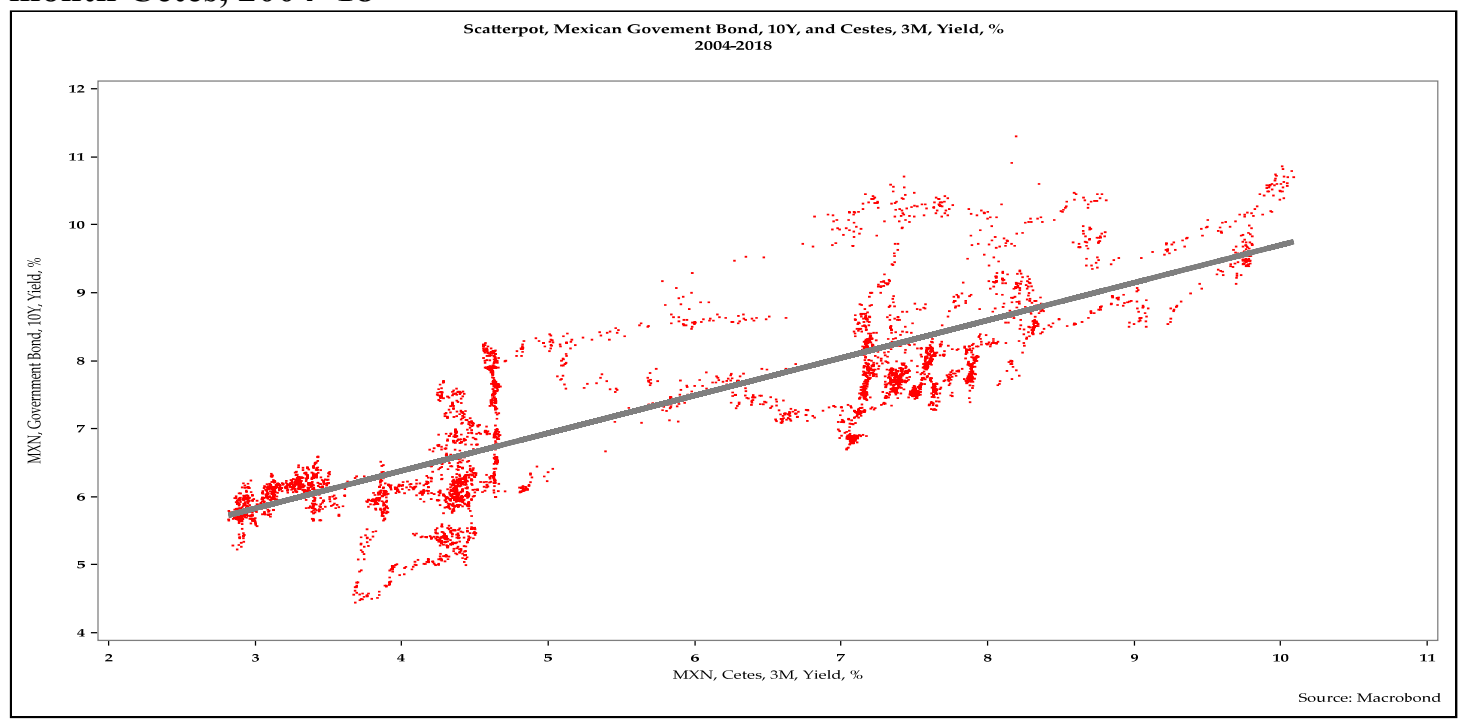


Figure 11. Scatterplot of the Year-over-Year Percentage Point Changes in the Yields of 10-year Mexican Government Bonds and 3-month Cetes, 2005-18

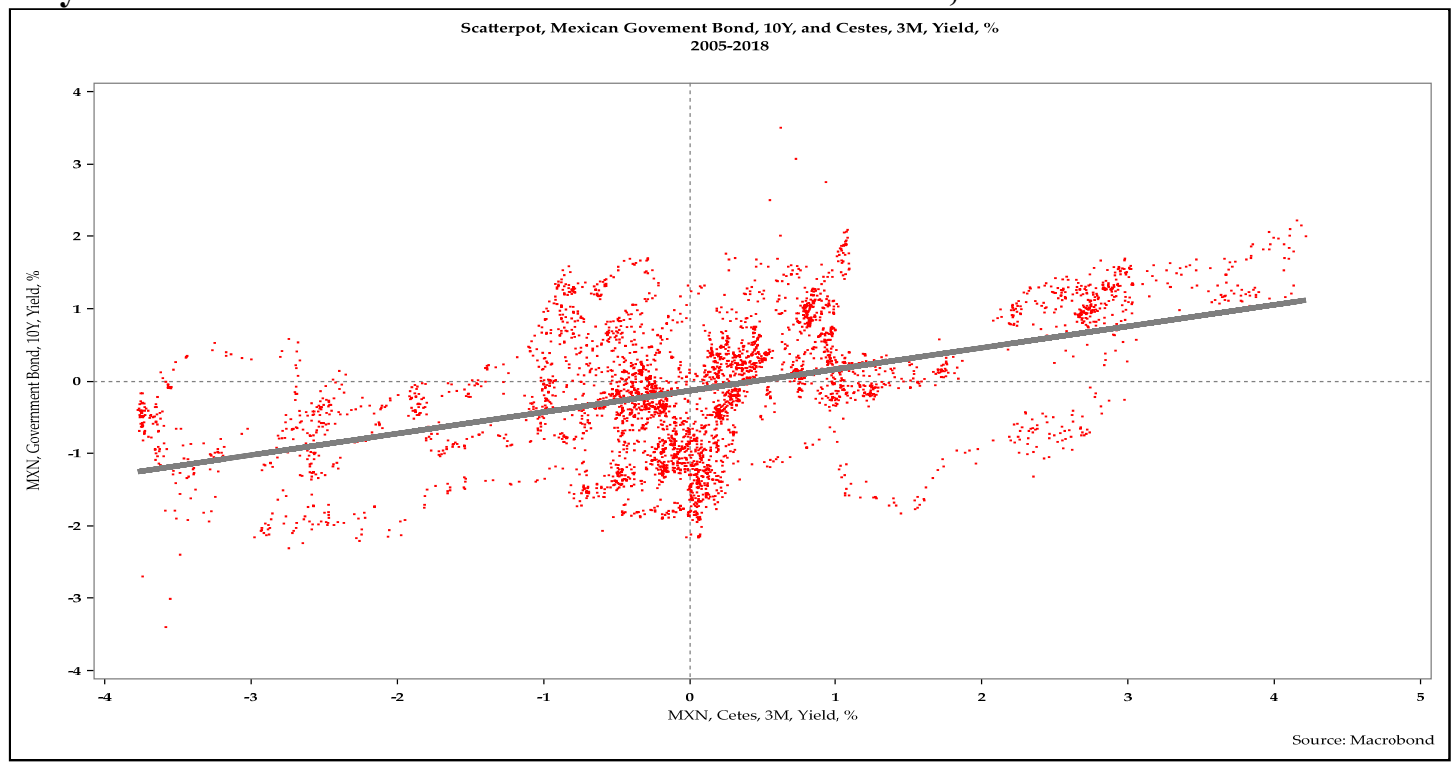

The scatterplots of the yields of MGBs of various tenors, 3-month Cetes, and the year-overyear percentage point changes of these yields reveal some interesting patterns. First, there is a fairly strong positive correlation between the levels of the yields of MGBs of various tenors and 3-month Cetes. Second, there is also a positive correlation between the year-over-year percentage point changes in the yields of MGBs of various tenors and 3-month Cetes but theses correlations are weaker than that of the correlations in the levels of yields. Third, the correlations between the levels of MGBs' and 3-month Cetes' yields and between the yearover-year percentage point changes of MGBs' and 3-month Cetes' yields become less strong with the increase of the MGBs' maturity tenor.

\section{DATA}

Table 1 below summarizes the data and variables used in the paper. The first column gives the variable labels. The second column describes the data and provides the date range. The third column provides the original frequency of the data and states whether it has been converted to monthly frequency. The final column lists the sources of the data. 
The paper uses data on short-term interest rates, as measured by the yields of Mexican Cetes with a maturity between 1-12 months. It also uses data on long-term interest rates, as measured by the yields of MGBs of various maturity tenors across the yield curve from 3 to 10 years. For inflation, it relies on two measures as reflected in the total consumer price index and the core consumer price index, both measured a year-over-year percentage change basis. The indicator of economic activity is based on the index of industrial production and real GDP, measured in year-over-year percentage change.

The time period covered in this paper is from January 2004 to December 2018, covering 204 months. Monthly data are used in the empirical analysis. The daily data from the bond market are converted to monthly frequency. 
Table 1. Summary of the Data and the Variables

\begin{tabular}{|c|c|c|c|}
\hline $\begin{array}{l}\text { Variable } \\
\text { labels }\end{array}$ & Data description, date range & Frequency & Sources \\
\hline \multicolumn{4}{|c|}{ Short-term interest rates } \\
\hline CETES1M & $\begin{array}{l}\text { Mexican Cetes, 1-month, yield, \%, } \\
\text { January } 2014 \text { - December } 2018\end{array}$ & $\begin{array}{l}\text { Daily; } \\
\text { converted to } \\
\text { monthly }\end{array}$ & $\begin{array}{l}\text { Banco de Mexico; } \\
\text { Macrobond }\end{array}$ \\
\hline CETES3M & $\begin{array}{l}\text { Mexican Cetes, 3-month, yield, \%, } \\
\text { January } 2014 \text { - December } 2018\end{array}$ & $\begin{array}{l}\text { Daily; } \\
\text { converted to } \\
\text { monthly }\end{array}$ & $\begin{array}{l}\text { Banco de Mexico; } \\
\text { Macrobond }\end{array}$ \\
\hline CETES6M & $\begin{array}{l}\text { Mexican Cetes, 6-month, yield, \%, } \\
\text { January } 2014 \text { - December } 2018\end{array}$ & $\begin{array}{l}\text { Daily; } \\
\text { converted to } \\
\text { monthly }\end{array}$ & $\begin{array}{l}\text { Banco de Mexico; } \\
\text { Macrobond }\end{array}$ \\
\hline CETES12M & $\begin{array}{l}\text { Mexican Cetes, 12-month, yield, \%, } \\
\text { January } 2014 \text { - December } 2018\end{array}$ & $\begin{array}{l}\text { Daily; } \\
\text { converted to } \\
\text { monthly }\end{array}$ & $\begin{array}{l}\text { Banco de Mexico; } \\
\text { Macrobond }\end{array}$ \\
\hline \multicolumn{4}{|c|}{ Government bond yields } \\
\hline MGB3Y & $\begin{array}{l}\text { Mexican government bonds, 3-year, } \\
\text { yield, \%, } \\
\text { January } 2014 \text { - December } 2018\end{array}$ & $\begin{array}{l}\text { Daily; } \\
\text { converted to } \\
\text { monthly }\end{array}$ & Macrobond \\
\hline MGB5Y & $\begin{array}{l}\text { Mexican government bonds, 5-year, } \\
\text { yield, \%, } \\
\text { January } 2014 \text { - December } 2018\end{array}$ & $\begin{array}{l}\text { Daily; } \\
\text { converted to } \\
\text { monthly }\end{array}$ & Macrobond \\
\hline MGB10Y & $\begin{array}{l}\text { Mexican government bonds, 10-year, } \\
\text { yield, \%, } \\
\text { January } 2014 \text { - December } 2018\end{array}$ & $\begin{array}{l}\text { Daily; } \\
\text { converted to } \\
\text { monthly }\end{array}$ & Macrobond \\
\hline \multicolumn{4}{|c|}{ Rate of core inflation } \\
\hline TCPI & $\begin{array}{l}\text { Consumer price index, total, index, \% } \\
\text { change, y/y, } \\
\text { January } 2014 \text { - December } 2018\end{array}$ & Monthly & $\begin{array}{l}\text { National Institute of } \\
\text { Geography and } \\
\text { Statistics; } \\
\text { Macrobond }\end{array}$ \\
\hline CCPI & $\begin{array}{l}\text { Consumer price index, core, index, \% } \\
\text { change, y/y, } \\
\text { January } 2014 \text { - December } 2018\end{array}$ & Monthly & $\begin{array}{l}\text { National Institute of } \\
\text { Geography and } \\
\text { Statistics; } \\
\text { Macrobond }\end{array}$ \\
\hline \multicolumn{4}{|c|}{ Pace of economic activity } \\
\hline IP & $\begin{array}{l}\text { Industrial production, SA, index, \% } \\
\text { change, y/y, } \\
\text { January } 2014 \text { - December } 2018\end{array}$ & Monthly & $\begin{array}{l}\text { National Institute of } \\
\text { Geography and } \\
\text { Statistics; } \\
\text { Macrobond }\end{array}$ \\
\hline
\end{tabular}




\section{EMPIRICAL MODELS AND INTERPRETATION OF THE FINDINGS}

\section{Methodology}

This paper uses the autoregressive distributed lag (ARDL) approach to model the dynamics of MGB yields. It will be explained below why this modeling choice is appropriate given the unit root properties of the time series data. To run an ARDL model several basic steps need to be completed.

First, unit root tests are performed to test for stationarity. Unit roots tests are conducted for each series. Tables $2 \mathrm{a}$ and $2 \mathrm{~b}$ show that all the independent variables and dependent variables, except IP, are nonstationary at levels but stationary at first difference. These variables are a mix of both $\mathrm{I}(0)$ and $\mathrm{I}(1)$. None of the variables are $\mathrm{I}(2)$. This suggests that it is appropriate to use an ARDL approach to model the dynamic relations between these variables.

Second, cointegration tests are applied to determine if there is a long-run relationship between the variables. Bound tests, based on the Pesaran, Shin, and Smith (2001), are deployed to check the long-run relationships among the variables. Table 3 shows that the null hypothesis of no long-run relationship between the variables can be rejected for most models.

Third, the long-run equilibrium relationship and multivariate short-run dynamic error correction models are estimated. These models testify there is a relationship between MGB yields and the short-term interest rate in both the long run and the short run.

\section{Unit Root Tests}

The stationarity properties in the time series are established by executing the following unit root tests: (1) the Augmented Dickey-Fuller (ADF) (Dickey and Fuller 1981) and (2) Phillips-Perron (PP) (Phillips and Perron 1988) tests. The tests are executed on levels and the first difference forms for each variable. Table $2 a$ shows the unit root test results. ${ }^{2}$ Table $2 b$ displays the unit root tests for the first differences for the same variables. It is evident from tables $2 \mathrm{a}$ and $2 \mathrm{~b}$ that most of the variables are nonstationary in their levels but are stationary

\footnotetext{
${ }^{2}$ Phillips and Perron unit root tests are also conducted. The results yield identical conclusions. The results are provided in appendix A.
} 
in their first differences. CETES3M, MGBs, TCPI, and CCPI are I(1) at the 1 percent level of significance. However, IP is stationary both in level and first difference forms at a 5 percent level of significance. Thus, the unit root tests show that there is a mixture of $\mathrm{I}(1)$ and $\mathrm{I}(0)$ processes among the variables that will be used in the model(s). Therefore, the bounds testing approach is more appropriate than the Johansen cointegrating approach for analyzing longrun behavior.

Table 2a. Augment Dickey-Fuller Unit Root Tests under Different Specifications in Level

\begin{tabular}{|c|c|c|}
\hline Variable & Type & Test Stat \\
\hline \multirow{3}{*}{ CETES1M } & Drift & -1.560 \\
\hline & Trent & -1.181 \\
\hline & No constant & -0.305 \\
\hline \multirow{3}{*}{ CETES3M } & Drift & -1.628 \\
\hline & Trent & -1.250 \\
\hline & No constant & -0.374 \\
\hline \multirow{3}{*}{ CETES6M } & Drift & -1.403 \\
\hline & Trent & -0.888 \\
\hline & No constant & -0.233 \\
\hline \multirow{3}{*}{ CETES12M } & Drift & -1.267 \\
\hline & Trent & -0.777 \\
\hline & No constant & -0.116 \\
\hline \multirow{3}{*}{ MGB3Y } & Drift & 0.101 \\
\hline & Trent & -1.203 \\
\hline & No constant & 0.749 \\
\hline \multirow{3}{*}{ MGB5Y } & Drift & $-1.460^{*}$ \\
\hline & Trent & -1.180 \\
\hline & No constant & -0.064 \\
\hline \multirow{3}{*}{ MGB10Y } & Drift & -1.642 \\
\hline & Trent & -1.409 \\
\hline & No constant & -0.209 \\
\hline \multirow{3}{*}{ TCPI } & Drift & -1.416 \\
\hline & Trent & -1.226 \\
\hline & No constant & -0.051 \\
\hline \multirow{3}{*}{ CCPI } & Drift & -2.088 \\
\hline & Trent & -1.996 \\
\hline & No constant & 0.018 \\
\hline \multirow{3}{*}{ IP } & Drift & $-2.100 * *$ \\
\hline & Trent & $-2.138 * *$ \\
\hline & No constant & $-2.082 * *$ \\
\hline
\end{tabular}

Note: $*$ and $* *$ indicate statistical significance at the 10 percent and 5 percent levels, respectively. 
Table 2b. Augmented Dickey-Fuller Unit Root Test under Different Specifications in Their First Difference

\begin{tabular}{|c|c|c|c|}
\hline Variable & Types & $\begin{array}{l}\text { Test } \\
\text { statistic }\end{array}$ & $\begin{array}{l}\text { Integration } \\
\text { order }\end{array}$ \\
\hline \multirow{3}{*}{$\Delta$ CETES1M } & Drift & $-3.929 * * *$ & $\mathrm{I}(1)$ \\
\hline & Trent & $-4.025 * * *$ & $\mathrm{I}(1)$ \\
\hline & No constant & $-3.932 * * *$ & $\mathrm{I}(1)$ \\
\hline \multirow{3}{*}{$\triangle$ CETES3M } & Drift & $-4.039 * * *$ & $\mathrm{I}(1)$ \\
\hline & Trent & $-4.197 * * *$ & $\mathrm{I}(1)$ \\
\hline & No constant & $-4.059 * * *$ & $\mathrm{I}(1)$ \\
\hline \multirow{3}{*}{$\triangle$ CETES6M } & Drift & $-4.243 * * *$ & $\mathrm{I}(1)$ \\
\hline & Trent & $-4.442 * * *$ & $\mathrm{I}(1)$ \\
\hline & No constant & $-4.262 * * *$ & $\mathrm{I}(1)$ \\
\hline \multirow{3}{*}{$\triangle$ CETES12M } & Drift & $-5.055 * * *$ & $\mathrm{I}(1)$ \\
\hline & Trent & $-5.267 * * *$ & $\mathrm{I}(1)$ \\
\hline & No constant & $-5.078 * * *$ & $\mathrm{I}(1)$ \\
\hline \multirow{3}{*}{$\Delta$ MGB3Y } & Drift & $-11.540 * * *$ & $\mathrm{I}(1)$ \\
\hline & Trent & $-12.330 * * *$ & $\mathrm{I}(1)$ \\
\hline & No constant & $-11.522 * * *$ & $\mathrm{I}(1)$ \\
\hline \multirow{3}{*}{$\Delta$ MGB5Y } & Drift & $-13.980 * * *$ & $\mathrm{I}(1)$ \\
\hline & Trent & $-14.020 * * *$ & $\mathrm{I}(1)$ \\
\hline & No constant & $-14.020 * * *$ & $\mathrm{I}(1)$ \\
\hline \multirow{3}{*}{$\triangle \mathrm{MGB10Y}$} & Drift & $-13.040 * * *$ & $\mathrm{I}(1)$ \\
\hline & Trent & $-13.070 * * *$ & $\mathrm{I}(1)$ \\
\hline & No constant & $-13.080 * * *$ & $\mathrm{I}(1)$ \\
\hline \multirow{3}{*}{$\triangle \mathrm{TCPI}$} & Drift & $-4.744 * * *$ & $\mathrm{I}(1)$ \\
\hline & Trent & $-4.772 * * *$ & $\mathrm{I}(1)$ \\
\hline & No constant & $-4.754 * * *$ & $\mathrm{I}(1)$ \\
\hline \multirow{3}{*}{$\Delta \mathrm{CCPI}$} & Drift & $-4.450 * * *$ & $\mathrm{I}(1)$ \\
\hline & Trent & $-4.528 * * *$ & $\mathrm{I}(1)$ \\
\hline & No constant & $-4.447 * * *$ & $\mathrm{I}(1)$ \\
\hline \multirow{3}{*}{$\Delta \mathbf{I P}$} & Drift & $-6.419 * * *$ & $\mathrm{I}(0) / \mathrm{I}(1)$ \\
\hline & Trent & $-6.386^{* * *}$ & $\mathrm{I}(0) / \mathrm{I}(1)$ \\
\hline & No constant & $-6.418 * * *$ & $\mathrm{I}(0) / \mathrm{I}(1)$ \\
\hline
\end{tabular}

Note: $* * *$ indicates statistical significance is at the 1 percent level. 


\section{Bounds Tests}

The general form of the ARDL models used in this paper are as follows:

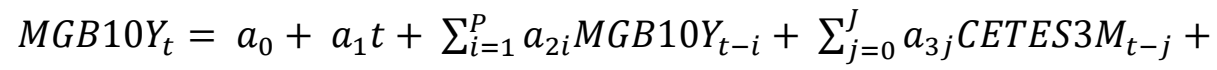

$\sum_{k=0}^{K} a_{4 k} C C P I_{t-k}+\sum_{i=0}^{L} a_{5 k} I P_{t-l}+\varepsilon_{t}$

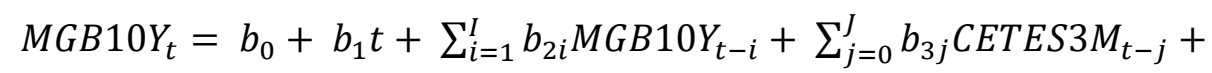

$\sum_{k=0}^{K} b_{4 k} T C P I_{t-k}+\sum_{l=0}^{L} b_{5 l} I P_{t-l}+\varepsilon_{t}$

where $P \geq 1 ; J, K$, and $L \geq 0$. Here equation [6a] has CCPI as a regressor, while equation $[6 \mathrm{~b}]$ has TCPI as a regressor.

In this paper the conditional error correction forms of a general ARDL model are as follows:

$$
\begin{aligned}
& \Delta M G B 10 Y_{t}=c_{0}+c_{1} t+\sum_{i=1}^{P} c_{2 i} \Delta M G B 10 Y_{t-i}+\sum_{j=0}^{J} c_{3 j} \Delta C E T E S 3 M_{t-j}+ \\
& \sum_{l=0}^{K} c_{4 k} \Delta C C P I_{t-k}+\sum_{l=0}^{L} c_{5 l} \Delta I P_{t-l}+\varepsilon_{t} \\
& \Delta M G B 10 Y_{t}=d_{0}+d_{1} t+\sum_{i=1}^{P} d_{2 i} \Delta M G B 10 Y_{t-i}+\sum_{j=0}^{J} d_{3 j} \Delta C E T E S 3 M_{t-j}+ \\
& \sum_{k=0}^{K} d_{4 k} \Delta T C P I_{t-k}+\sum_{l=0}^{L} d_{5 l} \Delta I P_{t-l}+\varepsilon_{t}
\end{aligned}
$$

where equation [7] has CCPI as a regressor, while equation [8] has TCPI as a regressor. Other independent variables are the same. The order of the lags $(\mathrm{P}, \mathrm{J}, \mathrm{K}, \mathrm{L})$ in the bounds testing procedure are selected using the Akaike information criterion (AIC). Since the data series are monthly, the maximum number of lags is set equal to 24 months. The null $\left(\mathrm{H}_{0}\right)$ hypothesis is no cointegration among variables, while the alternative $\left(\mathrm{H}_{\mathrm{a}}\right)$ hypothesis is that there is cointegration among the variables. 
Based on the assumptions made by Pesaran, Shin, and Smith (2001), five models are specified for the cointegrating bounds test (see table 3):

- Model 1: contains no intercepts and no trends

- Model 2: contains restricted intercepts and no trends

- Model 3: contains unrestricted intercepts and no trends

- Model 4: contains unrestricted intercepts and restricted trends

- Model 5: contains unrestricted intercepts and unrestricted trends

According to Pesaran, Shin, and Smith (2001), the null hypothesis cannot be rejected if the calculated F-statistic is less than the critical value for lower-bound regressors and the null is rejected if the calculated F-statistic is higher than the critical value for upper-bound regressors. Similarly, the null hypothesis cannot be rejected if the calculated t-statistic is higher than the critical value for lower-bound regressors, but it is rejected if the calculated tstatistic is lower than the critical value for upper-bound regressors. Table 3 for model 1 shows the calculated and critical values of the F-statistic and t-statistic based on the bounds test. $^{3}$

From table 3, for model 1, F-values are lower than critical values for each level of significance test, while calculated t-values are higher than the critical t-values for each level of significance tests. The findings concerning model 1 are inconclusive about any long-run relation because one cannot reject the null hypothesis of no level cointegration. However, for models 2-5, the F-values are in between the upper and lower bound of critical F-values at 1 percent significance, while the calculated F-values are higher than the upper bound of Fvalues at the 5 percent and 10 percent significance levels. Hence, the null hypothesis of no level relationship in the long run can be rejected. Besides the F-test, the t-value from the bounds test also confirms the validity of the long-run level relationship among the variables.

\footnotetext{
${ }^{3}$ Pesaran, Shin, and Smith (2001) shows that a long-run association is present among the variables if the calculated F-values are greater than the value of the upper bound; no long-run association exists if the calculated F-statistic's value is less than the lower-bounds value and the decision is inconclusive if the calculated Fstatistic's value falls between the lower- and upper-bounds value. If the calculated F-value is higher than the upper-bound value, there is cointegration. If the calculated F-statistic is lower than the lower-bound critical value, then there is no cointegration. Hence, there is no long-run relationship.

From table 3 it is evident that, except model 1, all the models are showing that the calculated F-statistics is higher than the critical value for upper bounds at a 5 percent significance level. Therefore, the evidence suggest that theses variables possess a long-run relationship.
} 
Except for model 1, all other models have a calculated t-value higher than critical t-values at the 5 percent and 10 percent significance levels. Therefore, there is evidence of a long-run cointegrating relationship among the variables in most models under consideration.

With the confirmation of the long-run equilibrium relationship among MGB10Y yields, the short-term interest rate, core inflation, and the growth of industrial production, a dynamic multivariate vector error correction (VEC) model is estimated. 
Table 3. Pesaran, Shin, and Smith (2001) Bounds Test for MGB10Y

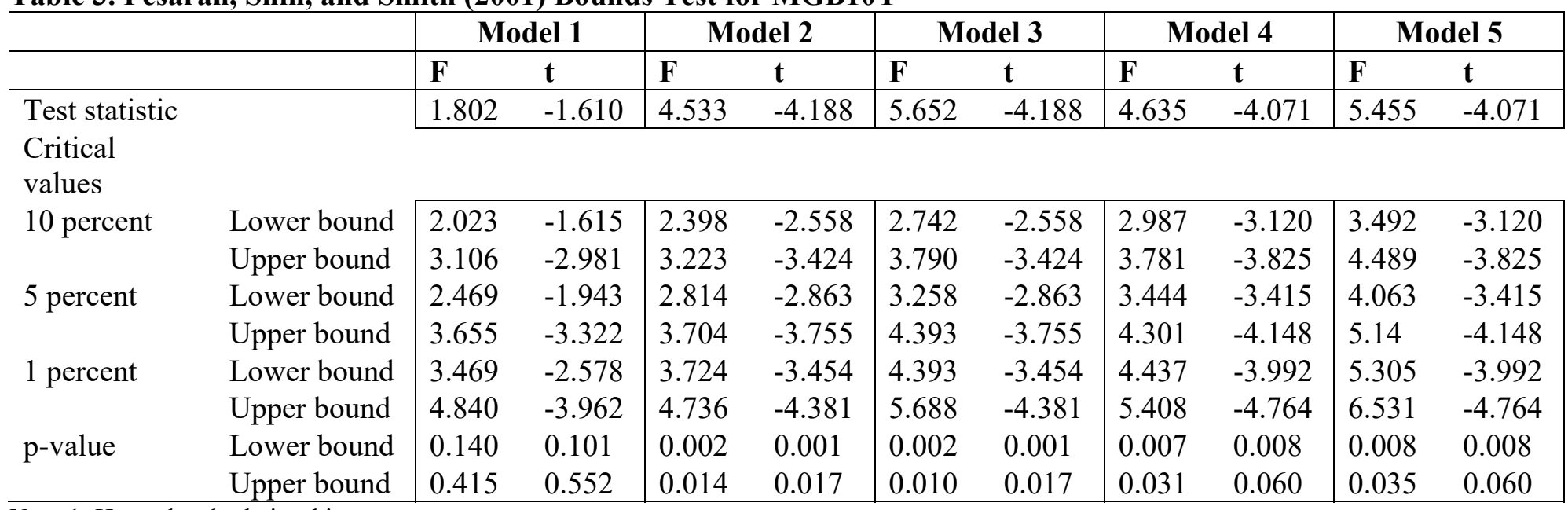

Note 1: $\mathrm{H}_{0}$ : no level relationship.

Note 2: Dependent variable is MGB10Y and independent variables are CETES3M, CCPI, and IP.

Note 3: Model 1: no intercept and no trend; Model 2: restricted intercept and no trend; Model 3: unrestricted and no trend; Model 4: unrestricted intercept and trend; and Model 5: unrestricted intercept and trend. 
A dynamic VEC model is used for estimating short-run coefficients by restricting long-run relationships through the cointegrating equations. The error correction term gives the speed of adjustment. The error correction term shows how long-run equilibrium is achieved over time from a short-run deviation. ${ }^{4}$

Tables $4 \mathrm{a}$ and $4 \mathrm{~b}$ present the estimation of VEC models using the cointegrating bounds test. Table $4 \mathrm{a}$ presents the long-run coefficients of the estimated models, while table $4 \mathrm{~b}$ presents the short-run coefficients and the adjustment coefficients from short-run to long-run equilibrium for the same models.

Table 4a. Long-run Coefficients of Models Using the ARDL Technique for MGB10Y

\begin{tabular}{llllll}
\hline \multirow{2}{*}{ CETES3M } & \multicolumn{1}{c}{ Model 1 } & \multicolumn{1}{c}{ Model 2 } & \multicolumn{1}{c}{ Model 3 } & \multicolumn{1}{c}{ Model 4 } & \multicolumn{1}{c}{ Model 5 } \\
\cline { 2 - 6 } & $0.572^{* * *}$ & $0.551^{* * *}$ & $0.551^{* * *}$ & $0.429^{* * *}$ & $0.429^{* * *}$ \\
CCPI & $(0.0907)$ & $(0.1530)$ & $(0.1530)$ & $(0.1200)$ & $(0.1200)$ \\
& -0.172 & -0.159 & -0.159 & -0.0378 & -0.0378 \\
IP & $(0.1940)$ & $(0.3300)$ & $(0.3300)$ & $(0.2200)$ & $(0.2200)$ \\
& $-0.156^{*}$ & -0.198 & -0.198 & $-0.179^{*}$ & $-0.179^{*}$ \\
Trend & $(0.0681)$ & $(0.1210)$ & $(0.1210)$ & $(0.0778)$ & $(0.0778)$ \\
& & & & $-0.010^{*}$ & \\
Constant & & & & $(0.0042)$ & \\
& & $4.921^{* * *}$ & & & \\
\hline$N$ & & $(1.3150)$ & & 177 & 177 \\
Adj. $R^{2}$ & 171 & 177 & 177 & 0.305 & 0.305 \\
\hline
\end{tabular}

Note 1: Standard errors in parentheses, ${ }^{*} p<0.05,{ }^{* *} p<0.01,{ }^{* * *} p<0.001$.

Note 2: Dependent variable is MGB10Y and independent variables are CETES3M, CCPI, and IP. Note 3: Model 1: no intercept and no trend; Model 2: restricted intercept and no trend; Model 3: unrestricted and no trend; Model 4: unrestricted intercept and trend; and Model 5: unrestricted intercept and trend.

\footnotetext{
${ }^{4}$ The short-run relation can be found from the ARDL model using the following equation:

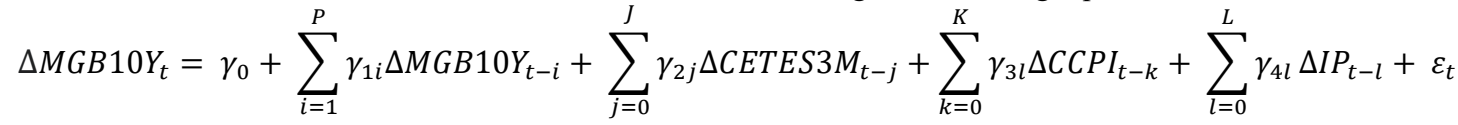


Table 4b. Short-run and Error Correction Coefficients Using the ARDL Technique Using Equation [7]

\begin{tabular}{|c|c|c|c|c|c|}
\hline & Model 1 & Model 2 & Model 3 & Model 4 & Model 5 \\
\hline $\begin{array}{l}\text { Speed of adjustment } \\
\text { MGB10Y }(-1)\end{array}$ & $\begin{array}{l}-0.139^{* * *} \\
(0.033)\end{array}$ & $\begin{array}{l}-0.084^{* *} \\
(0.030)\end{array}$ & $\begin{array}{l}-0.084^{* *} \\
(0.030)\end{array}$ & $\begin{array}{l}-0.128^{* * *} \\
(0.037)\end{array}$ & $\begin{array}{l}-0.128^{* * *} \\
(0.037)\end{array}$ \\
\hline $\begin{array}{l}\text { Short-run dynamics } \\
\Delta \text { CETES3M }\end{array}$ & $\begin{array}{l}0.730^{* * *} \\
(0.105)\end{array}$ & $\begin{array}{l}0.781^{* * *} \\
(0.010)\end{array}$ & $\begin{array}{l}0.781^{* * *} \\
(0.010)\end{array}$ & $\begin{array}{l}0.823^{* * *} \\
(0.101)\end{array}$ & $\begin{array}{l}0.823^{* * *} \\
(0.101)\end{array}$ \\
\hline$\triangle$ CETES3M (-1) & $-0.333^{* *}$ & $-0.359^{* * *}$ & $-0.359^{* * *}$ & $-0.291^{* *}$ & $-0.291^{* *}$ \\
\hline$\Delta$ CETES3M (-2) & $\begin{array}{l}(0.101) \\
-0.149\end{array}$ & $(0.010)$ & $(0.010)$ & $(0.105)$ & $(0.105)$ \\
\hline$\Delta \mathrm{IP}$ & $\begin{array}{l}(0.105) \\
0.028 \\
(0.017)\end{array}$ & & & $\begin{array}{l}0.027 \\
(0.017)\end{array}$ & $\begin{array}{l}0.027 \\
(0.017)\end{array}$ \\
\hline Trend & & & & & $\begin{array}{l}-0.001 \\
(0.001)\end{array}$ \\
\hline Constant & $\begin{array}{l}0.658^{* * *} \\
(0.178)\end{array}$ & & $\begin{array}{l}0.412^{*} \\
(0.163)\end{array}$ & $\begin{array}{l}1.368^{*} \\
(0.553)\end{array}$ & $\begin{array}{l}1.368^{*} \\
(0.553)\end{array}$ \\
\hline$N$ & 171 & 177 & 177 & 177 & 177 \\
\hline $\begin{array}{l}\text { Adj. } R^{2} \\
\text { ARDL Lag structure }\end{array}$ & 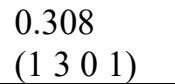 & 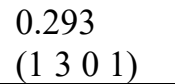 & 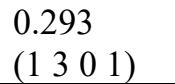 & 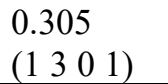 & 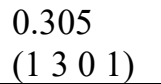 \\
\hline
\end{tabular}

Note 1: Standard errors in parentheses, ${ }^{*} p<0.05,{ }^{* *} p<0.01,{ }^{* * *} p<0.001$.

Note 2: ADJ presents the adjustment coefficients and short-run presents the short-run coefficients.

Note 3: Dependent variable is MGB10Y and independent variables are CETES3M, CCPI, and IP.

From table 4a, for all five models, the main variable of concern, namely, the short-term interest rate (CETES3M), is positively related to MGB10Y. The estimated elasticity ranges from 0.42 to 0.57 . This indicates that a 1 percentage point increase in the short-term interest rate is associated with a long-run increase of around 42 to 57 basis points in MGB10Y's yield. The core consumer price inflation and the growth of industrial production are negatively correlated with MGB10Y yields. The estimated elasticities range from 0.037 to 0.172 and 0.15 to 0.19 , respectively, for core inflation and the growth of industrial production.

Most of the empirical results obtained are in concordance with the Keynesian hypothesis that the short-term interest rate is the main driver of the long-term interest rate. The results show that a higher (lower) short-term interest rate leads to a higher (lower) long-term yield on MGBs. The findings concerning the effect of the rate of inflation and the growth of industrial production are somewhat counterintuitive, but there are plausible economic and econometric explanations. 
The results show that an increase (decrease) in the rate of core inflation is associated with a lower (higher) MGB yield. The results also show that as the growth of industrial production increases (decreases), long-term MGB yields fall (rise). If the BdM's policy actions are motivated by a Taylor-type rule, then it responds by raising (lowering) the policy rate due to incoming information about either observed inflationary pressures and/or expectations of higher inflation. The short-term interest rate changes with BdM's policy actions. Thus, the effect of core inflation on a government bond yield is negative rather than positive, after controlling for the short-term interest rate.

Likewise, if the BdM raises (lowers) the policy rate because of the strength (weakness) of industrial production, the effect of industrial production's growth on government bond yields could be negative rather than positive. The collinearity between the short-term interest rate and other relevant variables, such as inflation and the growth of industrial production, may also explain the apparent anomalies.

The coefficients of the error correction term in the long-term interest rate equation are significant at the 1 percent level with the expected negative sign (table $4 \mathrm{~b}$ ). This confirms the results of the bounds test for cointegration. The coefficients of the error correction term range from 0.083 to 0.139 . This implies that about 11 percent ( $8-14$ percent) of the disequilibria caused by shocks on the short-term interest rate, inflation, and the growth of industrial production are corrected within a span of one month. The results of the short-run error correction model are presented in the panel of short-run coefficients in table 4b. Most of the short-run coefficients are significant, except for a few lagged differences in the short-term interest rates. The signs of the short-run dynamic impacts are consistent with the long-run results.

Diagnostic tests are conducted to assess misspecifications, autocorrelations, and heteroscedasticity. The results are shown in table 5 below. 
Table 5. Parameter Stability Test for MGB10Y Using Equation [7]

\begin{tabular}{|c|c|c|c|c|c|}
\hline & Model 1 & Model 2 & Model 3 & Model 4 & Model 5 \\
\hline \multicolumn{6}{|c|}{ a. Breusch-Pagan test for heteroscedasticity } \\
\hline chi2 & 0.090 & 0.170 & 0.170 & 0.130 & 0.130 \\
\hline p-value & 0.761 & 0.684 & 0.684 & 0.716 & 0.716 \\
\hline \multicolumn{6}{|c|}{ b. Breusch-Godfrey test for autocorrelation } \\
\hline chi2 & 0.058 & 0.091 & 0.091 & 0.407 & 0.407 \\
\hline$p$-value & 0.810 & 0.764 & 0.764 & 0.523 & 0.523 \\
\hline \multicolumn{6}{|c|}{ c. Ramsey RESET test } \\
\hline F- statistic & & 0.890 & 0.890 & 0.580 & 0.580 \\
\hline Prob $>F$ & & 0.4469 & 0.4469 & 0.6298 & 0.6298 \\
\hline \multicolumn{6}{|c|}{ d. Structural Break: Unknown break date } \\
\hline wald & 15.132 & 25.278 & 25.278 & 21.183 & 21.183 \\
\hline p-value & 0.2284 & 0.0501 & 0.0501 & 0.1634 & 0.1634 \\
\hline Break Date & $2008 \mathrm{~m} 6$ & $2008 \mathrm{~m} 6$ & $2008 \mathrm{~m} 6$ & $2008 \mathrm{~m} 3$ & $2008 \mathrm{~m} 3$ \\
\hline \multicolumn{6}{|c|}{ e. Normality Test: Jarque-Bera test } \\
\hline Chi2 & 3.563 & 5.390 & 5.390 & 2.513 & 2.513 \\
\hline p-value & 0.1683 & 0.0676 & 0.0676 & 0.2846 & 0.2446 \\
\hline
\end{tabular}

First, the Breusch-Pagan test of heteroscedasticity is implemented. ${ }^{5}$ The p-values are higher than 0.10 for all five models. This implies the failure to reject the null hypothesis of homoscedasticity (panel [a] in table 5).

Second, the Breusch-Godfrey Lagrange multiplier test of autocorrelation in the residuals is implemented. The null hypothesis is that there is no autocorrelation. The results from the multiplier test (panel [b] in table 5) show that for all models the null hypothesis of no autocorrelation cannot be rejected.

Third, the Ramsey RESET test is used to check for the omitted-variable bias, where the null hypothesis is that the model has no omitted variables. Panel (c) of table 5 shows that the model does not have an omitted-variable bias since the p-value is higher than the usual threshold of 0.05 (95 percent significance). The null hypothesis of omitted-variable bias or misspecification of the functional form cannot be rejected. Hence, additional variables are not required in the model.

\footnotetext{
${ }^{5}$ If the p-value is below a certain threshold (common choices are $0.01,0.05$, and 0.10 ) then there is sufficient evidence to say that heteroscedasticity is present.
} 
Fourth, panel (d) of table 5 presents structural break tests. The null hypothesis of no structural break in the intercept when there is no break in any other coefficient in all the models cannot be rejected.

Fifth, the cumulative sum of residuals (CUSUM), proposed by Brown, Durbin, and Evans (1975), is employed to investigate the stability of the estimated coefficients attached to the cointegrating vector and the error correction terms. Figure 12 plots the recursive CUSUM to detect if there are any signs of the structural break. These figures show that CUSUM statistics are within the 95 percent confidence bands. This implies that there is no evidence of any statistically significant breaks. Figures showing the cumulative of squared residuals (CUSUMSQ) for the same models are available upon request.

Finally, panel (e) of table 5 presents the normality test for residuals based on the Jarque-Bera (JB) test. The null hypothesis is that the residuals are normally distributed. From panel (e) it is evident that for all the models the null hypothesis that the residuals are normally distributed cannot be rejected, as the p-value is larger than 0.05 . Therefore, it is concluded that there is no violation of the error term's normal distribution. Figure 13 presents the density plots of the residuals for all the models, which gives a visual representation of the residuals. These figure shows that the residuals appear to be normally distributed. 
Figure 12. Cumulative Sum of Residuals Test for Parameter Stability

Model 1

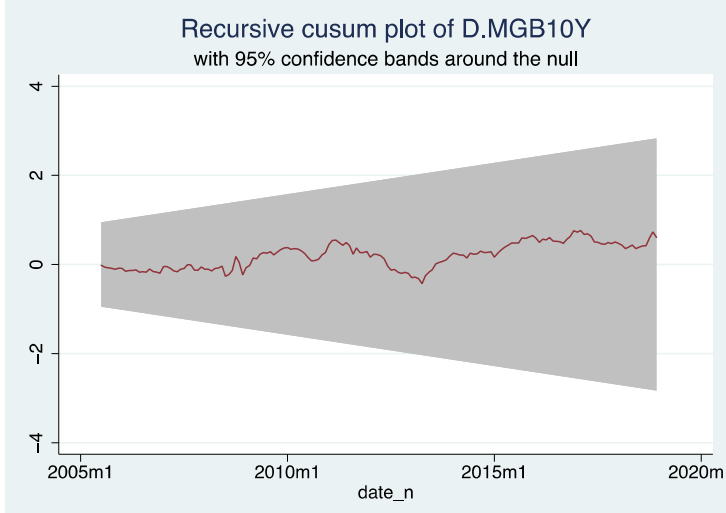

Model 3

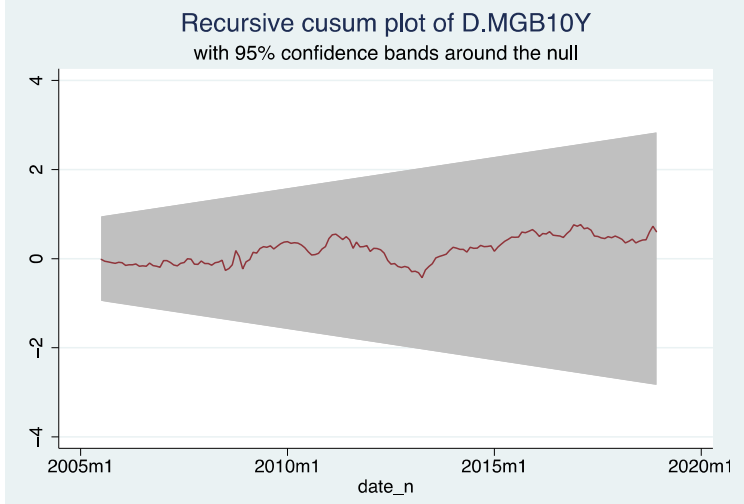

\section{Model 5}

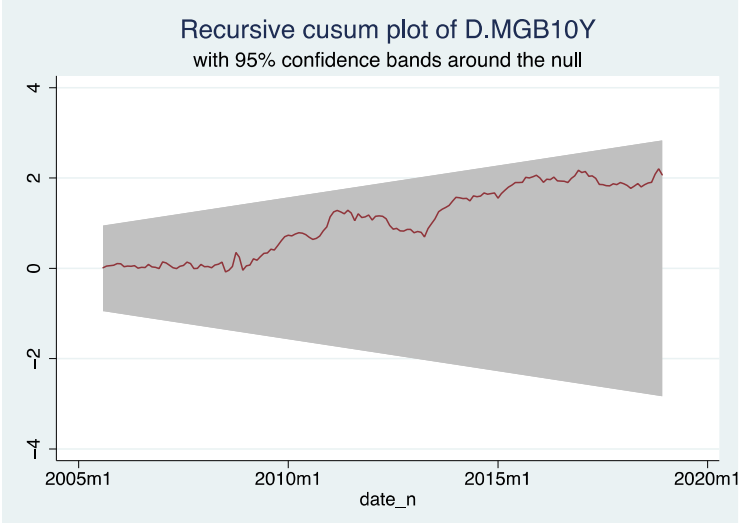

Model 2

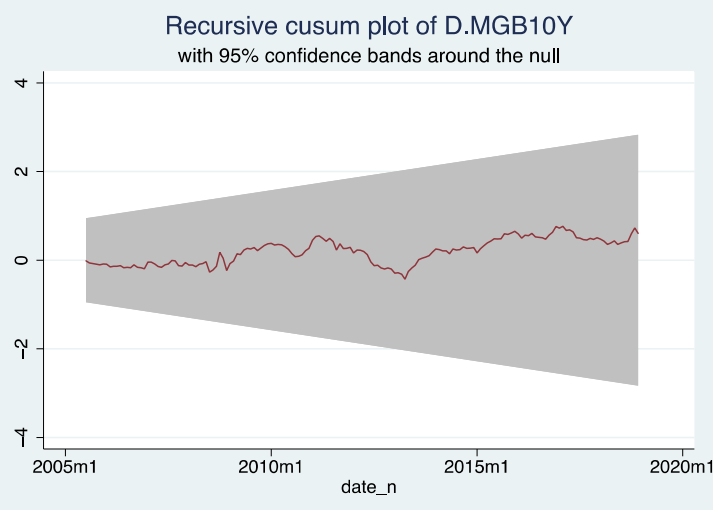

Model 4

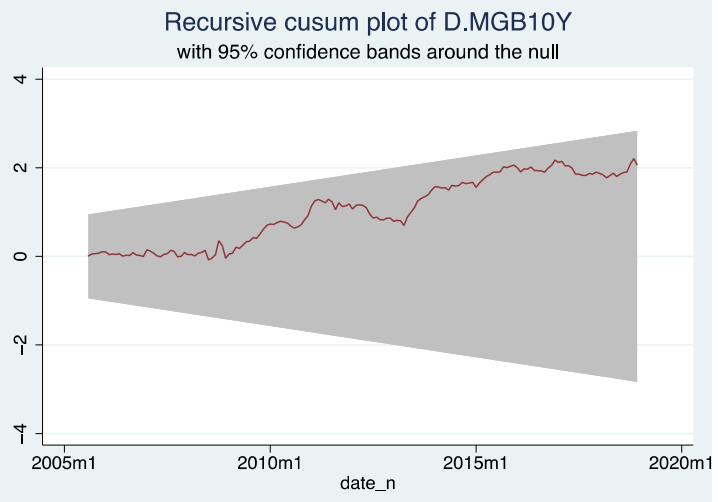


Figure 13. Residual-based Normality Plots for MGB10Y, CETES3M, CCPI, and IP

Model 1

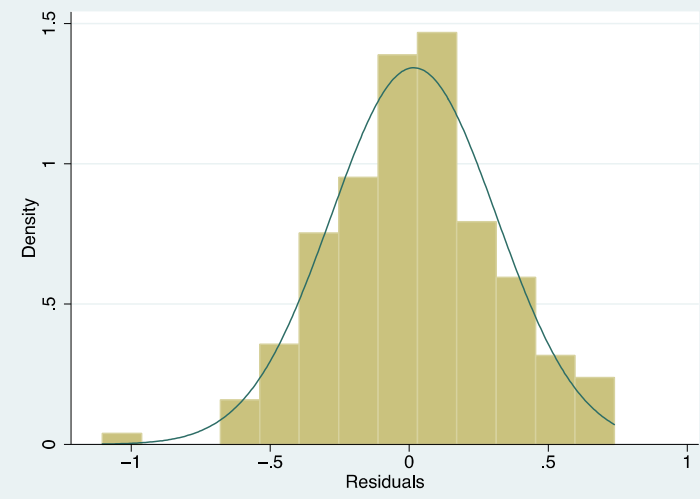

Model 3

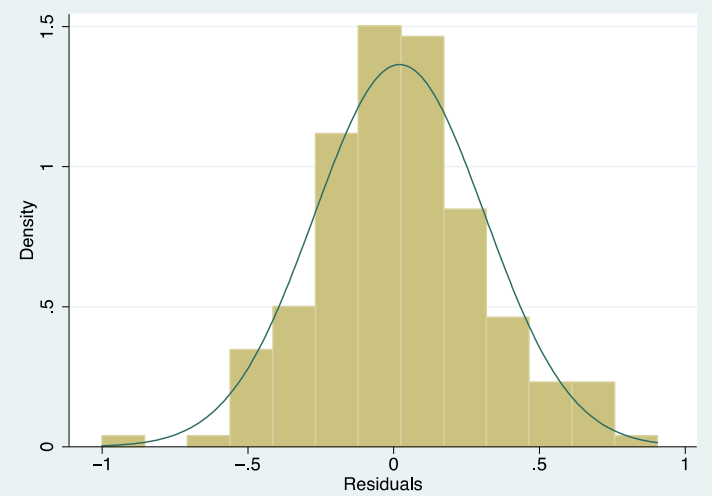

Model 2

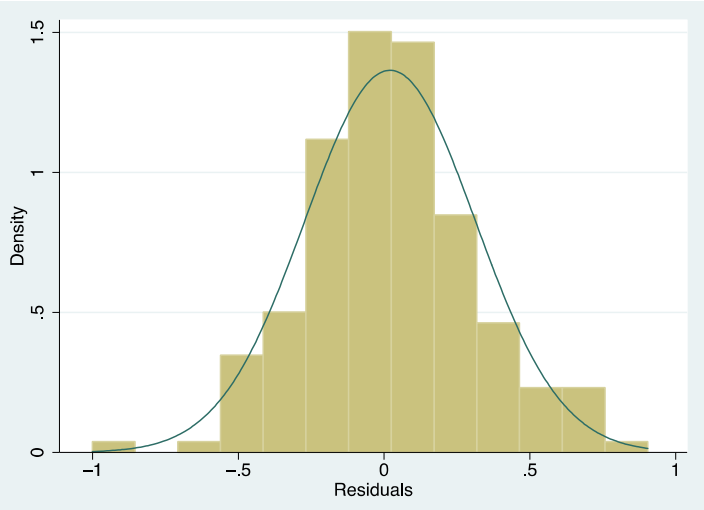

Model 4

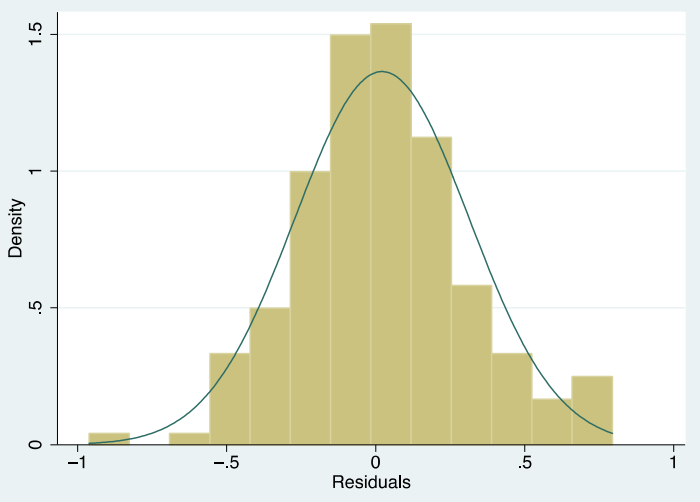

Model 5

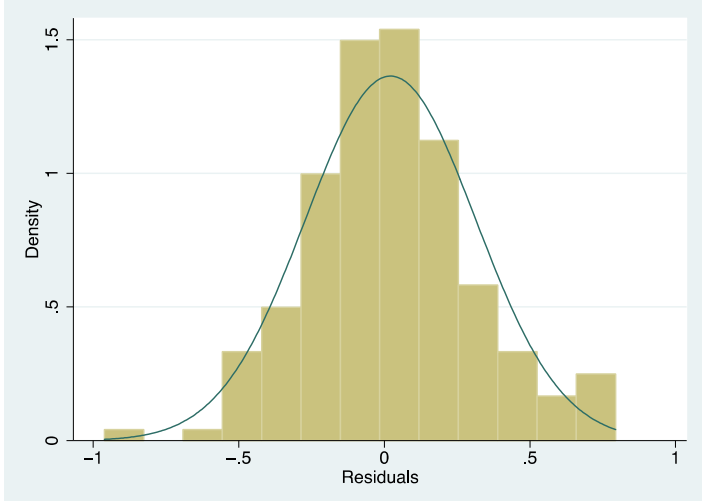




\section{Robustness Check: Using MGB5Y as a Dependent Variable}

In order to check the estimation's robustness, bond yields of a different maturity tenor (namely, MGB5Y instead of MGB10Y) will be used to estimate the model while keeping all the independent variables same as before. ${ }^{6}$ The following regression for MGB5Y using an ARDL model is estimated: ${ }^{7}$

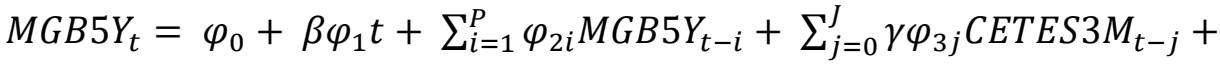

$$
\begin{aligned}
& \sum_{k=0}^{K} \gamma \varphi_{4} l C C P I_{t-k}+\sum_{l=0}^{L} \gamma \varphi_{5 l} I P_{t-l}+\varepsilon_{t} \ldots \ldots \ldots .
\end{aligned}
$$

From table 6 in model 1, the F-value is in between the upper and lower bound of critical Fvalues at the 1 percent of level of significance, while the calculated F-values are higher than the upper bound of F-values at the 5 percent and 10 percent significance levels, thus the null hypothesis of no level relationship in the long run can be rejected. For models $2-5$, the calculated F-values are higher than the upper bound of F-values at the 1 percent, 5 percent, and 10 percent significance levels. Thus, one can reject the null hypothesis of no level relationship in the long run. Besides the F-test, the values of the t-statistic from the bounds test also confirm the evidence of a long-run level relationship among the variables. Except for model 1 , all other variables have calculated t-values higher than critical t-values at the 5 percent and 10 percent significance levels.

Tables $7 \mathrm{a}$ and $7 \mathrm{~b}$ present the estimation of VEC models using the cointegrating bounds test. Table 7a presents the long-run coefficients of the estimated models, while table $7 \mathrm{~b}$ presents the short-run coefficients and the adjustment coefficients from the short- to long-run equilibrium for the same models. From table 7a, for all five models the main variable of concern - the short-term interest rate (CETES3M) - is positively related to the MGB5Y yield with an estimated elasticity ranging from 0.59 to 0.75 . This indicates that a 1 percentage point increase in the short-term interest rate is associated with a long-run increase of around 59 to

\footnotetext{
${ }^{6}$ The robustness check is also conducted using an MGB of another maturity tenor, namely MGB3Y. Additional results using MGB3Y are provided in appendix B.

${ }^{7}$ For the long-run estimation, the following equation is used:

$$
M G B 5 Y_{t}=d_{0}+d_{1} M G B 5 Y_{t-1}+d_{2} \text { CETES } 3 M_{t-1}+d_{3} C C P I_{t-1}+d_{4} I P_{t-1}+\eta_{t}
$$
}

For the short-run estimation, the following equation is used:

$$
\Delta M G B 5 Y_{t}=d_{5}+\sum_{i=1}^{P} d_{6 i} \Delta M G B 5 Y_{t-i}+\sum_{j=0}^{J} d_{7 j} \Delta C E T E S 3 M_{t-j}+\sum_{l=0}^{K} d_{8 k} \Delta C C P I_{t-k}+\sum_{k=0}^{L} d_{9 l} \Delta I P_{t-l}+\varepsilon_{t}
$$


75 basis points in MGB5Y yields. Core consumer price inflation and the growth of industrial production are negatively correlated (except for model 1) with the MGB5Y's yield with the estimated elasticities ranging from 0.097 to 0.616 and 0.14 to 0.44 , respectively. 
Table 6. Pesaran, Shin, and Smith (2001) Bounds Test for MGB5Y

\begin{tabular}{|c|c|c|c|c|c|c|c|c|c|c|c|}
\hline & & \multicolumn{2}{|c|}{ Model 1} & \multicolumn{2}{|c|}{ Model 2} & \multicolumn{2}{|c|}{ Model 3} & \multicolumn{2}{|c|}{ Model 4} & \multicolumn{2}{|c|}{ Model 5} \\
\hline & & $\mathrm{F}$ & $\mathrm{t}$ & $\mathrm{F}$ & $\mathrm{t}$ & $\mathrm{F}$ & $\mathrm{t}$ & $\mathrm{F}$ & $\mathrm{t}$ & $\mathrm{F}$ & $\mathrm{t}$ \\
\hline \multirow{2}{*}{$\begin{array}{l}\text { Calculated value } \\
10 \text { percent }\end{array}$} & & 4.052 & -1.875 & 5.075 & -3.299 & 6.312 & -3.299 & 4.847 & -4.428 & 5.916 & -4.428 \\
\hline & Lower bound & 2.003 & -1.610 & 2.368 & -2.539 & 2.711 & -2.539 & 2.987 & -3.120 & 3.492 & -3.120 \\
\hline \multirow[t]{2}{*}{5 percent } & Lower bound & 2.447 & -1.940 & 2.782 & -2.846 & 3.225 & -2.846 & 3.444 & -3.415 & 4.063 & -3.415 \\
\hline & Upper bound & 3.663 & -3.299 & 3.712 & -3.730 & 4.400 & -3.730 & 4.301 & -4.148 & 5.14 & -4.148 \\
\hline \multirow[t]{2}{*}{1 percent } & Lower bound & 3.444 & -2.578 & 3.691 & -3.443 & 4.357 & -3.443 & 4.437 & -3.992 & 5.305 & -3.992 \\
\hline & Upper bound & 4.863 & -3.947 & 4.758 & -4.364 & 5.710 & -4.364 & 5.408 & -4.764 & 6.531 & -4.764 \\
\hline \multirow{2}{*}{ p-value } & Lower bound & 0.004 & 0.058 & 0.001 & 0.015 & 0.001 & 0.015 & 0.005 & 0.002 & 0.004 & 0.002 \\
\hline & Upper bound & 0.030 & 0.430 & 0.006 & 0.119 & 0.005 & 0.119 & 0.023 & 0.025 & 0.021 & 0.025 \\
\hline
\end{tabular}

Note 1: $\mathrm{H}_{0}$ : no level relationship.

Note 2: Dependent variable is MGB10Y and independent variables are CETES3M, CCPI, and IP.

Note 3: Model 1: no intercept and no trend; Model 2: restricted intercept and no trend; Model 3: unrestricted and no trend; Model 4: unrestricted intercept and trend; and Model 5: unrestricted intercept and trend. 
Table 7a. Long-run Relationship between MGB5Y and CETES3M

\begin{tabular}{lccccc}
\hline & Model 1 & Model 2 & Model 3 & Model 4 & Model 5 \\
\cline { 2 - 6 } CETES3M & $0.745^{* *}$ & $0.670^{* * *}$ & $0.670^{* * *}$ & $0.586^{* * *}$ & $0.586^{* * * *}$ \\
& $(0.260)$ & $(0.088)$ & $(0.088)$ & $(0.078)$ & $(0.078)$ \\
CCPI & 0.616 & -0.0874 & -0.0874 & -0.0979 & -0.0979 \\
& $(0.363)$ & $(0.192)$ & $(0.192)$ & $(0.145)$ & $(0.145)$ \\
IP & -0.445 & $-0.228^{* *}$ & $-0.228^{* *}$ & $-0.141^{* *}$ & $-0.141^{* *}$ \\
& $(0.324)$ & $(0.082)$ & $(0.082)$ & $(0.047)$ & $(0.047)$ \\
Trend & & & & -0.004 & \\
& & & & $(0.003)$ & \\
Constant & & $3.396^{* * *}$ & & & \\
& & $(0.768)$ & & & 168 \\
\hline$N$ & 168 & 168 & 168 & 168 & 0.350 \\
Adj. $R^{2}$ & 0.350 & 0.380 & 0.380 & 0.350 &
\end{tabular}

Note 1: Standard errors in parentheses, ${ }^{*} p<0.05,{ }^{* *} p<0.01,{ }^{* * *} p<0.001$.

Note 2: Dependent variable is MGB5Y and independent variables are CETES3M, CCPI, and IP.

Note 3: Model 1: no intercept and no trend; Model 2: restricted intercept and no trend; Model 3: unrestricted and no trend; Model 4: unrestricted intercept and trend; and Model 5: unrestricted intercept and trend. 
Table 7b. Short-run Relationship between MGB5Y and CETES3M

\begin{tabular}{|c|c|c|c|c|c|}
\hline & Model 1 & Model 2 & Model 3 & Model 4 & Model 5 \\
\hline $\begin{array}{l}\text { Speed of adjustment } \\
\text { MGB5Y(-1) }\end{array}$ & $\begin{array}{c}-0.047 \\
(0.0249)\end{array}$ & $\begin{array}{l}-0.139^{* *} \\
(0.0420)\end{array}$ & $\begin{array}{l}-0.139^{* *} \\
(0.0420)\end{array}$ & $\begin{array}{l}-0.194^{* * *} \\
(0.0438)\end{array}$ & $\begin{array}{l}-0.194^{* * *} \\
(0.0438) \\
\end{array}$ \\
\hline $\begin{array}{l}\text { Short-run dynamics } \\
\Delta \text { MGB5Y(1) }\end{array}$ & $\begin{array}{l}-0.199^{* *} \\
(0.0662)\end{array}$ & $\begin{array}{l}-0.166^{*} \\
(0.0668)\end{array}$ & $\begin{array}{l}-0.166^{*} \\
(0.0668)\end{array}$ & & \\
\hline$\Delta$ MGB5Y $(-2)$ & $\begin{array}{l}-0.216^{* *} \\
(0.0648)\end{array}$ & $\begin{array}{l}-0.188^{* *} \\
(0.0648)\end{array}$ & $\begin{array}{l}-0.188^{* *} \\
(0.0648)\end{array}$ & & \\
\hline$\triangle \mathrm{MGB} 5 \mathrm{Y}(-3)$ & $\begin{array}{c}-0.105 \\
(0.0685)\end{array}$ & $\begin{array}{c}-0.078 \\
(0.0678)\end{array}$ & $\begin{array}{c}-0.078 \\
(0.0678)\end{array}$ & & \\
\hline$\triangle \mathrm{MGB} 5 \mathrm{Y}(-4)$ & $\begin{array}{l}-0.155^{*} \\
(0.0653)\end{array}$ & $\begin{array}{l}-0.145^{*} \\
(0.0642)\end{array}$ & $\begin{array}{l}-0.145^{*} \\
(0.0642)\end{array}$ & & \\
\hline$\Delta$ MGB5Y $(-5)$ & $\begin{array}{l}-0.106 \\
(0.0654)\end{array}$ & $\begin{array}{c}-0.111 \\
(0.0652)\end{array}$ & $\begin{array}{c}-0.111 \\
(0.0652)\end{array}$ & & \\
\hline$\Delta$ MGB5Y $(-6)$ & $\begin{array}{l}-0.176^{* *} \\
(0.0650)\end{array}$ & $\begin{array}{l}-0.153^{*} \\
(0.0642)\end{array}$ & $\begin{array}{l}-0.153^{*} \\
(0.0642)\end{array}$ & & \\
\hline$\Delta \mathrm{MGB} 5 \mathrm{Y}(-7)$ & $\begin{array}{c}-0.099 \\
(0.0653)\end{array}$ & $\begin{array}{c}-0.078 \\
(0.0644)\end{array}$ & $\begin{array}{c}-0.078 \\
(0.0644)\end{array}$ & & \\
\hline$\triangle \mathrm{MGB} 5 \mathrm{Y}(-8)$ & $\begin{array}{l}-0.159^{*} \\
(0.0654)\end{array}$ & $\begin{array}{l}-0.145^{*} \\
(0.0642)\end{array}$ & $\begin{array}{l}-0.145^{*} \\
(0.0642)\end{array}$ & & \\
\hline$\Delta$ MGB5Y(-9) & $\begin{array}{c}-0.097 \\
(0.0628)\end{array}$ & $\begin{array}{c}-0.104 \\
(0.0618)\end{array}$ & $\begin{array}{c}-0.104 \\
(0.0618)\end{array}$ & & \\
\hline$\triangle \mathrm{CETES} 3 \mathrm{M}$ & $\begin{array}{l}0.950^{* * *} \\
(0.1070)\end{array}$ & $\begin{array}{l}0.891^{* * *} \\
(0.1080)\end{array}$ & $\begin{array}{l}0.891^{* * *} \\
(0.1080)\end{array}$ & $\begin{array}{l}0.805^{* * *} \\
(0.1050)\end{array}$ & $\begin{array}{l}0.805^{* * *} \\
(0.1050)\end{array}$ \\
\hline$\triangle$ CETES3M(-1) & & & & $\begin{array}{l}-0.237^{*} \\
(0.1080)\end{array}$ & $\begin{array}{l}-0.237^{*} \\
(0.1080)\end{array}$ \\
\hline$\Delta \mathrm{IP}$ & & $\begin{array}{c}0.032 \\
(0.0171)\end{array}$ & $\begin{array}{c}0.032 \\
(0.0171)\end{array}$ & $\begin{array}{c}0.030 \\
(0.0170)\end{array}$ & $\begin{array}{c}0.030 \\
(0.0170)\end{array}$ \\
\hline Trend & & & & & $\begin{array}{c}-0.009 \\
(0.0006)\end{array}$ \\
\hline Constant & & & $\begin{array}{c}0.470^{*} \\
(0.1820)\end{array}$ & $\begin{array}{c}1.274^{*} \\
(0.5040)\end{array}$ & $\begin{array}{c}1.274^{*} \\
(0.5040)\end{array}$ \\
\hline $\begin{array}{l}N \\
\text { Adj. } R^{2} \\
\text { ARDL Lag Structure }\end{array}$ & 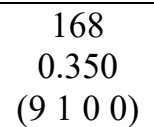 & 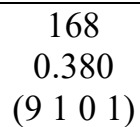 & 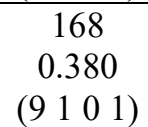 & $\begin{array}{c}168 \\
0.350 \\
(9201)\end{array}$ & $\begin{array}{c}168 \\
0.350 \\
(9201)\end{array}$ \\
\hline
\end{tabular}

Note 1: Standard errors in parentheses, ${ }^{*} p<0.05,{ }^{* *} p<0.01,{ }^{* * *} p<0.001$.

Note 2: Dependent variable is MGB5Y and independent variables are CETES3M, CCPI, IP.

Note 3: Model 1: no intercept and no trend; Model 2: restricted intercept and no trend; Model 3: unrestricted and no trend; Model 4: unrestricted intercept and trend; and Model 5: unrestricted intercept and trend.

The coefficients of the error correction term in the long-term interest rate equation are significant at the 1 percent level with the expected negative sign (table $7 \mathrm{~b}$ ). This confirms the results of the bounds test for cointegration, except for model 1 . The coefficients of the error correction term range from 0.139 to 0.194 . This implies that about 16 percent (14-19 percent) of disequilibria caused by shocks to the short-term interest rate, inflation, and economic activity is corrected within one month. The results of the short-run error correction model are presented in the panel of short-run coefficients in table $7 \mathrm{~b}$. Most of the short-run coefficients 
are significant, except for a few lagged differences in short-term interest rates. The signs of the short-run dynamic impacts are consistent with the long-run results. It is evident from table $7 \mathrm{~b}$ that models 1-3 include 9 lags in their different form, but no lags for independent variables; among the 9 lags, the 1st, 2nd, 4th, 6th, and 8th lags are statistically significant. Several diagnostic tests are presented in table 8 to assess misspecifications, autocorrelation, and heteroscedasticity in the estimated models.

Table 8. Parameter Stability Tests for MGB5Y Using Equation [9]

\begin{tabular}{|c|c|c|c|c|c|}
\hline & Model 1 & Model 2 & Model 3 & Model 4 & Model 5 \\
\hline \multicolumn{6}{|c|}{ a. Breusch-Pagan test for heteroscedasticity } \\
\hline $\operatorname{chi} 2$ & & 1.690 & 1.690 & 0.810 & 0.810 \\
\hline Prob $>$ chi 2 & & 0.1933 & 0.1933 & 0.3678 & 0.3678 \\
\hline \multicolumn{6}{|c|}{ b. Breusch-Godfrey test for autocorrelation } \\
\hline chi2 & 0.004 & 0.445 & 0.445 & 0.067 & 0.067 \\
\hline Prob $>$ chi2 & 0.94471 & 0.5047 & 0.5047 & 0.7964 & 0.7964 \\
\hline \multicolumn{6}{|c|}{ c. Ramsey RESET test } \\
\hline F- statistic & & 0.620 & 0.620 & 0.570 & 0.570 \\
\hline Prob $>$ F & & 0.6014 & 0.6014 & 0.6331 & 0.6331 \\
\hline \multicolumn{6}{|c|}{ d. Structural Break: Unknown break date } \\
\hline wald & 30.172 & 30.790 & 30.790 & 27.070 & 27.070 \\
\hline p-value & 0.1160 & 0.1976 & 0.1976 & 0.0282 & 0.0282 \\
\hline Break date & $2009 \mathrm{~m} 1$ & $2009 \mathrm{~m} 1$ & $2009 \mathrm{~m} 1$ & $2011 \mathrm{~m} 8$ & $2011 \mathrm{~m} 8$ \\
\hline \multicolumn{6}{|c|}{ e. Normality: Jarque-Bera test } \\
\hline JB test stat & 41.610 & 32.700 & 32.700 & 28.570 & 28.570 \\
\hline P-value & 0.0000 & 0.0000 & 0.0000 & 0.0000 & 0.0000 \\
\hline
\end{tabular}

First, the Breusch-Pagan test of heteroscedasticity is implemented. ${ }^{8}$ The p-values are higher than 0.10 for all five models. This implies that the null hypothesis of homoscedasticity (panel [a] in table 8) cannot be rejected.

Second, the Breusch-Godfrey Lagrange multiplier test of autocorrelation in the residuals is implemented. The null hypothesis is that there is no autocorrelation. The results from the multiplier test (panel [b] in table 8) show that for all models the null hypothesis cannot be rejected.

\footnotetext{
${ }^{8}$ If the p-value is below a certain threshold (common choices are $0.01,0.05$, and 0.10 ) then there is sufficient evidence to say that heteroscedasticity is present.
} 
Third, the Ramsey RESET test is used to check for the omitted-variable bias, where the null hypothesis is that the model has no omitted variables. Panel (c) of table 8 shows that the model does not have an omitted-variable bias: the p-value is higher than the usual threshold of 0.05 (95 percent significance). Hence, the null hypothesis cannot be rejected. It reasonable to conjecture that there is no need to add more variables to the model.

Fourth, panel (d) of table 8 presents a structural break test. The results imply a failure to reject the null hypothesis of no structural break in the intercept when there is no break in any other coefficient in all the models. ${ }^{9}$

Finally, panel (e) of table 8 presents the normality test for residuals. The null hypothesis is that the residuals are normally distributed. From panel (e) it is evident that all the models suggest rejecting the null hypothesis, as the p-value is smaller than 0.05 . Therefore, there is a violation of the normal distribution of the error terms.

\section{Alternative Models Using Total Inflation}

The analysis is checked using a model with total inflation instead of core inflation. For this alternative specification, the following equation is used to estimate the ARDL model, with MGB10Y as the dependent variable:

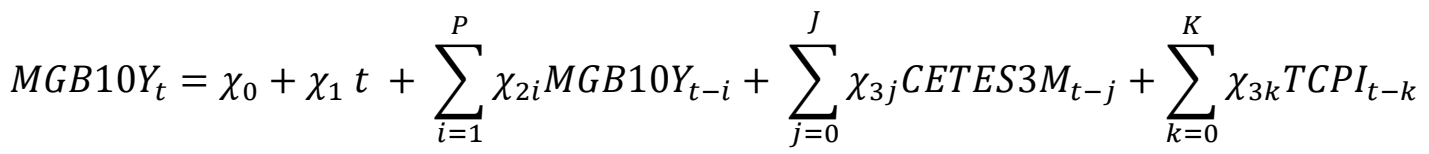

$$
\begin{aligned}
& +\sum_{l=0}^{L} \chi_{4 l} I P_{t-l}+\varepsilon_{t}
\end{aligned}
$$

Here total inflation, TCPI, is used instead of core inflation, CCPI, used earlier.

\footnotetext{
${ }^{9}$ In addition, the CUSUM and the CUSUMSQ tests are employed to investigate the stability of the estimated coefficients attached to the cointegrating vector and the error correction terms. Figures are available upon request. These results show that CUSUM and CUSUMSQ statistics are within the 95 percent confidence bands. This implies that there is no evidence of a statistically significant break.
} 
Table 9. Pesaran, Shin, and Smith (2001) Bounds Test for MGB10Y based on Equation [5]

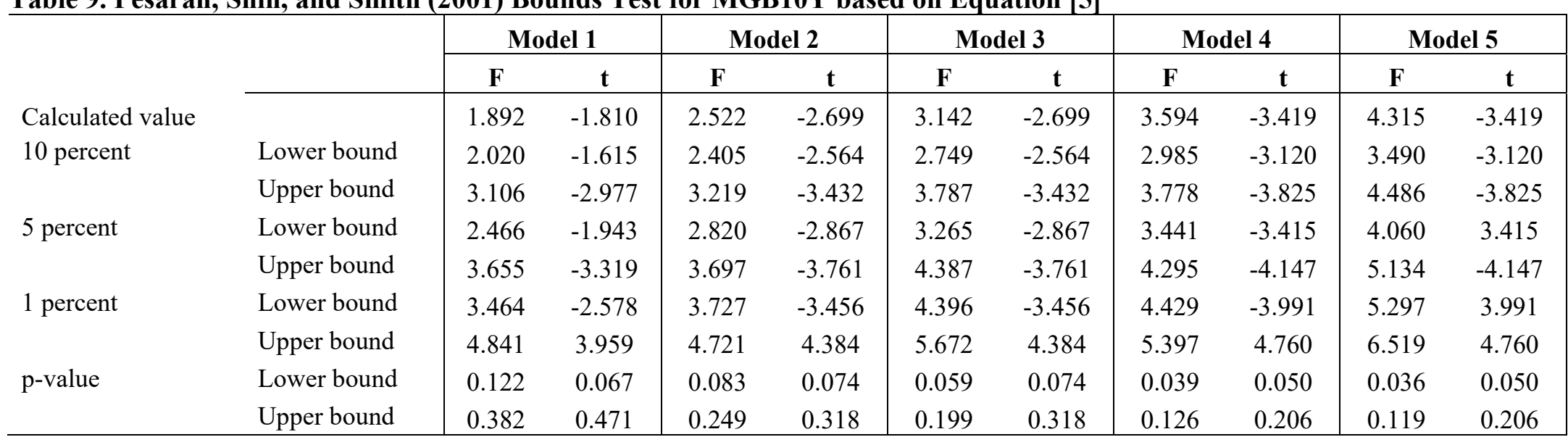

Note 1: Dependent variable is MGB10Y and independent variables are CETES3M, TCPI, and IP.

Note 2: Model 1: no intercept and no trend; Model 2: restricted intercept and no trend; Model 3: unrestricted and no trend; Model 4: unrestricted intercept and trend; and Model 5: unrestricted intercept and trend. 
Tables $10 \mathrm{a}$ and $10 \mathrm{~b}$ present the estimation of VEC models using the cointegrating bounds test.

Table 10a. Long-run Regression for MGB10Y with CETES3M, TCPI, and IP

\begin{tabular}{lccccc}
\hline & Model 1 & Model 2 & Model 3 & Model 4 & Model 5 \\
\cline { 2 - 6 } CETES3M & 0.622 & $0.563^{* *}$ & $0.563^{* *}$ & $0.459^{* * *}$ & $0.459^{* * *}$ \\
TCPI & $(0.325)$ & $(0.169)$ & $(0.169)$ & $(0.122)$ & $(0.122)$ \\
& 0.945 & -0.255 & -0.255 & -0.218 & -0.218 \\
IP & $(0.524)$ & $(0.518)$ & $(0.518)$ & $(0.332)$ & $(0.332)$ \\
& -0.199 & -0.212 & -0.212 & $-0.203^{*}$ & $-0.203^{*}$ \\
Trend & $(0.258)$ & $(0.138)$ & $(0.138)$ & $(0.089)$ & $(0.089)$ \\
& & & & $-0.009^{*}$ & \\
Constant & & & & $(0.004)$ & \\
& & $5.125^{* *}$ & & & \\
\hline$N$ & $(1.651)$ & & 177 & 177 \\
Adj. $R^{2}$ & 171 & 177 & 0.293 & 0.307 & 0.307 \\
\hline
\end{tabular}

Note 1: Standard errors in parentheses, ${ }^{*} p<0.05,{ }^{* *} p<0.01,{ }^{* * *} p<0.001$.

Note 2: Dependent variable is MGB10Y and independent variables are CETES3M, TCPI, and IP.

Note 3: Model 1: no intercept and no trend; Model 2: restricted intercept and no trend; Model 3: unrestricted and no trend; Model 4: unrestricted intercept and trend; and Model 5: unrestricted intercept and trend.

Table 10b. Short-run Adjustment Coefficients for $\triangle$ MGB10Y with $\triangle T C P I$

\begin{tabular}{|c|c|c|c|c|c|}
\hline & Model 1 & Model 2 & Model 3 & Model 4 & Model 5 \\
\hline $\begin{array}{l}\text { Speed of adjustment } \\
\text { MGB10Y(-1) }\end{array}$ & $\begin{array}{l}-0.044 \\
(0.0241)\end{array}$ & $\begin{array}{l}-0.081^{* *} \\
(0.0300)\end{array}$ & $\begin{array}{l}-0.081^{* *} \\
(0.0300)\end{array}$ & $\begin{array}{l}-0.126^{* * *} \\
(0.0368)\end{array}$ & $\begin{array}{l}-0.126^{* * *} \\
(0.0368)\end{array}$ \\
\hline \multicolumn{6}{|l|}{ Short-run dynamics } \\
\hline$\triangle$ CETES3M & $\begin{array}{l}0.768^{* * *} \\
(0.1090)\end{array}$ & $\begin{array}{l}0.780^{* * *} \\
(0.0999)\end{array}$ & $\begin{array}{l}0.780^{* * *} \\
(0.0999)\end{array}$ & $\begin{array}{l}0.822^{* * *} \\
(0.1010)\end{array}$ & $\begin{array}{l}0.822^{* * *} \\
(0.1010)\end{array}$ \\
\hline$\Delta$ CETES3M(-1) & $\begin{array}{l}-0.360^{* * *} \\
(0.1050)\end{array}$ & $\begin{array}{l}-0.362^{* * *} \\
(0.0996)\end{array}$ & $\begin{array}{l}-0.362^{* * *} \\
(0.0996)\end{array}$ & $\begin{array}{l}-0.293^{* *} \\
(0.1050)\end{array}$ & $\begin{array}{l}-0.293^{* *} \\
(0.1050)\end{array}$ \\
\hline$\Delta$ CETES3M(-2) & $\begin{array}{c}-0.152 \\
(0.1090)\end{array}$ & & & & \\
\hline$\Delta \mathrm{IP}$ & & & & $\begin{array}{c}0.0281 \\
(0.0174)\end{array}$ & $\begin{array}{c}0.0281 \\
(0.0174)\end{array}$ \\
\hline Trend & & & & & $\begin{array}{l}-0.001 \\
(0.0006)\end{array}$ \\
\hline Constant & & & $\begin{array}{c}0.415^{*} \\
(0.1640)\end{array}$ & $\begin{array}{c}1.430^{*} \\
(0.5570) \\
\end{array}$ & $\begin{array}{c}1.430^{*} \\
(0.5570) \\
\end{array}$ \\
\hline$N$ & 171 & 177 & 177 & 177 & 177 \\
\hline $\begin{array}{l}\text { Adj. } R^{2} \\
\text { ARDL Lag Structure }\end{array}$ & $\begin{array}{c}0.249 \\
(1,3,0,0)\end{array}$ & $\begin{array}{c}0.293 \\
(1,2,0,0)\end{array}$ & $\begin{array}{c}0.293 \\
(1,2,0,0)\end{array}$ & $\begin{array}{c}0.307 \\
(1,2,0,1)\end{array}$ & $\begin{array}{c}0.307 \\
(1,2,0,1)\end{array}$ \\
\hline
\end{tabular}

Note 1: Standard errors in parentheses, ${ }^{*} p<0.05,{ }^{* *} p<0.01,{ }^{* * *} p<0.001$.

Note 2: Dependent variable is MGB10Y and independent variables are CETES3M, TCPI, and IP.

Note 3: Model 1: no intercept and no trend; Model 2: restricted intercept and no trend; Model 3: unrestricted and no trend; Model 4: unrestricted intercept and trend; and Model 5: unrestricted intercept and trend. 
Table 10a presents the long-run coefficients of the estimated models, while table 10b presents the short-run coefficients and the adjustment coefficients from the short- to long-run equilibrium for the same models. From table 10a, for all five models the main variableshort-term interest rates (CETES3M) - is positively related to the MGB10Y yield with an estimated elasticity ranging from 0.46 to 0.62 . This indicates that a 1 percentage point increase in the short-term interest rate causes a long-run increase of around 46 to 62 basis points in the government treasury bonds rate. The total consumer price index and industrial production index are negatively correlated (except for model 1) with the government bond yields, with the estimated elasticities ranging from 0.21 to 0.25 and 0.20 to 0.22 , respectively.

The coefficients of the error correction term are statistically significant at the 5 percent level with the expected negative sign, except in model 1 (table 10b). The coefficients of the error correction term range from 0.08 to 0.13 , implying that about 10 percent ( $8-13$ percent) of disequilibria caused by shocks to the short-term interest rate, inflation, and growth of industrial production is corrected within one month. Most of the short-run coefficients are significant, except for a few lagged differences in the short-term interest rate.

Table 11 displays several diagnostic tests to assess misspecifications, autocorrelations, and heteroscedasticity. 
Table 11. Parameter Stability Test for MGB10Y Using Equation [10] Model $1 \quad$ Model 2 Model $3 \quad$ Model $4 \quad$ Model 5

\section{a. Breusch-Pagan test for heteroscedasticity}

\begin{tabular}{lcccc} 
chi2 & 0.080 & 0.080 & 0.000 & 0.000 \\
Prob $>$ chi2 & 0.7830 & 0.7830 & 0.9479 & 0.9479 \\
\hline
\end{tabular}

\section{b. Breusch-Godfrey test for autocorrelation}

\begin{tabular}{lccccc} 
chi2 & 0.034 & 0.059 & 0.059 & 0.536 & 0.536 \\
Prob > chi2 & 0.8534 & 0.8084 & 0.8084 & 0.4642 & 0.4642 \\
\hline
\end{tabular}

c. Ramsey RESET Test

\begin{tabular}{lcccc} 
F- statistic & 1.260 & 1.260 & 1.430 & 1.430 \\
Prob > F & 0.2903 & 0.2903 & 0.2352 & 0.2352 \\
\hline
\end{tabular}

d. Structural Break: Unknown break date

\begin{tabular}{lccccc} 
wald & 24.925 & 38.112 & 38.112 & 40.655 & 40.655 \\
p-value & 0.0175 & 0.0001 & 0.0001 & 0.0002 & 0.0002 \\
Break date & $2008 \mathrm{~m} 7$ & $2006 \mathrm{~m} 7$ & $2006 \mathrm{~m} 7$ & $2007 \mathrm{~m} 1$ & $2007 \mathrm{~m} 1$ \\
\hline
\end{tabular}

e. Normality test: Jarque-Bera test

\begin{tabular}{lccccc} 
Test stat & 7.362 & 2.305 & 2.305 & 2.158 & 2.158 \\
P-value & 0.0252 & 0.3159 & 0.3159 & 0.3399 & 0.3399 \\
\hline
\end{tabular}

Note 1: Dependent variable is MGB10Y and independent variables are CETES3M, TCPI, and IP.

Note 2: Model 1: no intercept and no trend; Model 2: restricted intercept and no trend; Model 3: unrestricted and no trend; Model 4: unrestricted intercept and trend; and Model 5: unrestricted intercept and trend. 
First, the Breusch-Pagan test of heteroscedasticity (panel [a] in table 11) is implemented. The p-values are higher than 0.10 for all five models. The null hypothesis of homoscedasticity cannot be rejected.

Second, the Breusch-Godfrey Lagrange multiplier test of autocorrelation (panel [b] in table 11) in the residuals is implemented. The null hypothesis is that there is no autocorrelation. The results from the multiplier test show that for all models the null hypothesis cannot be rejected.

Third, the Ramsey RESET is used to test to check for the omitted-variable bias. In panel (c) of table 11 , the p-value is higher than the usual threshold of 0.05 (95 percent significance). It shows that the null hypothesis that the model does not have an omitted-variable bias cannot be rejected. There is no need for more variables in the model.

Fourth, panel (d) of table 11 presents a structural break test. The null hypothesis of no structural break in the intercept when there is no break in any other coefficient in all the models can be rejected.

Finally, panel (e) of table 11 presents the normality test for residuals. The null hypothesis is that the residuals are normally distributed. It is evident that all the null hypotheses can be rejected, as the p-value is smaller than 0.05 . Therefore, there is a violation of the normal distribution of the error terms.

A similar exercise is conducted with MGB5Y as the dependent variables and TCPI as an independent variable using the equation given below.

$$
\begin{aligned}
\operatorname{MGBSY}_{t}=\alpha & +\beta_{1} \text { MGB5Y }_{t-1}+\beta_{2}{\text { CETES } 3 M_{t-1}+\beta_{3} \text { TCPI }_{t-1}+\beta_{4} I P_{t-1}} \\
& +\sum_{i=1}^{P} \gamma_{1} \Delta M G B 10 Y_{t-i}+\sum_{j=0}^{J} \gamma_{2} \Delta C E T E S 3 M_{t-j}+\sum_{K=0}^{K} \gamma_{3} \Delta T C P I_{t-k} \\
& +\sum_{l=0}^{L} \gamma_{4} \Delta I P_{t-l}+\varepsilon_{t}
\end{aligned}
$$


The results are provided in table 12 , table 13 , and table 14 but are not described in detail.

Suffice to say, the results are similar, which further corroborates that the findings are robust. 
Table 12. Pesaran, Shin, and Smith (2001) Bounds Test for MGB5Y, CETES3M, TCPI, and IP

\begin{tabular}{|c|c|c|c|c|c|c|c|c|c|c|c|}
\hline & & \multicolumn{2}{|c|}{ Model 1} & \multicolumn{2}{|c|}{ Model 2} & \multicolumn{2}{|c|}{ Model 3} & \multicolumn{2}{|c|}{ Model 4} & \multicolumn{2}{|c|}{ Model 5} \\
\hline & & $\mathrm{F}$ & $\mathrm{t}$ & $\mathrm{F}$ & $\mathrm{t}$ & $\mathrm{F}$ & $\mathrm{t}$ & $\mathrm{F}$ & $\mathrm{t}$ & $\mathrm{F}$ & $\mathrm{t}$ \\
\hline \multirow{3}{*}{$\begin{array}{l}\text { Calculated value } \\
10 \text { percent }\end{array}$} & & 3.775 & -1.141 & 3.019 & -3.273 & 3.773 & -3.273 & 4.499 & -4.169 & 5.538 & -4.169 \\
\hline & Lower bound & 2.006 & -1.610 & 2.405 & -2.564 & 2.749 & -2.564 & 2.985 & -3.120 & 3.490 & -3.120 \\
\hline & Upper bound & 3.109 & -2.958 & 3.219 & -3.432 & 3.787 & -3.432 & 3.778 & -3.825 & 4.486 & -3.825 \\
\hline \multirow{2}{*}{5 percent } & Lower bound & 2.449 & -1.940 & 2.820 & -2.867 & 3.265 & -2.867 & 3.441 & -3.415 & 4.06 & -3.415 \\
\hline & Upper bound & 3.661 & -3.302 & 3.697 & -3.761 & 4.387 & -3.761 & 4.295 & -4.147 & 5.134 & -4.147 \\
\hline \multirow[t]{2}{*}{1 percent } & Lower bound & 3.446 & -2.578 & 3.727 & -3.456 & 4.396 & -3.456 & 4.429 & -3.991 & 5.297 & -3.991 \\
\hline & Upper bound & 4.858 & -3.948 & 4.721 & -4.384 & 5.672 & -4.384 & 5.397 & -4.760 & 6.519 & -4.760 \\
\hline \multirow[t]{2}{*}{ p-value } & Lower bound & 0.006 & 0.226 & 0.035 & 0.017 & 0.025 & 0.017 & 0.009 & 0.006 & 0.007 & 0.006 \\
\hline & Upper bound & 0.043 & 0.701 & 0.132 & 0.134 & 0.102 & 0.134 & 0.038 & 0.047 & 0.032 & 0.047 \\
\hline
\end{tabular}

Note 1: Dependent variable is MGB5Y and independent variables are CETES3M, TCPI, and IP.

Note 2: Model 1: no intercept and no trend; Model 2: restricted intercept and no trend; Model 3: unrestricted and no trend; Model 4: unrestricted intercept and trend; and Model 5: unrestricted intercept and trend. 
Table 13a. Long-run Regression for MGB5Y with CETES3M, TCPI, and IP

\begin{tabular}{llllll}
\hline & \multicolumn{1}{c}{ Model 1 } & \multicolumn{1}{c}{ Model 2 } & \multicolumn{1}{c}{ Model 3 } & \multicolumn{1}{c}{ Model 4 } & \multicolumn{1}{c}{ Model 5 } \\
\cline { 2 - 6 } CETES3M & 0.885 & $0.633^{* * *}$ & $0.633^{* * *}$ & $0.550^{* * *}$ & $0.550^{* * *}$ \\
\multirow{2}{*}{ TCPI } & $(0.4670)$ & $(0.1150)$ & $(0.1150)$ & $(0.0853)$ & $(0.0853)$ \\
& 0.468 & -0.106 & -0.106 & -0.111 & -0.111 \\
IP & $(0.7200)$ & $(0.3450)$ & $(0.3450)$ & $(0.2300)$ & $(0.2300)$ \\
& -0.655 & -0.143 & -0.143 & $-0.154^{* *}$ & $-0.154^{* *}$ \\
Trend & $(0.7030)$ & $(0.0855)$ & $(0.0855)$ & $(0.0582)$ & $(0.0582)$ \\
& & & & $-0.008^{* *}$ & \\
Constant & & & $(0.0029)$ & \\
\multirow{2}{*}{$N$} & & $3.662^{* *}$ & & & \\
Adj. $R^{2}$ & 171 & $(1.0980)$ & & 177 & 177 \\
\hline
\end{tabular}

Note 1: Standard errors in parentheses, ${ }^{*} p<0.05,{ }^{* *} p<0.01,{ }^{* * *} p<0.001$.

Note 2: Dependent variable is MGB5Y and independent variables are CETES3M, TCPI, and IP.

Note 3: Model 1: no intercept and no trend; Model 2: restricted intercept and no trend; Model 3: unrestricted and no trend; Model 4: unrestricted intercept and trend; and Model 5: unrestricted intercept and trend. 
Table 13b. Short-run Regression for MGB5Y with CETES3M, TCPI and IP

\begin{tabular}{|c|c|c|c|c|c|}
\hline & Model 1 & Model 2 & Model 3 & Model 4 & Model 5 \\
\hline $\begin{array}{l}\text { Speed of adjustment } \\
\text { MGB5Y(-1) }\end{array}$ & $\begin{array}{c}-0.035 \\
(0.0304)\end{array}$ & $\begin{array}{l}-0.118^{* *} \\
(0.0359)\end{array}$ & $\begin{array}{l}-0.118^{* *} \\
(0.0359)\end{array}$ & $\begin{array}{l}-0.176^{* * *} \\
(0.0421)\end{array}$ & $\begin{array}{c}-0.176^{* * *} \\
(0.0421)\end{array}$ \\
\hline Short-run dynamics & & & & & \\
\hline$\Delta \operatorname{MGB} 5 \mathrm{Y}(-1)$ & $\begin{array}{l}-0.210^{* *} \\
(0.0676)\end{array}$ & & & & \\
\hline$\Delta$ MGB5Y(-2) & $\begin{array}{l}-0.210^{* *} \\
(0.0661)\end{array}$ & & & & \\
\hline$\Delta$ MGB5Y(-3) & $\begin{array}{c}-0.098 \\
(0.0684)\end{array}$ & & & & \\
\hline$\Delta$ MGB5Y(-4) & $\begin{array}{l}-0.163^{*} \\
(0.0654)\end{array}$ & & & & \\
\hline$\Delta$ MGB5Y(-5) & $\begin{array}{c}-0.104 \\
(0.0642)\end{array}$ & & & & \\
\hline$\Delta$ MGB5Y(-6) & $\begin{array}{l}-0.195^{* *} \\
(0.0623)\end{array}$ & & & & \\
\hline$\Delta$ MGB5Y(-7) & $\begin{array}{c}-0.087 \\
(0.0626)\end{array}$ & & & & \\
\hline$\Delta$ MGB5Y(-8) & $\begin{array}{l}-0.166^{* *} \\
(0.0634)\end{array}$ & & & & \\
\hline$\triangle \mathrm{CETES} 3 \mathrm{M}$ & $\begin{array}{l}0.954^{* * *} \\
(0.107)\end{array}$ & $\begin{array}{l}0.861^{* * *} \\
(0.0993)\end{array}$ & $\begin{array}{l}0.861^{* * *} \\
(0.0993)\end{array}$ & $\begin{array}{l}0.904^{* * *} \\
(0.0992)\end{array}$ & $\begin{array}{c}0.904^{* * *} \\
(0.0992)\end{array}$ \\
\hline$\triangle$ CETES3M(-1) & & $\begin{array}{l}-0.287^{* *} \\
(0.0994)\end{array}$ & $\begin{array}{l}-0.287^{* *} \\
(0.0994)\end{array}$ & $\begin{array}{l}-0.200 \\
(0.105)\end{array}$ & $\begin{array}{l}-0.200 \\
(0.105)\end{array}$ \\
\hline$\Delta \mathrm{IP}$ & & & & $\begin{array}{c}0.029 \\
(0.0172)\end{array}$ & $\begin{array}{c}0.029 \\
(0.0172)\end{array}$ \\
\hline Trend & & & & & $\begin{array}{l}-0.001^{*} \\
(0.0006)\end{array}$ \\
\hline Constant & & & $\begin{array}{c}0.430^{* *} \\
(0.1560)\end{array}$ & $\begin{array}{l}1.575^{* *} \\
(0.5140) \\
\end{array}$ & $\begin{array}{l}1.575^{* *} \\
(0.5140) \\
\end{array}$ \\
\hline$N$ & 171 & 177 & 177 & 177 & 177 \\
\hline Adj. $R^{2}$ & 0.347 & 0.341 & 0.341 & 0.360 & 0.360 \\
\hline ARDL ag Structure & $(9,1,0,0)$ & $(1,2,0,0)$ & $(1,2,0,0)$ & $(1,2,0,1)$ & $(1,2,0,1)$ \\
\hline
\end{tabular}

Note 1: Standard errors in parentheses, ${ }^{*} p<0.05,{ }^{* *} p<0.01,{ }^{* * *} p<0.001$.

Note 2: Dependent variable is MGB5Y and independent variables are CETES3M, TCPI, and IP.

Note 3: Model 1: no intercept and no trend; Model 2: restricted intercept and no trend; Model 3: unrestricted and no trend; Model 4: unrestricted intercept and trend; and Model 5: unrestricted intercept and trend. 
Table 14. Parameter Stability Tests for MGB5Y, TECES3M, TCPI, and IP Model $1 \quad$ Model 2 Model $3 \quad$ Model $4 \quad$ Model 5

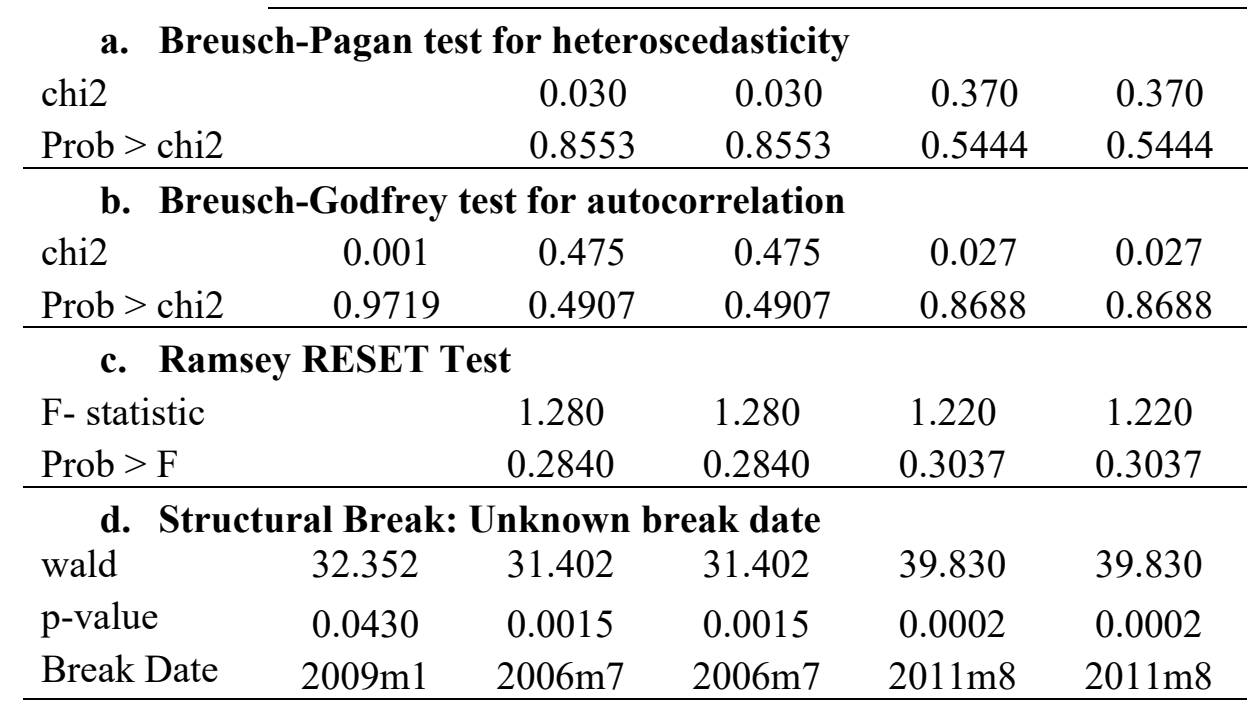

\section{e. Normality test: Jarque-Bera test}

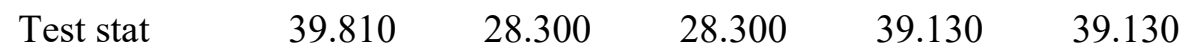

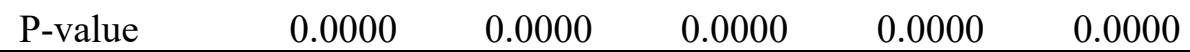

Note 1: Dependent variable is MGB5Y and independent variables are CETES3M, TCPI, and IP.

Note 2: Model 1: no intercept and no trend; Model 2: restricted intercept and no trend; Model 3: unrestricted and no trend; Model 4: unrestricted intercept and trend; and Model 5: unrestricted intercept and trend.

Additional models are estimated in appendix B. These results are broadly aligned with the findings shown in the paper.

\section{CONCLUSIONS}

The empirical results in this paper's model estimates strengthen the case that the Keynesian approach can be useful and insightful for modeling the dynamics of MGB yields. The results evince that the BdM can exert a substantial influence on long-term MGB yields. The BdM's actions appear have a decisive influence on the Treasury yield curve, as the short-term interest rate affects the long-term interest rate on MGBs of various maturity tenors. A higher (lower) short-term interest rate is associated with a higher (lower) government bond yield, after controlling for other variables such as inflation and the growth of industrial production. The BdM influences MGB yields through the effect the overnight policy rate on the shortterm interest rate, as reflected in Cetes' interest rates (ranging from 1-month to 12-month tenors). If the $\mathrm{BdM}$ is willing to keep short-term interest rates low by keeping its overnight policy rate low, then it can prevent a spike in MGB yields over the long-run horizon. The 
BdM can exert upward pressure on MGB yields over the long-run horizon by exerting pressure on the short-term interest rate through its overnight policy target rate. In particular, if the BdM controls the short-term interest rate through the overnight policy rate in combination with other instruments of monetary policy actions, such as large-scale asset purchases or sales, forward guidance, and so forth, there is no reason to doubt the central bank's ability to keep the long-term interest rate low, both over the long- and short-run horizon.

The findings discussed in the paper reveal that the BdM's monetary policy actions are a key driver of the long-term interest rate and the shape of the yield curve in Mexico. Under a regime of monetary sovereignty, the BdM has the operational ability and flexibility to effectively exercise control bond yields and the yield curve in local currency government debt. The BdM's policy rate decision is affected by: (1) the overall economic and financial conditions and inflationary pressures in Mexico, (2) the economic and financial conditions and inflationary pressures in its main trading and economic partner (the United States), and (3) the US Federal Reserve's monetary policy and the bond market. Furthermore, the BdM's statutory mandates, policy objectives, and its assessment of economic and financial conditions influence its policy decisions.

The findings from this paper can inform policy issues and discussions on monetary and fiscal policy in Mexico. They can also have policy implications for government bond yields in other emerging market countries, both in Latin America (Martinez, Tercenoa, and Teruelb 2013) and elsewhere (Jaramillo and Weber 2013).

The results obtained provide empirical information that can be useful to both long-standing debates and ongoing controversies in macroeconomic theory on a wide range of topics, such as the effects of monetary policy, quantitative easing, operational issues in central banking (Bindseil 2004; Fullwiler [2008] 2017), the fiscal theory of price (Sims 2013), the efficient market hypothesis, the government's debt sustainability (Fullwiler 2016), fiscal policy, fiscalmonetary coordination (Tcherneva 2011), functional finance (Lerner 1943, 1947), modern money and chartalism (Wray 2012), and government bond markets in emerging economics (Turner 2002). 


\section{REFERENCES}

Akram, T. 2020. “A Simple Model of the Long-Term Interest Rate.” Levy Economics Institute Working Paper No. 951 (April). Annandale-on-Hudson, NY: Levy Economics Institute of Bard College.

Akram, T., and A. Das. 2014. "Understanding the Low Yields of the Long-Term Japanese Sovereign Debt." Journal of Economic Issues 48(2): (June) 331-40.

- 2015. "A Keynesian Explanation of Indian Government Bond Yields.” Journal of Post Keynesian Economics 38(4): 565-87.

_ 2017. "The Dynamics of Government Bond Yields in the Eurozone." Annals of Financial Economics 12(3): 1750011-18.

- 2019a. "The Long-run Determinants of Indian Government Bond Yields." Asian Development Review 36(1): 168-205.

_. 2019b. "An Analysis of the Daily Changes in US Treasury Security Yields.” Levy Institute Working Paper No. 934. Annandale-on-Hudson, NY: Levy Economics Institute of Bard College.

— 2020a. "The Empirics of Canadian Government Securities Yields.” Levy Institute Working Paper No. 944. Annandale-on-Hudson, NY: Levy Economics Institute of Bard College.

_. 2020b. "Australian Government Bonds' Nominal Yields: A Keynesian Perspective." Annals of Financial Economics 15(1): 2050003-1-2050003-20.

Akram, T., and H. Li. 2016. "The Empirics of Long-Term U.S. Interest Rates.” Levy Institute Working Paper No. 863. Annandale-on-Hudson, NY: Levy Economics Institute of Bard College.

- 2017. "What Keeps Long-Term U.S. Interest Rates So Low?” Economic Modelling 60 (January): 380-90.

- 2018. “The Dynamics of JGBs' Nominal Yields.” Levy Institute Working Paper No. 906. Annandale-on-Hudson, NY: Levy Economics Institute of Bard College.

- 2019. "The Impact of the Bank of Japan's Monetary Policy on Japanese Government Bonds' Low Nominal Yields.” Levy Institute Working Paper No. 938. Annandale-onHudson, NY: Levy Economics Institute of Bard College.

_. 2020a. "An Inquiry Concerning Long-Term U.S. Interest Rates Using Monthly Data." Applied Economics 52(24): 2594-621.

_. 2020b. “JGBs' Chronically Low Nominal Yields: A VEC Approach.” Applied Economics 52(53): 5873-93. 
_. 2020c. "Some Empirical Models of Japanese Government Bond Yields Using Daily Data." Levy Institute Working Paper No. 962. Annandale-on-Hudson, NY: Levy Economics Institute

Akram, T., and S. Uddin. 2020. "An Empirical Analysis of Long-Term Brazilian Interest Rates.” Levy Institute Working Paper No. 956. Annandale-on-Hudson, NY: Levy Economics Institute of Bard College.

Ardagna, S., F. Caselli, and T. Lane. 2007. "Fiscal Discipline and the Cost of Public Debt Service: Some Estimates for OECD Countries.” The B. E. Journal of Macroeconomics 7(1): 1-33.

Baldacci, E., and M. Kumar. 2010. "Fiscal Deficits, Public Debt, and Sovereign Bond Yields.” IMF Working Paper No. 10/184. Washington DC: International Monetary Fund.

Bindseil, U. 2004. Monetary Policy Implementation: Theory, Past, and Present. Oxford and New York: Oxford University Press.

Brown, R. L., J. Durbin, and J. M. Evans. 1975. "Techniques for Testing the Constancy of Regression Relationships over Time.” Journal of the Royal Statistical Society: Series B (Methodological) 37(2): 149-63.

Das, A., and T. Akram. 2020. "A Keynesian Analysis of Canadian Government Securities' Yields.” PSL Quarterly Review 73(294): 241-60.

Davidson, P. 2015. Post Keynesian Theory and Policy: A Realistic Analysis of the Market Oriented Capitalist Economy. Cheltenham, UK, and Northampton, MA: Edward Elgar.

Dickey, D. A., and W. A. Fuller. 1979. "Distribution of the Estimators for Autoregressive Time Series with a Unit Root." Journal of the American Statistical Association 74(366): 427-31.

- 1981. "Likelihood Ratio Statistics for Autoregressive Time Series with a Unit Root." Econometrica 49(4): 1057-72.

Fullwiler, S. T. 2016. "The Debt Ratio and Sustainable Macroeconomic Policy.” World Economic Review 7: 12-42.

—_. (2008) 2017. "Modern Central Bank Operations: The General Principles." In L.-P. Rochon and S. Rossi (eds.), Advances in Endogenous Money Analysis. Northampton, MA: Edward Elgar.

Goodheart, C.A.E. 1998. "Two Concepts of Money: Implications for the Analysis of Optimal Currency Areas." European Journal of Political Economy 14(3): 407-32.

Gruber, J. W., and S. B. Kamin. 2012. "Fiscal Positions and Government Bond Yields in OECD Countries.” Journal of Money, Credit, and Banking 44(8): 1563-87. 
Horioka, C. Y., T. Nomoto, and A. Terada-Hagiwara. 2014. "Why Has Japan's Massive Government Debt Not Wreaked Havoc (Yet)?" The Japanese Political Economy 40(2): 3-23.

Hoshi, T., and T. Ito. 2014. "Defying Gravity: Can Japanese Sovereign Debt Continue to Increase Without a Crisis?” Economic Policy 29(77): 5-44.

Jaramillo, L., and A. Weber. 2013. "Bond Yields in Emerging Economies: It Matters What State You Are In.” Emerging Markets Review 17: 169-85.

Johansen, S. 1995. Likelihood-Based Inference in Cointegrated Vector Autoregressive Models. Oxford: Oxford University Press.

Keynes, J. M. 1930. A Treatise on Money, Vol. II: The Applied Theory of Money. London: Macmillan.

. (1936) 2007. The General Theory of Employment, Interest, and Money. New York: Palgrave Macmillan.

Kregel, J. 2011. "Was Keynes' Monetary Policy À Outrance in the Treatise, A Forerunner of ZIRP and QE? Did He Change his Mind in the General Theory?" Levy Institute, Policy Note No. 2011/4. Annandale-on-Hudson, NY: Levy Economics Institute of Bard College.

Lerner, A.P. 1943. "Functional Finance and the Federal Debt." Social Research 10(1): 38-51. 1947. "Money as a Creature of the State." American Economic Review 37(2): 312 17.

Levrero, E. S., and M. Deleidi. 2019. "The Causal Relationship Between Short-and LongTerm Interest Rates: An Empirical Assessment of the United States.” MPRA Paper No. 93608. Munich: Munich University Library.

Macrobond. Various years. Macrobond subscription services. Available at: https://www.macrobond.com (accessed December 30, 2019).

Martinez, L. B., A. Tercenoa, and M. Teruelb. 2013. "Sovereign Bond Spreads Determinants in Latin American Countries: Before and During the XXI Financial Crisis." Emerging Markets Review 17: 60-75.

Malliaropulos, D., and P. Migiakis. 2018. "Quantitative Easing and Sovereign Bond Yields: A Global Perspective," Bank of Greece Working Paper, No. 253. Athens: Bank of Greece.

Mattos, O. B., F. Da Roz, F. O. Ultremare, and G. S. Mello. 2019. "Unconventional Monetary Policy and Negative Interest Rates: A Post-Keynesian Perspective on the Liquidity Trap and Euthanasia of the Rentier." Review of Keynesian Economics 7(2): 185-200. 
Min, H. G., D. H. Lee, C. Nam, M. C. Park, and S. H. Nam. 2003. "Determinants of Emerging- Market Bond Spreads: Cross-Country Evidence.” Global Finance Journal 14(3): 271-86.

Patra M. D., S. Pattanaik, J. John, and H. K. Behera. 2016. "Monetary Policy Transmission in India: Do Global Spillovers Matter?” RBI Occasional Papers 37(1\&2). Mumbai: Reserve Bank of India.

Pesaran, M. H., Y. Shin, and R. J. Smith 2001. "Bounds testing approaches to the analysis of level relationships.” Journal of Applied Econometrics 16(3): 289-326.

Phillips, P. C. B., and P. Perron. 1988. "Testing for a Unit Root in Time Series Regression." Biometrika 75(2): 335-46.

Poghosyan, T. 2014. "Long-Run and Short-Run Determinants of Sovereign Bond Yields in Advanced Economies." Economic Systems 38(1): 100-14.

Reinhart, C. M., and K. S. Rogoff. 2009. This Time is Different: Eight Centuries of Financial Folly. Princeton, NJ: Princeton University Press.

Riefler, W. W. 1930. Money Rates and Money Markets in the United States. New York and London: Harper \& Brothers.

Sau, L. 2018. "Coping with Deflation and the Liquidity Trap in the Eurozone: A Post Keynesian Approach.” Journal of Post Keynesian Economics 41(2): 210-35.

Simoski, S. 2019. "A Keynesian Exploration of the Determinants of Government Bond Yields for Brazil, Colombia, and Mexico." Master of Science thesis, Levy Economics Institute of Bard College. Annandale-on-Hudson, NY: Levy Economics Institute of Bard College. Available at: https://digitalcommons.bard.edu/levy_ms/16

Sims, C. A. 2013. "Paper Money.” American Economic Review 103(2): 563-84.

Tcherneva, P. R. 2011. “Bernanke's Paradox: Can He Reconcile His Position on the Federal Budget with His Recent Charge to Prevent Deflation?" Journal of Post Keynesian Economics 33(3): 411-34.

Tkačevs, O., and K. Vilerts. 2019. "The Impact of Government Borrowing Costs on Fiscal Discipline.” Kyklos 729(3): 446-71.

Turner, P. 2002. "Bond Markets in Emerging Economies: An Overview of Policy Issues." BIS Papers No. 11. Basel: Bank for International Settlements.

Wray, L. R. 2012. Modern Money Theory: A Primer on Macroeconomics for Sovereign Monetary Systems. New York: Palgrave Macmillan. 


\section{APPENDIX A: ADDITIONAL RESULTS FOR UNIT ROOT TESTS}

This appendix presents additional results for unit roots using Phillips-Perron tests.

Table A1. Phillips-Perron Unit Root Tests

\begin{tabular}{|l|l|l|l|l|}
\hline & \multicolumn{2}{l}{ Levels } & \multicolumn{2}{l|}{ First differences } \\
\hline Types of test & Variables & Test statistic & Variables & Test statistic \\
\hline No constant & CETES1M & 0.287 & $\Delta$ CETES1M & $-13.070^{* * *}$ \\
\hline Trend & CETES1M & -0.737 & $\Delta$ CETES1M & $-13.120^{* * *}$ \\
\hline No constant & CETES3M & 0.299 & $\Delta$ CETES3M & $-11.770^{* * *}$ \\
\hline Trend & CETES3M & -0.708 & $\Delta$ CETES3M & $-11.820^{* * *}$ \\
\hline No constant & CETES6M & 0.327 & $\Delta$ CETES6M & $-12.140^{* * *}$ \\
\hline Trend & CETES6M & -0.602 & $\Delta$ CETES6M & $-12.200^{* * *}$ \\
\hline No constant & CETES12M & 0.298 & $\Delta$ CETES12M & $-12.600^{* * *}$ \\
\hline Trend & CETES12M & -0.527 & $\Delta$ CETES12M & $-12.650^{* * *}$ \\
\hline No constant & MGB5Y & -0.025 & $\Delta$ MGB5Y & $-14.050^{* * *}$ \\
\hline Trend & MGB5Y & -1.085 & $\Delta$ MGB5Y & $-14.070^{* * *}$ \\
\hline No constant & MGB10Y & -0.191 & $\Delta$ MGB10Y & $-13.090^{* * *}$ \\
\hline Trend & MGB10Y & -1.393 & $\Delta$ MGB10Y & $-13.090^{* * *}$ \\
\hline No constant & MXN & 1.379 & $\Delta$ MXN & $-13.270^{* * *}$ \\
\hline Trend & MXN & -2.216 & $\Delta$ MXN & $-13.410^{* * *}$ \\
\hline No constant & TCPI & -0.433 & $\Delta$ TCPI & $-9.5770^{* * *}$ \\
\hline Trend & TCPI & -1.919 & $\Delta$ TCPI & $-9.5280^{* * *}$ \\
\hline No constant & CCPI & -0.480 & $\Delta$ CCPI & $-8.9940^{* * *}$ \\
\hline Trend & CCPI & -2.597 & $\Delta$ CCPI & $-8.9440 * * *$ \\
\hline No constant & IP & -2.939 & $\Delta$ IP & $-15.770^{* * *}$ \\
\hline Trend & IP & -3.066 & $\Delta$ IP & $-15.700^{* * *}$ \\
\hline & & & \\
\hline
\end{tabular}




\section{APPENDIX B: ADDITIONAL REGRESSION RESULTS USING DIFFERENT SHORT-TERM INTEREST RATES}

This appendix presents the additional regression results for different specifications of the models for MGB yields of different tenors with different short-term interest rates (CETES1M, CETES6M, and CETES12M). Here only the long-run and short-run coefficients for different models are provided. Additional details are available upon request.

Tables B1-B6 display results for MGB10Y yields. Tables B7-B12 display results for MGB5Y yields. Table B13-B18 display results for MBG3Y yields.

Tables for MGB10Y Yields

Table B1. Long-run Regression for MGB10Y, CETES6M, CCPI, and IP

\begin{tabular}{llllll}
\hline & \multicolumn{1}{c}{ Model 1 } & \multicolumn{1}{c}{ Model 2 } & \multicolumn{1}{c}{ Model 3 } & \multicolumn{1}{c}{ Model 4 } & \multicolumn{1}{c}{ Model 5 } \\
\cline { 2 - 6 } CETES6M & $0.608^{* * *}$ & $0.562^{* * * *}$ & $0.562^{* * *}$ & $0.410^{* * *}$ & $0.410^{* * *}$ \\
& $(0.0847)$ & $(0.142)$ & $(0.142)$ & $(0.113)$ & $(0.113)$ \\
CCPI & -0.106 & -0.119 & -0.119 & 0.0165 & 0.0165 \\
& $(0.1770)$ & $(0.3000)$ & $(0.3000)$ & $(0.2030)$ & $(0.2030)$ \\
IP & $-0.131^{*}$ & -0.234 & -0.234 & $-0.185^{*}$ & $-0.185^{*}$ \\
& $(0.0606)$ & $(0.1180)$ & $(0.1180)$ & $(0.0735)$ & $(0.0735)$ \\
Trend & & & & $-0.0100^{*}$ & \\
& & & & $(0.0039)$ & \\
Constant & & $4.645^{* * *}$ & & & \\
& & $(1.1910)$ & & & 177 \\
Adj. $R^{2}$ & 171 & 177 & 177 & 177 & 0.430 \\
\hline
\end{tabular}

Note 1: Standard errors in parentheses, ${ }^{*} p<0.05,{ }^{* *} p<0.01,{ }^{* * *} p<0.001$.

Note 2: Dependent variable is MGB10Y and independent variables are CETES6M, CCPI, and IP.

Note 3: Model 1: no intercept and no trend; Model 2: restricted intercept and no trend; Model 3: unrestricted and no trend; Model 4: unrestricted intercept and trend; and Model 5: unrestricted intercept and trend. 
Table B2. Short-run Regression for $\triangle \mathrm{MGB10Y,} \triangle \mathrm{CETES6M,} \Delta \mathrm{CCPI}$, and $\Delta \mathrm{IP}$

\begin{tabular}{|c|c|c|c|c|c|}
\hline & Model 1 & Model 2 & Model 3 & Model 4 & Model 5 \\
\hline \multicolumn{6}{|c|}{ Speed of adjustment } \\
\hline MGB10Y(-1) & $\begin{array}{l}-0.137^{* * *} \\
(0.0307)\end{array}$ & $\begin{array}{l}-0.0833^{* *} \\
(0.0279)\end{array}$ & $\begin{array}{l}-0.0833^{* *} \\
(0.0279)\end{array}$ & $\begin{array}{l}-0.125^{* * *} \\
(0.0339)\end{array}$ & $\begin{array}{l}-0.125^{* * *} \\
(0.0339)\end{array}$ \\
\hline \multicolumn{6}{|c|}{ Short-run regression } \\
\hline$\triangle$ CETES6M & $\begin{array}{l}0.832^{* * *} \\
(0.0880)\end{array}$ & $\begin{array}{l}0.851^{* * *} \\
(0.0825)\end{array}$ & $\begin{array}{l}0.851^{* * *} \\
(0.0825)\end{array}$ & $\begin{array}{l}0.879^{* * *} \\
(0.0827)\end{array}$ & $\begin{array}{l}0.879^{* * *} \\
(0.0827)\end{array}$ \\
\hline$\Delta$ CETES6M(-1) & $\begin{array}{l}-0.216^{*} \\
(0.0874)\end{array}$ & $\begin{array}{l}-0.296^{* * *} \\
(0.0818)\end{array}$ & $\begin{array}{l}-0.296^{* * *} \\
(0.0818)\end{array}$ & $\begin{array}{l}-0.232^{* *} \\
(0.0865)\end{array}$ & $\begin{array}{l}-0.232^{* *} \\
(0.0865)\end{array}$ \\
\hline$\Delta$ CETES6M(-2) & $\begin{array}{l}-0.104 \\
(0.0859)\end{array}$ & & & & \\
\hline$\Delta$ CETES6M(-3) & $\begin{array}{l}-0.146 \\
(0.0879)\end{array}$ & & & & \\
\hline$\Delta$ CETES6M(-4) & $\begin{array}{l}-0.216^{*} \\
(0.0870)\end{array}$ & & & & \\
\hline$\Delta \mathrm{IP}$ & $\begin{array}{l}0.023 \\
(0.0153)\end{array}$ & $\begin{array}{l}0.026 \\
(0.0156)\end{array}$ & $\begin{array}{l}0.026 \\
(0.0156)\end{array}$ & $\begin{array}{l}0.029 \\
(0.0155)\end{array}$ & $\begin{array}{l}0.029 \\
(0.0155)\end{array}$ \\
\hline Trend & & & & & $\begin{array}{l}-0.002^{*} \\
(0.0006)\end{array}$ \\
\hline Constant & $\begin{array}{l}0.571^{* * *} \\
(0.160)\end{array}$ & & $\begin{array}{l}0.387^{*} \\
(0.149)\end{array}$ & $\begin{array}{l}1.388^{* *} \\
(0.495)\end{array}$ & $\begin{array}{l}1.388^{* *} \\
(0.495)\end{array}$ \\
\hline$N$ & 171 & 177 & 177 & 177 & 177 \\
\hline Adj. $R^{2}$ & 0.437 & 0.418 & 0.418 & 0.430 & 0.430 \\
\hline
\end{tabular}

Note 1: Standard errors in parentheses, ${ }^{*} p<0.05,{ }^{* *} p<0.01,{ }^{* * *} p<0.001$.

Note 2: Dependent variable is MGB10Y and independent variables are CETES6M, CCPI, and IP.

Note 3: Model 1: no intercept and no trend; Model 2: restricted intercept and no trend; Model 3: unrestricted and no trend; Model 4: unrestricted intercept and trend; and Model 5: unrestricted intercept and trend. 
Table B3. Long-run Regression for MGB10Y, CETES12M, CCPI, and IP

\begin{tabular}{llllll}
\hline \multirow{2}{*}{ CETES12M } & \multicolumn{1}{c}{ Model 1 } & \multicolumn{1}{c}{ Model 2 } & \multicolumn{1}{c}{ Model 3 } & \multicolumn{1}{c}{ Model 4 } & \multicolumn{1}{c}{ Model 5 } \\
\cline { 2 - 6 } CCPI & $0.617^{* * *}$ & $0.600^{* * *}$ & $0.600^{* * *}$ & $0.431^{* * * *}$ & $0.431^{* * *}$ \\
& $(0.0924)$ & $(0.1390)$ & $(0.1390)$ & $(0.1090)$ & $(0.1090)$ \\
IP & -0.123 & -0.0839 & -0.0839 & 0.0396 & 0.0396 \\
& $(0.1880)$ & $(0.2860)$ & $(0.2860)$ & $(0.1930)$ & $(0.1930)$ \\
Trend & $-0.141^{*}$ & -0.200 & -0.200 & $-0.168^{*}$ & $-0.168^{*}$ \\
& $(0.0656)$ & $(0.1080)$ & $(0.1080)$ & $(0.0682)$ & $(0.0682)$ \\
Constant & & & & $-0.010^{* *}$ & \\
& & & & $(0.0036)$ & \\
\hline$N$ & & $4.187^{* * *}$ & & & \\
Adj. $R^{2}$ & 171 & $(1.1340)$ & & & 177 \\
\hline
\end{tabular}

Note 1: Standard errors in parentheses, ${ }^{*} p<0.05,{ }^{* *} p<0.01,{ }^{* * *} p<0.001$.

Note 2: Dependent variable is MGB10Y and independent variables are CETES12M, CCPI, and IP.

Note 3: Model 1: no intercept and no trend; Model 2: restricted intercept and no trend; Model 3: unrestricted and no trend; Model 4: unrestricted intercept and trend; and Model 5: unrestricted intercept and trend.

Table B4. Short-run Regression for MGB10Y, CETES12M, CCPI, and IP

\begin{tabular}{|c|c|c|c|c|c|}
\hline & Model 1 & Model 2 & Model 3 & Model 4 & Model 5 \\
\hline \multicolumn{6}{|l|}{ Speed of adjustment } \\
\hline MGB10Y(-1) & $\begin{array}{l}-0.125^{* * *} \\
(0.0308)\end{array}$ & $\begin{array}{l}-0.0831^{* *} \\
(0.0278)\end{array}$ & $\begin{array}{l}-0.0831^{* *} \\
(0.0278)\end{array}$ & $\begin{array}{l}-0.125^{* * *} \\
(0.0334)\end{array}$ & $\begin{array}{l}-0.125^{* * *} \\
(0.0334)\end{array}$ \\
\hline \multicolumn{6}{|c|}{ Short-run coefficient } \\
\hline$\triangle$ CETES12M & $\begin{array}{l}0.746^{* * *} \\
(0.0766)\end{array}$ & $\begin{array}{l}0.810^{* * *} \\
(0.0715)\end{array}$ & $\begin{array}{l}0.810^{* * *} \\
(0.0715)\end{array}$ & $\begin{array}{l}0.815^{* * *} \\
(0.0708)\end{array}$ & $\begin{array}{l}0.815^{* * *} \\
(0.0708)\end{array}$ \\
\hline$\Delta$ CETES12M(-1) & $\begin{array}{l}-0.185^{*} \\
(0.0743)\end{array}$ & $\begin{array}{l}-0.212^{* *} \\
(0.0696)\end{array}$ & $\begin{array}{l}-0.212^{* *} \\
(0.0696)\end{array}$ & $\begin{array}{l}-0.162^{*} \\
(0.0731)\end{array}$ & $\begin{array}{l}-0.162^{*} \\
(0.0731)\end{array}$ \\
\hline$\Delta$ CETES12M(-2) & $\begin{array}{l}-0.129 \\
(0.0734)\end{array}$ & $\begin{array}{l}-0.0959 \\
(0.0690)\end{array}$ & $\begin{array}{l}-0.0959 \\
(0.0690)\end{array}$ & & \\
\hline$\Delta$ CETES12M(-3) & $\begin{array}{l}-0.0568 \\
(0.0753)\end{array}$ & & & & \\
\hline$\Delta$ CETES12M(-4) & $\begin{array}{l}-0.137 \\
(0.0741)\end{array}$ & & & & \\
\hline$\Delta \mathrm{IP}$ & $\begin{array}{l}0.0282 \\
(0.0148)\end{array}$ & $\begin{array}{l}0.0279 \\
(0.0149)\end{array}$ & $\begin{array}{l}0.0279 \\
(0.0149)\end{array}$ & $\begin{array}{l}0.0317^{*} \\
(0.0148)\end{array}$ & $\begin{array}{l}0.0317^{*} \\
(0.0148)\end{array}$ \\
\hline Trend & & & & & $\begin{array}{l}-0.00121^{*} \\
(0.000555)\end{array}$ \\
\hline Constant & $\begin{array}{l}0.515^{* *} \\
(0.155)\end{array}$ & & $\begin{array}{l}0.348^{*} \\
(0.143)\end{array}$ & $\begin{array}{l}1.335^{* *} \\
(0.467)\end{array}$ & $\begin{array}{l}1.335^{* *} \\
(0.467)\end{array}$ \\
\hline$N$ & 171 & 177 & 177 & 177 & 177 \\
\hline Adj. $R^{2}$ & 0.468 & 0.471 & 0.471 & 0.480 & 0.480 \\
\hline
\end{tabular}

Note 1: Standard errors in parentheses, ${ }^{*} p<0.05,{ }^{* *} p<0.01,{ }^{* * *} p<0.001$.

Note 2: Dependent variable is MGB10Y and independent variables are CETES12M, CCPI, and IP.

Note 3: Model 1: no intercept and no trend; Model 2: restricted intercept and no trend; Model 3: unrestricted and no trend; Model 4: unrestricted intercept and trend; and Model 5: unrestricted intercept and trend. 
Table B5. Long-run Regression for MGB10Y, CETES1M, CCPI, and IP

\begin{tabular}{llllll}
\hline & \multicolumn{1}{c}{ Model 1 } & \multicolumn{1}{c}{ Model 2 } & \multicolumn{1}{c}{ Model 3 } & \multicolumn{1}{c}{ Model 4 } & \multicolumn{1}{c}{ Model 5 } \\
\cline { 2 - 6 } CETES1M & $0.538^{* * *}$ & $0.543^{* *}$ & $0.543^{* *}$ & $0.458^{* *}$ & $0.458^{* *}$ \\
& $(0.1030)$ & $(0.1710)$ & $(0.1710)$ & $(0.1730)$ & $(0.1730)$ \\
CCPI & -0.150 & -0.0971 & -0.0971 & -0.0275 & -0.0275 \\
& $(0.2200)$ & $(0.3610)$ & $(0.3610)$ & $(0.3100)$ & $(0.3100)$ \\
IP & -0.120 & -0.118 & -0.118 & -0.114 & -0.114 \\
& $(0.0714)$ & $(0.1170)$ & $(0.1170)$ & $(0.0976)$ & $(0.0976)$ \\
Trend & & & & -0.006 & \\
& & & & $(0.0062)$ & \\
Constant & & $4.742^{* *}$ & & & \\
& & $(1.4340)$ & & & 177 \\
Adj. $R^{2}$ & 171 & 177 & 177 & 177 & 0.131 \\
\hline
\end{tabular}

Note 1: Standard errors in parentheses, ${ }^{*} p<0.05,{ }^{* *} p<0.01,{ }^{* * *} p<0.001$.

Note 2: Dependent variable is MGB10Y and independent variables are CETES1M, CCPI, and IP.

Note 3: Model 1: no intercept and no trend; Model 2: restricted intercept and no trend; Model 3: unrestricted and no trend; Model 4: unrestricted intercept and trend; and Model 5: unrestricted intercept and trend.

Table B6. Short-run Regression for MGB10Y, CETES1M, CCPI, and IP

\begin{tabular}{|c|c|c|c|c|c|}
\hline & Model 1 & Model 2 & Model 3 & Model 4 & Model 5 \\
\hline \multicolumn{6}{|c|}{ Speed of adjustment } \\
\hline MGB10Y(-1) & $\begin{array}{l}-0.134^{* * *} \\
(0.0348)\end{array}$ & $\begin{array}{l}-0.0842^{* *} \\
(0.0318)\end{array}$ & $\begin{array}{l}-0.0842^{* *} \\
(0.0318)\end{array}$ & $\begin{array}{l}-0.101^{* *} \\
(0.0385)\end{array}$ & $\begin{array}{l}-0.101^{* *} \\
(0.0385)\end{array}$ \\
\hline \multicolumn{6}{|c|}{ Short-run coefficient } \\
\hline$\triangle$ CETES1M & $\begin{array}{l}0.381^{* * *} \\
(0.1010)\end{array}$ & $\begin{array}{l}0.439^{* * *} \\
(0.1030)\end{array}$ & $\begin{array}{l}0.439^{* * *} \\
(0.1030)\end{array}$ & $\begin{array}{l}0.458^{* * *} \\
(0.1060)\end{array}$ & $\begin{array}{l}0.458^{* * *} \\
(0.1060)\end{array}$ \\
\hline $\begin{array}{l}\Delta \text { CETES1M(- } \\
\text { 1) }\end{array}$ & $-0.283^{* *}$ & $-0.313^{* *}$ & $-0.313^{* *}$ & $-0.287^{* *}$ & $-0.287^{* *}$ \\
\hline & $(0.1010)$ & $(0.1020)$ & $(0.1020)$ & $(0.1080)$ & $(0.1080)$ \\
\hline Trend & & & & & $\begin{array}{l}-0.005 \\
(0.0007)\end{array}$ \\
\hline Constant & $\begin{array}{l}0.653^{* * *} \\
(0.1910)\end{array}$ & & $\begin{array}{l}0.399^{*} \\
(0.1780)\end{array}$ & $\begin{array}{l}0.846 \\
(0.6010)\end{array}$ & $\begin{array}{l}0.846 \\
(0.6010)\end{array}$ \\
\hline$N$ & 171 & 177 & 177 & 177 & 177 \\
\hline Adj. $R^{2}$ & 0.166 & 0.133 & 0.133 & 0.131 & 0.131 \\
\hline
\end{tabular}

Note 1: Standard errors in parentheses, ${ }^{*} p<0.05,{ }^{* *} p<0.01,{ }^{* * *} p<0.001$.

Note 2: Dependent variable is MGB10Y and independent variables are CETES1M, CCPI, and IP.

Note 3: Model 1: no intercept and no trend; Model 2: restricted intercept and no trend; Model 3: unrestricted and no trend; Model 4: unrestricted intercept and trend; and Model 5: unrestricted intercept and trend. 
Tables for MGB5Y yields

Table B7. Long-run Regression for MGB5Y and CETES6M, CCPI, and IP

\begin{tabular}{|c|c|c|c|c|c|}
\hline & Model 1 & Model 2 & Model 3 & Model 4 & Model 5 \\
\hline \multirow[t]{2}{*}{ CETES6M } & $0.717^{* *}$ & $0.691^{* * *}$ & $0.691^{* * *}$ & $0.655^{* * *}$ & $0.655^{* * *}$ \\
\hline & $(0.255)$ & $(0.070)$ & $(0.070)$ & $(0.086)$ & $(0.087)$ \\
\hline \multirow{2}{*}{ CCPI } & 0.628 & -0.110 & -0.110 & -0.084 & -0.084 \\
\hline & $(0.365)$ & $(0.146)$ & $(0.146)$ & $(0.143)$ & $(0.143)$ \\
\hline IP & -0.498 & $-0.140^{* *}$ & $-0.140^{* *}$ & $-0.139^{* *}$ & $-0.139^{* *}$ \\
\hline Trend & $(0.342)$ & $(0.052)$ & $(0.052)$ & $\begin{array}{l}(0.049) \\
-0.002 \\
(0.003)\end{array}$ & $(0.049)$ \\
\hline Constant & & $\begin{array}{l}3.252^{* * *} \\
(0.586)\end{array}$ & & & \\
\hline$N$ & 171 & 171 & 171 & 171 & 171 \\
\hline Adj. $R^{2}$ & 0.513 & 0.526 & 0.526 & 0.524 & 0.524 \\
\hline
\end{tabular}

Note 2: Dependent variable is MGB5Y and independent variables are CETES6M, CCPI, and IP.

Note 3: Model 1: no intercept and no trend; Model 2: restricted intercept and no trend; Model 3: unrestricted and no trend; Model 4: unrestricted intercept and trend; and Model 5: unrestricted intercept and trend. 
Table B8. Short-run Regression for MGB5Y and CETES6M, CCPI, and IP

\begin{tabular}{|c|c|c|c|c|c|}
\hline & Model 1 & Model 2 & Model 3 & Model 4 & Model 5 \\
\hline \multicolumn{6}{|c|}{ Speed of adjustment } \\
\hline MGB5Y(-1) & $\begin{array}{l}-0.0416 \\
(0.0220)\end{array}$ & $\begin{array}{l}-0.155^{* * *} \\
(0.0348)\end{array}$ & $\begin{array}{l}-0.155^{* * *} \\
(0.0348)\end{array}$ & $\begin{array}{l}-0.166^{* * *} \\
(0.0392)\end{array}$ & $\begin{array}{l}-0.166^{* * *} \\
(0.0392)\end{array}$ \\
\hline \multicolumn{6}{|c|}{ Short-run coefficient } \\
\hline$\Delta$ MGB5Y $(-1)$ & $\begin{array}{l}-0.207^{* * *} \\
(0.0562)\end{array}$ & $\begin{array}{l}-0.129 \\
(0.0758)\end{array}$ & $\begin{array}{l}-0.129 \\
(0.0758)\end{array}$ & $\begin{array}{l}-0.121 \\
(0.0769)\end{array}$ & $\begin{array}{l}-0.121 \\
(0.0769)\end{array}$ \\
\hline$\Delta$ MGB5Y(-2) & $\begin{array}{l}-0.155^{* *} \\
(0.0552)\end{array}$ & & & & \\
\hline$\Delta \mathrm{MGB} 5 \mathrm{Y}(-3)$ & $\begin{array}{l}-0.100 \\
(0.0578)\end{array}$ & & & & \\
\hline$\Delta \mathrm{MGB} 5 \mathrm{Y}(-4)$ & $\begin{array}{l}-0.193^{* * *} \\
(0.0562)\end{array}$ & & & & \\
\hline$\Delta \mathrm{MGB} 5 \mathrm{Y}(-5)$ & $\begin{array}{l}-0.0663 \\
(0.0549)\end{array}$ & & & & \\
\hline$\Delta$ MGB5Y(-6) & $\begin{array}{l}-0.152^{* *} \\
(0.0534)\end{array}$ & & & & \\
\hline$\Delta \mathrm{MGB} 5 \mathrm{Y}(-7)$ & $\begin{array}{l}-0.0883 \\
(0.0540)\end{array}$ & & & & \\
\hline$\Delta \mathrm{MGB} 5 \mathrm{Y}(-8)$ & $\begin{array}{l}-0.164^{* *} \\
(0.0545)\end{array}$ & & & & \\
\hline$\triangle$ CETES6M & $\begin{array}{l}1.028^{* * *} \\
(0.0830)\end{array}$ & $\begin{array}{l}0.964^{* * *} \\
(0.0861)\end{array}$ & $\begin{array}{l}0.964^{* * *} \\
(0.0861)\end{array}$ & $\begin{array}{l}0.968^{* * *} \\
(0.0865)\end{array}$ & $\begin{array}{l}0.968^{* * *} \\
(0.0865)\end{array}$ \\
\hline$\Delta$ CETES6M(-1) & & $\begin{array}{l}-0.0531 \\
(0.112)\end{array}$ & $\begin{array}{l}-0.0531 \\
(0.112)\end{array}$ & $\begin{array}{l}-0.0446 \\
(0.113)\end{array}$ & $\begin{array}{l}-0.0446 \\
(0.113)\end{array}$ \\
\hline$\Delta$ CETES6M(-2) & & $\begin{array}{l}-0.113 \\
(0.0838)\end{array}$ & $\begin{array}{l}-0.113 \\
(0.0838)\end{array}$ & $\begin{array}{l}-0.0984 \\
(0.0874)\end{array}$ & $\begin{array}{l}-0.0984 \\
(0.0874)\end{array}$ \\
\hline$\Delta$ CETES6M(-3) & & $\begin{array}{l}-0.149 \\
(0.0830)\end{array}$ & $\begin{array}{l}-0.149 \\
(0.0830)\end{array}$ & $\begin{array}{l}-0.137 \\
(0.0852)\end{array}$ & $\begin{array}{l}-0.137 \\
(0.0852)\end{array}$ \\
\hline$\Delta$ CETES6M(-4) & & $\begin{array}{l}-0.226^{* *} \\
(0.0819)\end{array}$ & $\begin{array}{l}-0.226^{* *} \\
(0.0819)\end{array}$ & $\begin{array}{l}-0.218^{* *} \\
(0.0830)\end{array}$ & $\begin{array}{l}-0.218^{* *} \\
(0.0830)\end{array}$ \\
\hline$\Delta \mathrm{IP}$ & & $\begin{array}{l}0.0220 \\
(0.0145)\end{array}$ & $\begin{array}{l}0.0220 \\
(0.0145)\end{array}$ & $\begin{array}{l}0.0233 \\
(0.0147)\end{array}$ & $\begin{array}{l}0.0233 \\
(0.0147)\end{array}$ \\
\hline Trend & & & & & $\begin{array}{l}-0.00035 \\
(0.00057)\end{array}$ \\
\hline Constant & & & $\begin{array}{l}0.504^{* * *} \\
(0.144)\end{array}$ & $\begin{array}{l}0.590^{* *} \\
(0.202)\end{array}$ & $\begin{array}{l}0.590^{* *} \\
(0.202)\end{array}$ \\
\hline$N$ & 171 & 171 & 171 & 171 & 171 \\
\hline Adj. $R^{2}$ & 0.513 & 0.526 & 0.526 & 0.524 & 0.524 \\
\hline
\end{tabular}

Note 1: Standard errors in parentheses, ${ }^{*} p<0.05,{ }^{* *} p<0.01,{ }^{* * *} p<0.001$.

Note 2: Dependent variable is MGB5Y and independent variables are CETES6M, CCPI, and IP.

Note 3: Model 1: no intercept and no trend; Model 2: restricted intercept and no trend; Model 3: unrestricted and no trend; Model 4: unrestricted intercept and trend; and Model 5: unrestricted intercept and trend. 
Table B9. Long-run Regression for MGB5Y with CETES12M, CCPI, and IP

\begin{tabular}{llllll}
\hline & \multicolumn{1}{c}{ Model 1 } & \multicolumn{1}{c}{ Model 2 } & \multicolumn{1}{c}{ Model 3 } & \multicolumn{1}{c}{ Model 4 } & \multicolumn{1}{c}{ Model 5 } \\
\cline { 2 - 6 } CETES12M & $0.729^{* * *}$ & $0.701^{* * *}$ & $0.701^{* * *}$ & $0.570^{* * *}$ & $0.570^{* * *}$ \\
& $(0.252)$ & $(0.093)$ & $(0.093)$ & $(0.073)$ & $(0.073)$ \\
CCPI & 0.586 & -0.0520 & -0.0520 & -0.0226 & -0.0226 \\
& $(0.363)$ & $(0.195)$ & $(0.195)$ & $(0.131)$ & $(0.131)$ \\
IP & -0.367 & $-0.213^{* *}$ & $-0.213^{* *}$ & $-0.153^{* *}$ & $-0.153^{* *}$ \\
& $(0.275)$ & $(0.085)$ & $(0.085)$ & $(0.047)$ & $(0.047)$ \\
Trend & & & & $-0.007^{*}$ & \\
& & & & $(0.003)$ & \\
Constant & & $2.921^{* * *}$ & & & \\
& & $(0.782)$ & & & 171 \\
Adj. $R^{2}$ & 171 & 171 & 171 & 171 & 0.561 \\
\hline
\end{tabular}

Note 1: Standard errors in parentheses, ${ }^{*} p<0.05,{ }^{* *} p<0.01,{ }^{* * *} p<0.001$.

Note 2: Dependent variable is MGB5Y and independent variables are CETES12M, CCPI, and IP.

Note 3: Model 1: no intercept and no trend; Model 2: restricted intercept and no trend; Model 3: unrestricted and no trend; Model 4: unrestricted intercept and trend; and Model 5: unrestricted intercept and trend. 
Table B10. Short-run Regression for MGB5Y, with CETES12M, CCPI, and IP

\begin{tabular}{|c|c|c|c|c|c|}
\hline & Model 1 & Model 2 & Model 3 & Model 4 & Model 5 \\
\hline $\begin{array}{l}\text { Speed of adjustment } \\
\text { MGB5Y(-1) }\end{array}$ & $\begin{array}{l}-0.041 \\
(0.0226)\end{array}$ & $\begin{array}{l}-0.112^{* *} \\
(0.0352)\end{array}$ & $\begin{array}{l}-0.112^{* *} \\
(0.0352)\end{array}$ & $\begin{array}{l}-0.171^{* * *} \\
(0.0391)\end{array}$ & $\begin{array}{l}-0.171^{* * *} \\
(0.0391)\end{array}$ \\
\hline Short-run coefficient & & & & & \\
\hline$\Delta$ MGB5Y(-1) & $\begin{array}{l}-0.178^{* * *} \\
(0.0526)\end{array}$ & $\begin{array}{l}-0.148^{* *} \\
(0.0529)\end{array}$ & $\begin{array}{l}-0.148^{* *} \\
(0.0529)\end{array}$ & $\begin{array}{l}-0.0959 \\
(0.0544)\end{array}$ & $\begin{array}{l}-0.0959 \\
(0.0544)\end{array}$ \\
\hline$\triangle \mathrm{MGB} 5 \mathrm{Y}(-2)$ & $\begin{array}{l}-0.132^{*} \\
(0.0521)\end{array}$ & $\begin{array}{l}-0.120^{*} \\
(0.0520)\end{array}$ & $\begin{array}{l}-0.120^{*} \\
(0.0520)\end{array}$ & & \\
\hline$\triangle \mathrm{MGB} 5 \mathrm{Y}(-3)$ & $\begin{array}{l}-0.039 \\
(0.0544)\end{array}$ & $\begin{array}{l}-0.041 \\
(0.0537)\end{array}$ & $\begin{array}{l}-0.041 \\
(0.0537)\end{array}$ & & \\
\hline$\triangle \mathrm{MGB} 5 \mathrm{Y}(-4)$ & $\begin{array}{l}-0.146^{* *} \\
(0.0530)\end{array}$ & $\begin{array}{l}-0.143^{* *} \\
(0.0523)\end{array}$ & $\begin{array}{l}-0.143^{* *} \\
(0.0523)\end{array}$ & & \\
\hline$\Delta$ MGB5Y $(-5)$ & $\begin{array}{l}-0.089 \\
(0.0528)\end{array}$ & $\begin{array}{l}-0.069 \\
(0.0522)\end{array}$ & $\begin{array}{l}-0.069 \\
(0.0522)\end{array}$ & & \\
\hline$\triangle \mathrm{MGB} 5 \mathrm{Y}(-6)$ & $\begin{array}{l}-0.075 \\
(0.0514)\end{array}$ & $\begin{array}{l}-0.069 \\
(0.0508)\end{array}$ & $\begin{array}{l}-0.069 \\
(0.0508)\end{array}$ & & \\
\hline$\triangle \mathrm{MGB} 5 \mathrm{Y}(-7)$ & $\begin{array}{l}-0.037 \\
(0.0522)\end{array}$ & $\begin{array}{l}-0.036 \\
(0.0511)\end{array}$ & $\begin{array}{l}-0.036 \\
(0.0511)\end{array}$ & & \\
\hline$\Delta \mathrm{MGB} 5 \mathrm{Y}(-8)$ & $\begin{array}{l}-0.141^{* *} \\
(0.0516)\end{array}$ & $\begin{array}{l}-0.117^{*} \\
(0.0511)\end{array}$ & $\begin{array}{l}-0.117^{*} \\
(0.0511)\end{array}$ & & \\
\hline$\triangle$ CETES12M & $\begin{array}{l}0.955^{* * *} \\
(0.0703)\end{array}$ & $\begin{array}{l}0.883^{* * *} \\
(0.0734)\end{array}$ & $\begin{array}{l}0.883^{* * *} \\
(0.0734)\end{array}$ & $\begin{array}{l}0.858^{* * *} \\
(0.0735)\end{array}$ & $\begin{array}{l}0.858^{* * *} \\
(0.0735)\end{array}$ \\
\hline$\Delta \mathrm{IP}$ & $\begin{array}{l}0.024 \\
(0.0144)\end{array}$ & $\begin{array}{l}0.029^{*} \\
(0.0140)\end{array}$ & $\begin{array}{l}0.029^{*} \\
(0.0140)\end{array}$ & $\begin{array}{l}0.032^{*} \\
(0.0138)\end{array}$ & $\begin{array}{l}0.032^{*} \\
(0.0138)\end{array}$ \\
\hline$\Delta \mathrm{IP}(-1)$ & $\begin{array}{l}-0.015 \\
(0.0144)\end{array}$ & & & & \\
\hline$\Delta \mathrm{IP}(-2)$ & $\begin{array}{l}-0.027 \\
(0.0143)\end{array}$ & & & & \\
\hline Trend & & & & & $\begin{array}{l}-0.001^{*} \\
(0.0005)\end{array}$ \\
\hline Constant & & & $\begin{array}{l}0.328^{*} \\
(0.1400)\end{array}$ & $\begin{array}{l}0.713^{* * *} \\
(0.1800)\end{array}$ & $\begin{array}{l}0.713^{* * *} \\
(0.1800)\end{array}$ \\
\hline$N$ & 171 & 171 & 171 & 171 & 171 \\
\hline Adj. $R^{2}$ & 0.568 & 0.577 & 0.577 & 0.561 & 0.561 \\
\hline
\end{tabular}

Note 1: Standard errors in parentheses, ${ }^{*} p<0.05,{ }^{* *} p<0.01,{ }^{* * *} p<0.001$.

Note 2: Dependent variable is MGB5Y and independent variables are CETES12M, CCPI, and IP.

Note 3: Model 1: no intercept and no trend; Model 2: restricted intercept and no trend; Model 3: unrestricted and no trend; Model 4: unrestricted intercept and trend; and Model 5: unrestricted intercept and trend. 
Table B11. Long-run Regression for MGB5Y with CETES1M, CCPI, and IP

\begin{tabular}{llllll}
\hline & \multicolumn{1}{c}{ Model 1 } & \multicolumn{1}{c}{ Model 2 } & \multicolumn{1}{c}{ Model 3 } & \multicolumn{1}{c}{ Model 4 } & \multicolumn{1}{c}{ Model 5 } \\
\cline { 2 - 6 } CETES1M & $0.674^{* *}$ & $0.629^{* * *}$ & $0.629^{* * *}$ & $0.615^{* * *}$ & $0.615^{* * *}$ \\
& $(0.2520)$ & $(0.0823)$ & $(0.0823)$ & $(0.0994)$ & $(0.0994)$ \\
CCPI & 0.653 & -0.147 & -0.147 & -0.135 & -0.135 \\
& $(0.3450)$ & $(0.1750)$ & $(0.1750)$ & $(0.1790)$ & $(0.1790)$ \\
IP & -0.0857 & -0.106 & -0.106 & -0.106 & -0.106 \\
& $(0.1660)$ & $(0.0554)$ & $(0.0554)$ & $(0.0542)$ & $(0.0542)$ \\
Trend & & & & -0.0009 & \\
& & & & $(0.0039)$ & \\
Constant & & $3.882^{* * *}$ & & & \\
& & $(0.695)$ & & & \\
\hline$N$ & 171 & 171 & 171 & 171 & 171 \\
Adj. $R^{2}$ & 0.111 & 0.177 & 0.177 & 0.173 & 0.173 \\
\hline
\end{tabular}

Note 1: Standard errors in parentheses, ${ }^{*} p<0.05,{ }^{* *} p<0.01,{ }^{* * *} p<0.001$.

Note 2: Dependent variable is MGB5Y and independent variables are CETES1M, CCPI, and IP.

Note 3: Model 1: no intercept and no trend; Model 2: restricted intercept and no trend; Model 3: unrestricted and no trend; Model 4: unrestricted intercept and trend; and Model 5: unrestricted intercept and trend.

Table B12. Short-run Regression for MGB5Y, CETES1M, CCPI, and IP

\begin{tabular}{llllll}
\hline & \multicolumn{1}{c}{ Model 1 } & Model 2 & Model 3 & Model 4 & Model 5 \\
\cline { 2 - 6 } Speed of adjustment & & & & & \\
MGB5Y(-1) & $-0.057^{*}$ & $-0.171^{* * *}$ & $-0.171^{* * *}$ & $-0.175^{* * *}$ & $-0.175^{* * *}$ \\
& $(0.0272)$ & $(0.0408)$ & $(0.0408)$ & $(0.0446)$ & $(0.0446)$ \\
Short-run coefficients & & & & & \\
$\Delta$ CETES1M & $0.449^{* * *}$ & $0.433^{* * *}$ & $0.433^{* * *}$ & $0.439^{* * *}$ & $0.439^{* * *}$ \\
& $(0.1060)$ & $(0.1030)$ & $(0.1030)$ & $(0.1060)$ & $(0.1060)$ \\
$\Delta$ CETES1M(-1) & $-0.236^{*}$ & -0.196 & -0.196 & -0.188 & -0.188 \\
& $(0.1050)$ & $(0.1020)$ & $(0.1020)$ & $(0.1080)$ & $(0.1080)$ \\
Trend & & & & & -0.0002 \\
& & & & & $(0.0007)$ \\
Constant & & & $0.664^{* * *}$ & $0.700^{* *}$ & $0.700^{* *}$ \\
& & & $(0.1820)$ & $(0.2380)$ & $(0.2380)$ \\
\hline$N$ & 171 & 171 & 171 & 171 & 171 \\
Adj. $R^{2}$ & 0.111 & 0.177 & 0.177 & 0.173 & 0.173 \\
\hline
\end{tabular}

Note 1: Standard errors in parentheses, ${ }^{*} p<0.05,{ }^{* *} p<0.01,{ }^{* * *} p<0.001$.

Note 2: Dependent variable is MGB5Y and independent variables are CETES1M, CCPI, and IP.

Note 3: Model 1: no intercept and no trend; Model 2: restricted intercept and no trend; Model 3: unrestricted and no trend; Model 4: unrestricted intercept and trend; and Model 5: unrestricted intercept and trend. 
Tables for MGB3Y Yields

Table B13. Long-run Regression for MGB3Y, CETES6M, CCPI, and IP

\begin{tabular}{llllll}
\hline \multirow{2}{*}{ CETES6M } & \multicolumn{1}{c}{ Model 1 } & \multicolumn{1}{c}{ Model 2 } & \multicolumn{1}{c}{ Model 3 } & \multicolumn{1}{c}{ Model 4 } & \multicolumn{1}{c}{ Model 5 } \\
\cline { 2 - 6 } & 0.708 & $0.772^{* * *}$ & $0.772^{* * *}$ & $0.755^{* * *}$ & $0.755^{* * *}$ \\
CCPI & $(0.551)$ & $(0.083)$ & $(0.083)$ & $(0.084)$ & $(0.084)$ \\
& 0.682 & -0.098 & -0.098 & -0.106 & -0.106 \\
IP & $(0.779)$ & $(0.107)$ & $(0.107)$ & $(0.105)$ & $(0.105)$ \\
& -0.453 & 0.014 & 0.014 & 0.038 & 0.038 \\
Trend & $(0.652)$ & $(0.050)$ & $(0.050)$ & $(0.055)$ & $(0.055)$ \\
& & & & 0.004 & \\
Constant & & & & $(0.004)$ & \\
& & $2.084^{* * *}$ & & & \\
\hline$N$ & 102 & 102 & 102 & 102 & 102 \\
Adj. $R^{2}$ & 0.554 & 0.555 & 0.555 & 0.554 & 0.554 \\
\hline
\end{tabular}

Note 1: Standard errors in parentheses, ${ }^{*} p<0.05,{ }^{* *} p<0.01,{ }^{* * *} p<0.001$.

Note 2: Dependent variable is MGB3Y and independent variables are CETES6M, CCPI, and IP.

Note 3: Model 1: no intercept and no trend; Model 2: restricted intercept and no trend; Model 3: unrestricted and no trend; Model 4: unrestricted intercept and trend; and Model 5: unrestricted intercept and trend. 
Table B14. Short-run Regression for MGB3Y, CETES6M, CCPI, and IP

\begin{tabular}{|c|c|c|c|c|c|}
\hline & Model 1 & Model 2 & Model 3 & Model 4 & Model 5 \\
\hline \multicolumn{6}{|c|}{ Speed of adjustment } \\
\hline MGB3Y(-1) & $\begin{array}{l}-0.037 \\
(0.0321)\end{array}$ & $\begin{array}{l}-0.240^{* *} \\
(0.0748)\end{array}$ & $\begin{array}{l}-0.240^{* *} \\
(0.0748)\end{array}$ & $\begin{array}{l}-0.245^{* *} \\
(0.0750)\end{array}$ & $\begin{array}{l}-0.245^{* *} \\
(0.0750)\end{array}$ \\
\hline \multicolumn{6}{|c|}{ Short-run coefficient } \\
\hline$\Delta \mathrm{MGB} 3 \mathrm{Y}(-1)$ & $\begin{array}{l}-0.276^{*} \\
(0.1120)\end{array}$ & $\begin{array}{l}-0.110 \\
(0.1200)\end{array}$ & $\begin{array}{l}-0.110 \\
(0.1200)\end{array}$ & $\begin{array}{l}-0.105 \\
(0.1200)\end{array}$ & $\begin{array}{l}-0.105 \\
(0.1200)\end{array}$ \\
\hline$\Delta \mathrm{MGB} 3 \mathrm{Y}(-2)$ & $\begin{array}{l}0.053 \\
(0.1140)\end{array}$ & $\begin{array}{l}0.266^{*} \\
(0.1160)\end{array}$ & $\begin{array}{l}0.266^{*} \\
(0.1160)\end{array}$ & $\begin{array}{l}0.270^{*} \\
(0.1160)\end{array}$ & $\begin{array}{l}0.270^{*} \\
(0.1160)\end{array}$ \\
\hline$\Delta \mathrm{MGB} 3 \mathrm{Y}(-3)$ & $\begin{array}{l}-0.008 \\
(0.0820)\end{array}$ & $\begin{array}{l}0.283^{*} \\
(0.1130)\end{array}$ & $\begin{array}{l}0.283^{*} \\
(0.1130)\end{array}$ & $\begin{array}{l}0.289^{*} \\
(0.1130)\end{array}$ & $\begin{array}{l}0.289^{*} \\
(0.1130)\end{array}$ \\
\hline$\triangle \mathrm{MGB} 3 \mathrm{Y}(-4)$ & $\begin{array}{l}-0.198^{*} \\
(0.0792)\end{array}$ & & & & \\
\hline$\Delta \mathrm{MGB} 3 \mathrm{Y}(-5)$ & $\begin{array}{l}0.055 \\
(0.0787)\end{array}$ & & & & \\
\hline$\triangle \mathrm{MGB} 3 \mathrm{Y}(-6)$ & $\begin{array}{l}-0.148 \\
(0.0785)\end{array}$ & & & & \\
\hline$\Delta \mathrm{MGB} 3 \mathrm{Y}(-7)$ & $\begin{array}{l}-0.177^{*} \\
(0.0797)\end{array}$ & & & & \\
\hline$\triangle \mathrm{MGB} 3 \mathrm{Y}(-8)$ & $\begin{array}{l}-0.117 \\
(0.0829)\end{array}$ & & & & \\
\hline$\triangle$ CETES6M & $\begin{array}{l}1.046^{* * *} \\
(0.1110)\end{array}$ & $\begin{array}{l}0.912^{* * *} \\
(0.1210)\end{array}$ & $\begin{array}{l}0.912^{* * *} \\
(0.1210)\end{array}$ & $\begin{array}{l}0.890^{* * *} \\
(0.1230)\end{array}$ & $\begin{array}{l}0.890^{* * *} \\
(0.1230)\end{array}$ \\
\hline$\Delta$ CETES6M(-1) & $\begin{array}{l}0.192 \\
(0.1600)\end{array}$ & $\begin{array}{l}0.005 \\
(0.1640)\end{array}$ & $\begin{array}{l}0.005 \\
(0.1640)\end{array}$ & $\begin{array}{l}-0.018 \\
(0.1650)\end{array}$ & $\begin{array}{l}-0.018 \\
(0.1650)\end{array}$ \\
\hline$\triangle$ CETES6M(-2) & $\begin{array}{l}-0.250 \\
(0.1540)\end{array}$ & $\begin{array}{l}-0.436^{* *} \\
(0.1520)\end{array}$ & $\begin{array}{l}-0.436^{* *} \\
(0.1520)\end{array}$ & $\begin{array}{l}-0.453^{* *} \\
(0.1530)\end{array}$ & $\begin{array}{l}-0.453^{* *} \\
(0.1530)\end{array}$ \\
\hline$\Delta$ CETES6M(-3) & & $\begin{array}{l}-0.314^{*} \\
(0.1510)\end{array}$ & $\begin{array}{l}-0.314^{*} \\
(0.1510)\end{array}$ & $\begin{array}{l}-0.331^{*} \\
(0.1520)\end{array}$ & $\begin{array}{l}-0.331^{*} \\
(0.1520)\end{array}$ \\
\hline$\Delta$ CETES6M(-4) & & $\begin{array}{l}-0.103 \\
(0.1140)\end{array}$ & $\begin{array}{l}-0.103 \\
(0.1140)\end{array}$ & $\begin{array}{l}-0.113 \\
(0.1150)\end{array}$ & $\begin{array}{l}-0.113 \\
(0.1150)\end{array}$ \\
\hline$\triangle$ CETES6M(-5) & & $\begin{array}{l}0.204 \\
(0.1130)\end{array}$ & $\begin{array}{l}0.204 \\
(0.1130)\end{array}$ & $\begin{array}{l}0.196 \\
(0.1130)\end{array}$ & $\begin{array}{l}0.196 \\
(0.1130)\end{array}$ \\
\hline Trend & & & & & $\begin{array}{l}0.001 \\
(0.0010)\end{array}$ \\
\hline Constant & & & $\begin{array}{l}0.500^{* *} \\
(0.1850)\end{array}$ & $\begin{array}{l}0.416^{*} \\
(0.2050)\end{array}$ & $\begin{array}{l}0.416^{*} \\
(0.2050)\end{array}$ \\
\hline$N$ & 102 & 102 & 102 & 102 & 102 \\
\hline Adj. $R^{2}$ & 0.554 & 0.555 & 0.555 & 0.554 & 0.554 \\
\hline
\end{tabular}

Note 1: Standard errors in parentheses, ${ }^{*} p<0.05,{ }^{* *} p<0.01,{ }^{* * *} p<0.001$.

Note 2: Dependent variable is MGB3Y and independent variables are CETES6M, CCPI, and IP.

Note 3: Model 1: no intercept and no trend; Model 2: restricted intercept and no trend; Model 3: unrestricted and no trend; Model 4: unrestricted intercept and trend; and Model 5: unrestricted intercept and trend. 
Table B15. Long-run Regression for MGB3Y, CETES12M, CCPI, and IP

\begin{tabular}{|c|c|c|c|c|c|}
\hline & Model 1 & Model 2 & Model 3 & Model 4 & Model 5 \\
\hline CETES12M & $\begin{array}{l}0.890^{*} \\
(0.4030)\end{array}$ & $\begin{array}{l}0.790^{* * * *} \\
(0.0855)\end{array}$ & $\begin{array}{l}0.790^{* * *} \\
(0.0855)\end{array}$ & $\begin{array}{l}0.811^{* * * *} \\
(0.0857)\end{array}$ & $\begin{array}{l}0.811^{* * * *} \\
(0.0857)\end{array}$ \\
\hline CCPI & $\begin{array}{l}0.358 \\
(0.5210)\end{array}$ & $\begin{array}{l}-0.099 \\
(0.1210)\end{array}$ & $\begin{array}{l}-0.099 \\
(0.1210)\end{array}$ & $\begin{array}{l}-0.144 \\
(0.1160)\end{array}$ & $\begin{array}{l}-0.144 \\
(0.1160)\end{array}$ \\
\hline IP & $\begin{array}{l}-0.259 \\
(0.4030)\end{array}$ & $\begin{array}{l}0.008 \\
(0.0491)\end{array}$ & $\begin{array}{l}0.008 \\
(0.0491)\end{array}$ & $\begin{array}{l}0.027 \\
(0.0518)\end{array}$ & $\begin{array}{l}0.027 \\
(0.0518)\end{array}$ \\
\hline Trend & & & & $\begin{array}{l}0.003 \\
(0.0037)\end{array}$ & \\
\hline Constant & & $\begin{array}{l}1.909^{* * *} \\
(0.3420)\end{array}$ & & & \\
\hline$N$ & 102 & 102 & 102 & 102 & 102 \\
\hline Adj. $R^{2}$ & 0.676 & 0.684 & 0.684 & 0.685 & 0.685 \\
\hline
\end{tabular}

Note 2: Dependent variable is MGB3Y and independent variables are CETES12M, CCPI, and IP.

Note 3: Model 1: no intercept and no trend; Model 2: restricted intercept and no trend; Model 3: unrestricted and no trend; Model 4: unrestricted intercept and trend; and Model 5: unrestricted intercept and trend. 
Table B16. Short-run Regression for MGB3Y, CETES12M, CCPI, and IP

\begin{tabular}{|c|c|c|c|c|c|}
\hline & Model 1 & Model 2 & Model 3 & Model 4 & Model 5 \\
\hline \multicolumn{6}{|l|}{ Speed of adjustment } \\
\hline MGB3Y(-1) & $\begin{array}{l}-0.040 \\
(0.0303)\end{array}$ & $\begin{array}{l}-0.202^{* *} \\
(0.0693)\end{array}$ & $\begin{array}{l}-0.202^{* *} \\
(0.0693)\end{array}$ & $\begin{array}{l}-0.217^{* *} \\
(0.0698)\end{array}$ & $\begin{array}{l}-0.217^{* *} \\
(0.0698)\end{array}$ \\
\hline \multicolumn{6}{|c|}{ Short-run coefficient } \\
\hline$\Delta \mathrm{MGB} 3 \mathrm{Y}(-1)$ & $\begin{array}{l}-0.254^{*} \\
(0.1050)\end{array}$ & $\begin{array}{l}-0.098 \\
(0.1100)\end{array}$ & $\begin{array}{l}-0.098 \\
(0.1100)\end{array}$ & $\begin{array}{l}-0.128 \\
(0.1140)\end{array}$ & $\begin{array}{l}-0.128 \\
(0.1140)\end{array}$ \\
\hline$\Delta \mathrm{MGB} 3 \mathrm{Y}(-2)$ & $\begin{array}{l}0.116 \\
(0.1050)\end{array}$ & $\begin{array}{l}0.285^{* *} \\
(0.1070)\end{array}$ & $\begin{array}{l}0.285^{* *} \\
(0.1070)\end{array}$ & $\begin{array}{l}0.303^{* *} \\
(0.1070)\end{array}$ & $\begin{array}{l}0.303^{* *} \\
(0.1070)\end{array}$ \\
\hline$\Delta \mathrm{MGB} 3 \mathrm{Y}(-3)$ & $\begin{array}{l}0.009 \\
(0.0717)\end{array}$ & $\begin{array}{l}0.124 \\
(0.0685)\end{array}$ & $\begin{array}{l}0.124 \\
(0.0685)\end{array}$ & $\begin{array}{l}0.238^{*} \\
(0.1060)\end{array}$ & $\begin{array}{l}0.238^{*} \\
(0.1060)\end{array}$ \\
\hline$\triangle \mathrm{MGB} 3 \mathrm{Y}(-4)$ & $\begin{array}{l}-0.072 \\
(0.0665)\end{array}$ & & & & \\
\hline$\Delta \mathrm{MGB} 3 \mathrm{Y}(-5)$ & $\begin{array}{l}0.008 \\
(0.0665)\end{array}$ & & & & \\
\hline$\Delta \mathrm{MGB} 3 \mathrm{Y}(-6)$ & $\begin{array}{l}-0.134^{*} \\
(0.0660)\end{array}$ & & & & \\
\hline$\Delta \mathrm{MGB} 3 \mathrm{Y}(-7)$ & $\begin{array}{l}-0.140^{*} \\
(0.0658)\end{array}$ & & & & \\
\hline$\triangle$ CETES12M & $\begin{array}{l}1.099^{* * *} \\
(0.0916)\end{array}$ & $\begin{array}{l}0.962^{* * *} \\
(0.1050)\end{array}$ & $\begin{array}{l}0.962^{* * *} \\
(0.1050)\end{array}$ & $\begin{array}{l}0.933^{* * *} \\
(0.1080)\end{array}$ & $\begin{array}{l}0.933^{* * *} \\
(0.1080)\end{array}$ \\
\hline$\Delta$ CETES12M(-1) & $\begin{array}{l}0.188 \\
(0.1440)\end{array}$ & $\begin{array}{l}0.007 \\
(0.1480)\end{array}$ & $\begin{array}{l}0.007 \\
(0.1480)\end{array}$ & $\begin{array}{l}0.029 \\
(0.1550)\end{array}$ & $\begin{array}{l}0.029 \\
(0.1550)\end{array}$ \\
\hline$\Delta$ CETES12M(-2) & $\begin{array}{l}-0.428^{* *} \\
(0.1370)\end{array}$ & $\begin{array}{l}-0.568^{* * *} \\
(0.1420)\end{array}$ & $\begin{array}{l}-0.568^{* * *} \\
(0.1420)\end{array}$ & $\begin{array}{l}-0.616^{* * *} \\
(0.1460)\end{array}$ & $\begin{array}{l}-0.616^{* * *} \\
(0.1460)\end{array}$ \\
\hline$\Delta$ CETES12M(-3) & & & & $\begin{array}{l}-0.205 \\
(0.1460)\end{array}$ & $\begin{array}{l}-0.205 \\
(0.1460)\end{array}$ \\
\hline$\triangle \mathrm{CCPI}$ & & $\begin{array}{l}-0.048 \\
(0.0495)\end{array}$ & $\begin{array}{l}-0.048 \\
(0.0495)\end{array}$ & $\begin{array}{l}-0.050 \\
(0.0495)\end{array}$ & $\begin{array}{l}-0.050 \\
(0.0495)\end{array}$ \\
\hline$\Delta \mathrm{CCPI}(-1)$ & & $\begin{array}{l}-0.034 \\
(0.0523)\end{array}$ & $\begin{array}{l}-0.034 \\
(0.0523)\end{array}$ & $\begin{array}{l}-0.018 \\
(0.0534)\end{array}$ & $\begin{array}{l}-0.018 \\
(0.0534)\end{array}$ \\
\hline$\Delta \mathrm{CCPI}(-2)$ & & $\begin{array}{l}0.098 \\
(0.0512)\end{array}$ & $\begin{array}{l}0.098 \\
(0.0512)\end{array}$ & $\begin{array}{l}0.102^{*} \\
(0.0513)\end{array}$ & $\begin{array}{l}0.102^{*} \\
(0.0513)\end{array}$ \\
\hline Trend & & & & & $\begin{array}{l}0.001 \\
(0.0008)\end{array}$ \\
\hline Constant & & & $\begin{array}{l}0.386^{*} \\
(0.156) \\
\end{array}$ & $\begin{array}{l}0.350^{*} \\
(0.171) \\
\end{array}$ & $\begin{array}{l}0.350^{*} \\
(0.171) \\
\end{array}$ \\
\hline$N$ & 102 & 102 & 102 & 102 & 102 \\
\hline Adj. $R^{2}$ & 0.676 & 0.684 & 0.684 & 0.685 & 0.685 \\
\hline
\end{tabular}

Note 1: Standard errors in parentheses, ${ }^{*} p<0.05,{ }^{* *} p<0.01,{ }^{* * *} p<0.001$.

Note 2: Dependent variable is MGB3Y and independent variables are CETES12M, CCPI, and IP.

Note 3: Model 1: no intercept and no trend; Model 2: restricted intercept and no trend; Model 3: unrestricted and no trend; Model 4: unrestricted intercept and trend; and Model 5: unrestricted intercept and trend. 
Table B17. Long-run Regression for MGB3Y, CETES1M, CCPI, and IP

\begin{tabular}{llllll}
\hline & \multicolumn{1}{c}{ Model 1 } & \multicolumn{1}{c}{ Model 2 } & \multicolumn{1}{c}{ Model 3 } & \multicolumn{1}{c}{ Model 4 } & \multicolumn{1}{c}{ Model 5 } \\
\cline { 2 - 6 } CETES1M & 0.989 & $0.832^{* * *}$ & $0.832^{* * *}$ & 0.600 & 0.600 \\
& $(1.0230)$ & $(0.1190)$ & $(0.1190)$ & $(0.4710)$ & $(0.4710)$ \\
CCPI & 0.732 & -0.171 & -0.171 & 0.114 & 0.114 \\
& $(1.3760)$ & $(0.1630)$ & $(0.1630)$ & $(0.6570)$ & $(0.6570)$ \\
IP & -0.939 & -0.040 & -0.040 & -0.146 & -0.146 \\
& $(1.8310)$ & $(0.0732)$ & $(0.0732)$ & $(0.3980)$ & $(0.3980)$ \\
Trend & & & & 0.039 & \\
& & & & $(0.0644)$ & \\
Constant & & $2.419^{* * *}$ & & & \\
& & $(0.506)$ & & & \\
\hline$N$ & 102 & 102 & 102 & 102 & 102 \\
Adj. $R^{2}$ & 0.194 & 0.141 & 0.141 & 0.216 & 0.216 \\
\hline
\end{tabular}

Note 1: Standard errors in parentheses, ${ }^{*} p<0.05,{ }^{* *} p<0.01,{ }^{* * *} p<0.001$.

Note 2: Dependent variable is MGB3Y and independent variables are CETES1M, CCPI, and IP.

Note 3: Model 1: no intercept and no trend; Model 2: restricted intercept and no trend; Model 3: unrestricted and no trend; Model 4: unrestricted intercept and trend; and Model 5: unrestricted intercept and trend. 
Table B18. Short-run Regression for MGB3Y, with CETES1M, CCPI, and IP

\begin{tabular}{|c|c|c|c|c|c|}
\hline & Model 1 & Model 2 & Model 3 & Model 4 & Model 5 \\
\hline \multicolumn{6}{|l|}{ Speed of adjustment } \\
\hline MGB3Y(-1) & $\begin{array}{c}-0.026 \\
(0.0390)\end{array}$ & $\begin{array}{l}-0.207^{* *} \\
(0.0709)\end{array}$ & $\begin{array}{l}-0.207^{* *} \\
(0.0709)\end{array}$ & $\begin{array}{c}-0.067 \\
(0.1030)\end{array}$ & $\begin{array}{c}-0.067 \\
(0.1030)\end{array}$ \\
\hline \multicolumn{6}{|c|}{ Short-run coefficient } \\
\hline$\Delta \mathrm{MGB} 3 \mathrm{Y}(-1)$ & $\begin{array}{l}-0.247^{*} \\
(0.1110)\end{array}$ & & & $\begin{array}{c}-0.241 \\
(0.1350)\end{array}$ & $\begin{array}{c}-0.241 \\
(0.1350)\end{array}$ \\
\hline$\triangle \mathrm{MGB} 3 \mathrm{Y}(-2)$ & $\begin{array}{c}-0.061 \\
(0.1070)\end{array}$ & & & $\begin{array}{c}-0.061 \\
(0.1220)\end{array}$ & $\begin{array}{c}-0.061 \\
(0.1220)\end{array}$ \\
\hline$\Delta \mathrm{MGB} 3 \mathrm{Y}(-3)$ & $\begin{array}{c}-0.045 \\
(0.1090)\end{array}$ & & & $\begin{array}{c}-0.048 \\
(0.1180)\end{array}$ & $\begin{array}{c}-0.048 \\
(0.1180)\end{array}$ \\
\hline$\triangle \mathrm{MGB} 3 \mathrm{Y}(-4)$ & $\begin{array}{l}-0.257^{*} \\
(0.1060)\end{array}$ & & & $\begin{array}{l}-0.276^{*} \\
(0.1140)\end{array}$ & $\begin{array}{c}-0.276^{*} \\
(0.1140)\end{array}$ \\
\hline$\Delta$ MGB3 Y $(-5)$ & $\begin{array}{c}0.095 \\
(0.1050)\end{array}$ & & & $\begin{array}{c}0.066 \\
(0.1080)\end{array}$ & $\begin{array}{c}0.066 \\
(0.1080)\end{array}$ \\
\hline$\Delta \mathrm{MGB} 3 \mathrm{Y}(-6)$ & $\begin{array}{c}-0.076 \\
(0.1040)\end{array}$ & & & $\begin{array}{c}-0.094 \\
(0.1090)\end{array}$ & $\begin{array}{c}-0.094 \\
(0.1090)\end{array}$ \\
\hline$\Delta \mathrm{MGB} 3 \mathrm{Y}(-7)$ & $\begin{array}{l}-0.239^{*} \\
(0.1040)\end{array}$ & & & $\begin{array}{c}-0.258^{*} \\
(0.1110)\end{array}$ & $\begin{array}{c}-0.258^{*} \\
(0.1110)\end{array}$ \\
\hline$\triangle \mathrm{MGB} 3 \mathrm{Y}(-8)$ & $\begin{array}{l}-0.228^{*} \\
(0.1060)\end{array}$ & & & $\begin{array}{l}-0.248^{*} \\
(0.1110)\end{array}$ & $\begin{array}{c}-0.248^{*} \\
(0.1110)\end{array}$ \\
\hline$\triangle$ CETES1M & $\begin{array}{l}0.445^{* * *} \\
(0.1300)\end{array}$ & $\begin{array}{c}0.334^{*} \\
(0.1280)\end{array}$ & $\begin{array}{c}0.334^{*} \\
(0.1280)\end{array}$ & $\begin{array}{c}0.393^{* *} \\
(0.1400)\end{array}$ & $\begin{array}{c}0.393^{* *} \\
(0.1400)\end{array}$ \\
\hline$\Delta$ CETES1M(-1) & $\begin{array}{c}0.337^{*} \\
(0.1370)\end{array}$ & & & $\begin{array}{c}0.296^{*} \\
(0.1420)\end{array}$ & $\begin{array}{c}0.296^{*} \\
(0.1420)\end{array}$ \\
\hline Trend & & & & & $\begin{array}{c}0.003^{*} \\
(0.0013)\end{array}$ \\
\hline Constant & & & $\begin{array}{c}0.501^{*} \\
(0.2050)\end{array}$ & $\begin{array}{c}-0.148 \\
(0.3170)\end{array}$ & $\begin{array}{c}-0.148 \\
(0.3170)\end{array}$ \\
\hline$N$ & 102 & 102 & 102 & 102 & 102 \\
\hline Adj. $R^{2}$ & 0.194 & 0.141 & 0.141 & 0.216 & 0.216 \\
\hline
\end{tabular}

Note 1: Standard errors in parentheses, ${ }^{*} p<0.05,{ }^{* *} p<0.01,{ }^{* * *} p<0.001$.

Note 2: Dependent variable is MGB3Y and independent variables are CETES1M, CCPI, and IP.

Note 3: Model 1: no intercept and no trend; Model 2: restricted intercept and no trend; Model 3: unrestricted and no trend; Model 4: unrestricted intercept and trend; and Model 5: unrestricted intercept and trend. 